Prepared in cooperation with the Nooksack Indian Tribe

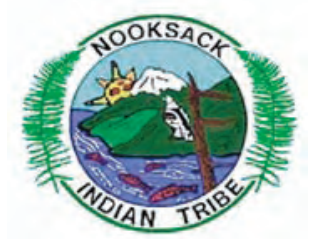

\title{
Ground Water/Surface Water Interactions and Quality of Discharging Ground Water in Streams of the Lower Nooksack River Basin, Whatcom County, Washington
}
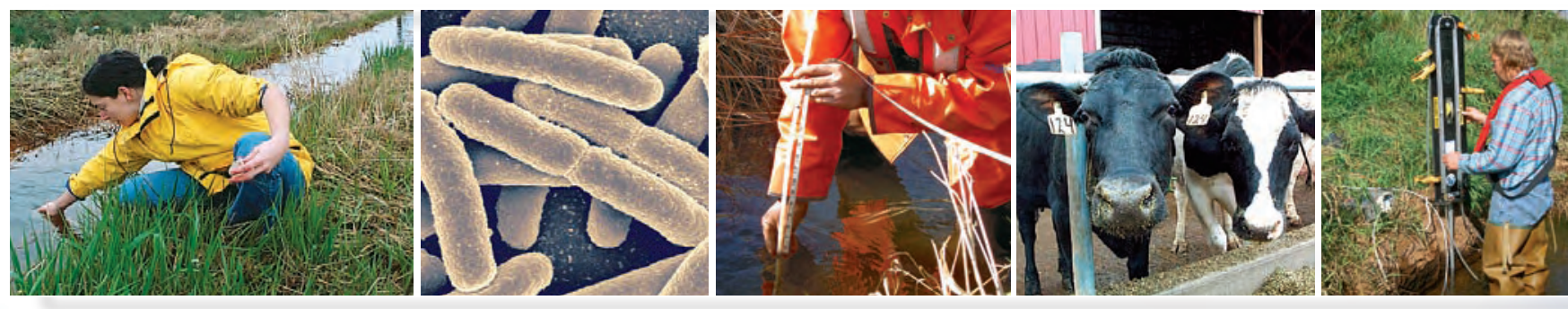

- Seientific Investigations Report 2005-5255 
Cover: Photograph of Fishtrap Creek, spring 2004. (Photograph taken by Stephen E. Cox, U.S. Geological Survey, 2004.)

Inset 1: Photograph of hydrologist collecting surface-water sample. (Photograph taken by F. William Simonds, U.S. Geological Survey, 2003.)

Inset 2: Scanning electron microscope image of E. colicells. (Photograph from Rocky Mountain Laboratory; National Institute of Allergy and Infectious Diseases; National Institute of Health.) Inset 3: Photograph showing comparison of ground-water and surface-water levels. (Photograph taken by Stephen E. Cox, U.S. Geological Survey, 2003.)

Inset 4: Photograph of Holstein dairy cows. (Photograph taken by F. William Simonds, U.S. Geological Survey, 2003.)

Inset 5: Photograph of manometer board showing measurements of vertical hydraulic gradient

(Photograph taken by Stephen E. Cox, U.S. Geological Survey, 2003.) 


\section{Ground Water/Surface Water Interactions and Quality of Discharging Ground Water in Streams of the Lower Nooksack River Basin, Whatcom County, Washington}

By Stephen E. Cox, U.S. Geological Survey; F. William Simonds,U.S. Geological Survey; Llyn Doremus, Nooksack Indian Tribe; Raegan L. Huffman, U.S. Geological Survey; and Rose M. Defawe, U.S. Geological Survey

Prepared in cooperation with the Nooksack Indian Tribe

Scientific Investigations Report 2005-5255 


\section{U.S. Department of the Interior \\ Gale A. Norton, Secretary \\ U.S. Geological Survey \\ P. Patrick Leahy, Acting Director}

U.S. Geological Survey, Reston, Virginia: 2005

For sale by U.S. Geological Survey, Information Services
Box 25286, Denver Federal Center
Denver, CO 80225
For more information about the USGS and its products:
Telephone: 1-888-ASK-USGS
World Wide Web: http://www.usgs.gov/

Any use of trade, product, or firm names in this publication is for descriptive purposes only and does not imply endorsement by the U.S. Government.

Although this report is in the public domain, permission must be secured from the individual copyright owners to reproduce any copyrighted materials contained within this report.

Suggested citation:

Cox, S.E., Simonds, F.W., Doremus, Llyn, Huffman, R.L., and Defawe, R.M., 2005, Ground water/surface water interactions and quality of discharging ground water in streams of the lower Nooksack River Basin, Whatcom County, Washington: U.S. Geological Survey Scientific Investigations Report 2005-5255, 46 p. 


\section{Contents}

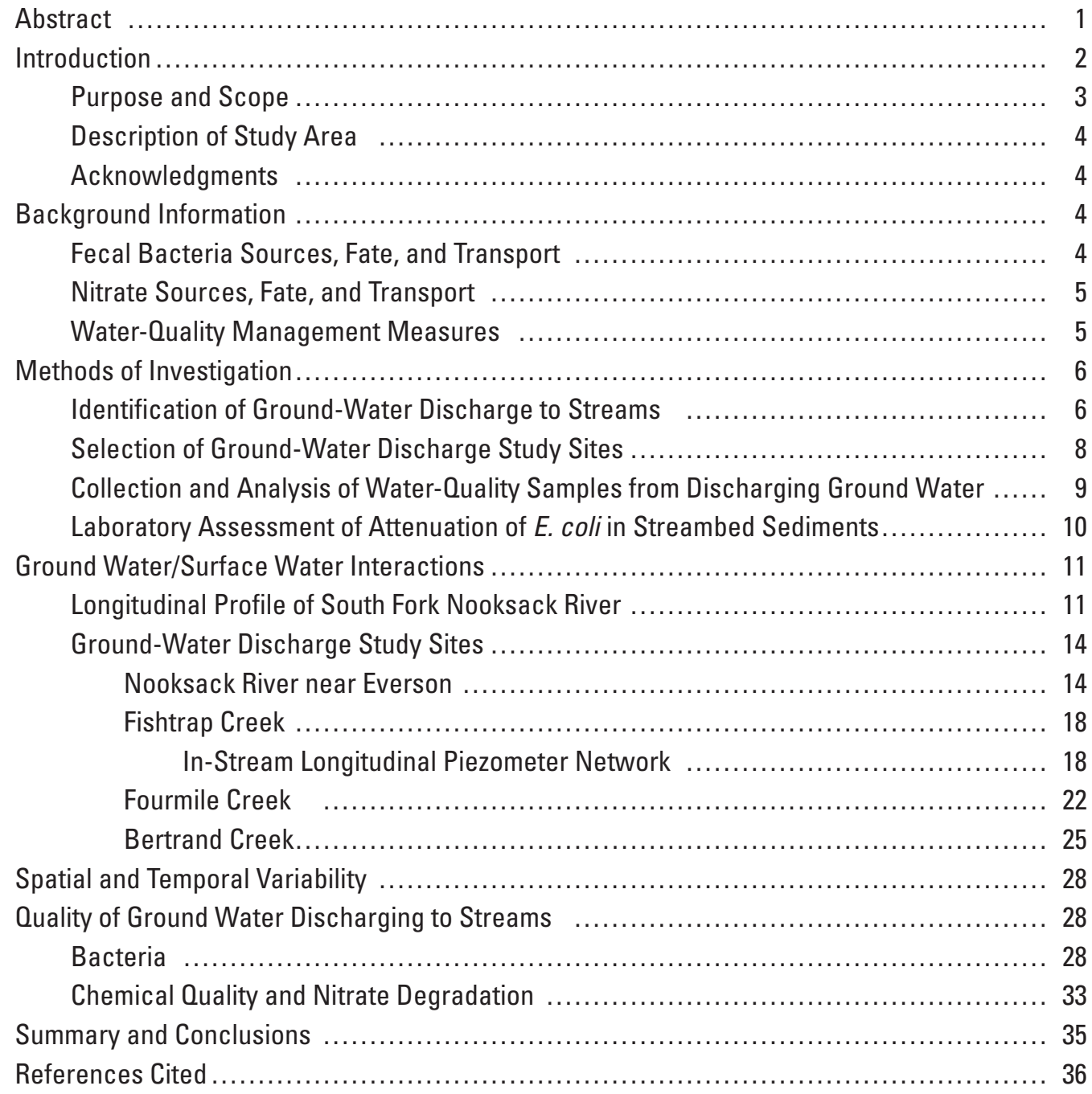




\section{Figures}

Figure 1. Map showing location of four ground-water discharge study sites, monitoring network sites on Fish Trap Creek, monitoring well ABS-480, and reach of thermal profile on South Fork Nooksack River in the lower Nooksack River basin, Whatcom County, Washington

Figure 2. Diagram showing how a manometer board is used to directly measure hydraulic head differences across a streambed and compute vertical hydraulic gradients

Figure 3. Photograph showing microcosm chamber used in sediment bacteria attenuation study

Figure 4. Thermal profile of the South Fork Nooksack River, Whatcom County, Washington, August 28, 2003

Figure 5. Map showing generalized surficial geology and location of reaches of discharging ground water, South Fork Nooksack River, Whatcom County, Washington

Figure 6. Aerial photographs showing oblique view and thermal image from Forward Looking Infrared Radar (FLIR) of the detailed ground-water study site at the Nooksack River 2 miles south of Everson, lower Nooksack River basin, Whatcom County, Washington

Figure 7. Hydrographs showing continuous water-level and vertical hydraulic gradient data and temperatures of surface water and ground water at the Nooksack River near Everson, Whatcom County, Washington, 2002-04

Figure 8. Map showing location of vertical hydraulic gradient monitoring network, and ground-water discharge study site on Fishtrap Creek, lower Nooksack River basin, Whatcom County, Washington

Figure 9. Graph showing seasonal variations in vertical hydraulic gradients in ground water beneath the streambed of Fishtrap Creek, from the Canadian border to the confluence with the Nooksack River, Whatcom County, Washington, September 2002-July 2004

Figure 10. Graphs showing seasonal variations in vertical hydraulic gradients in ground water beneath the streambed measured at two piezometer transects across Fishtrap Creek, lower Nooksack River basin, Whatcom County, Washington, October 2003 to May 2004

Figure 11. Hydrographs showing continuous water level and vertical hydraulic gradient data and temperatures of surface water and ground water at Fishtrap Creek at Pangborn Road, lower Nooksack River basin, Whatcom County, Washington, March 2003 to October 2004

Figure 12. Graphs showing seasonal variations in vertical hydraulic gradients in ground water beneath the streambed measured at two piezometer transects across Fourmile Creek, lower Nooksack River basin, Whatcom County, Washington, February to May 2004 


\section{Figures-Continued}

Figure 13. Hydrographs showing continuous water level and vertical hydraulic gradient data and temperatures of surface water and ground water at Fourmile Creek near Guide Meridian, lower Nooksack River basin, Whatcom County, Washington, December 2003 to October 2004

Figure 14. Graphs showing seasonal variations in vertical hydraulic gradients in ground water at three piezometer transects across a drainage ditch tributary of Bertrand Creek, lower Nooksack River basin, Whatcom County, Washington, October 2003 to June 2004

Figure 15. Hydrographs showing continuous water level and vertical hydraulic gradient data and temperatures of surface water and ground water at a tributary to Bertrand Creek, lower Nooksack River basin, Whatcom County, Washington, April to October 2004

Figure 16. Boxplot showing concentrations of $E$. coli in surface water and discharging ground water of the Nooksack River lowland, Whatcom County, Washington

Figure 17. Scatterplot showing concentrations of E. coli in surface water and discharging ground water from network piezometers along Fishtrap Creek, lower Nooksack River basin, Whatcom County, Washington

Figure 18. Photographs showing Fishtrap Creek at normal flow and overbank flow during the October 19, 2003, precipitation event, lower Nooksack River basin, Whatcom County, Washington

Figure 19. Graph showing concentration and rate of attenuation of E. coli in stream sediments amended with dairy manure.

Figure 20. Scatterplot showing nitrate and ferrous iron concentrations in discharging ground water, lower Nooksack River basin, Whatcom County, Washington

Figure 21. Graph showing dissolved argon and nitrogen concentrations in discharging ground water, lower Nooksack River basin, Whatcom County, Washington

\section{Tables}

Table 1. Ground-water and surface-water quality data for samples collected at the Nooksack River near Everson, lower Nooksack River basin, Whatcom County, Washington, February 2003 to September 2004.

Table 2. Ground-water and surface-water quality data for samples collected at Fishtrap Creek, lower Nooksack River basin, Whatcom County, Washington, October 2003 to September 2004

Table 3. Ground-water and surface-water quality data for samples collected at Fourmile Creek, lower Nooksack River basin, Whatcom County, Washington, March 2004 to October 2005

Table 4. Ground water and surface water quality data for samples collected at the tributary to Bertrand Creek, lower Nooksack River basin, Whatcom County, Washington, September 2003 to October 2004 


\section{Conversion Factors and Datums}

Conversion Factors

Inch/Pound to SI

\begin{tabular}{lcl}
\hline \multicolumn{1}{c}{ Multiply } & By & \multicolumn{1}{c}{ To obtain } \\
\hline acre & 0.4047 & hectare \\
inch (in.) & 2.54 & centimeter \\
inch (in.) & 25.4 & millimeter \\
inch per year (in/yr) & 25.4 & millimeter per year \\
foot (ft) & 0.3048 & meter \\
mile (mi) & 1.609 & kilometer \\
square mile $\left(\mathrm{mi}^{2}\right)$ & 2.590 & square kilometer \\
cubic foot per second $\left(\mathrm{ft}^{3} / \mathrm{s}\right)$ & 0.02832 & cubic meter per second \\
foot per mile $(\mathrm{ft} / \mathrm{mi})$ & 0.1894 & meter per kilometer \\
\hline
\end{tabular}

Water temperature in degrees Celsius $\left({ }^{\circ} \mathrm{C}\right)$ may be converted to degrees Fahrenheit $\left({ }^{\circ} \mathrm{F}\right)$ as follows:

$$
{ }^{\circ} \mathrm{F}=\left(1.8 x^{\circ} \mathrm{C}\right)+32
$$

SI to Inch/Pound

\begin{tabular}{lll}
\hline \multicolumn{1}{c}{ Multiply } & By & \multicolumn{1}{c}{ To obtain } \\
\hline centimeter $(\mathrm{cm})$ & 0.3937 & inch \\
cubic centimeter $\left(\mathrm{cm}^{3}\right)$ & 0.06102 & cubic inch \\
gram $(\mathrm{g})$ & 0.03527 & ounce, avoirdupois \\
millimeter $(\mathrm{mm})$ & 0.03937 & inch \\
meter $(\mathrm{m})$ & 3.281 & foot \\
\hline
\end{tabular}

Datums

Vertical coordinate information is referenced to the North American Vertical Datum of 1988 (NAVD 88).

Horizontal coordinate information is referenced to the North American Datum of 1983 (NAD 83). Altitude, as used in this report, refers to distance above the vertical datum. 


\title{
Ground Water/Surface Water Interactions and Quality of Discharging Ground Water in Streams of the Lower Nooksack River Basin, Whatcom County, Washington
}

\author{
By Stephen E. Cox', F. William Simonds', Llyn Doremus², Raegan L. Huffman', and Rose M. Defawe ${ }^{1}$
}

\begin{abstract}
Widespread and persistent elevated concentrations of fecal bacteria and nitrate have been documented in lowland stream waters of the Nooksack River basin, Whatcom County, Washington. The application of large quantities of livestock manures to fields and pastures overlying a shallow and highly permeable aquifer has resulted in elevated fecal-bacteria concentrations in surface waters and high nitrate concentrations in ground water. Because of the high permeability of the shallow aquifer and the persistence of fecal bacteria in surface waters during the late summer baseflow period, discharging ground water may be a source of bacteria in stream water analyzed from this area. In this study, spatial and temporal variations in ground-water discharge were characterized, and water-quality analyses and laboratory experiments were conducted to better understand the processes that control the transport and fate of these contaminants at the interface between ground water and surface water.

Ground-water discharge is nearly continuous at many locations in the Nooksack River lowland except during periods of high river stage or late summer low flow. Ground-water discharge generally is greater during the wet winter months and decreases during the dry summer months. In some cases, the direction of water flow reverses for brief intervals so that surface water recharges ground water. Detailed site studies in various hydrologic settings in the Nooksack River lowland show small local-scale spatial variations and large temporal variations in ground-water discharge. Locations of groundwater discharges appear to be related to the distribution of permeable geologic materials adjacent to the streambed.
\end{abstract}

Samples of discharging ground water collected from the shallow sediments beneath streams and rivers rarely contained measurable concentrations of the fecal bacteria Escherichia coli or nitrate, indicating that ground-water transport was not a major source of bacteria and nitrate to surface waters of the reaches that were studied. In samples of ground-water discharge from most study sites, concentrations of dissolved oxygen typically were less than 1 milligram per liter and concentrations of dissolved ferrous iron typically ranged from 0.1 to 17 milligrams per liter. These geochemical oxidation-reduction (redox) conditions in ground water within the monitored reaches are conducive to denitrification. Concentrations of dissolved argon and nitrogen gas measured in discharging ground water indicate that 5 to 15 milligrams per liter of nitrate were denitrified prior to its discharge to surface water.

A laboratory microcosm experiment was used to evaluate the potential for high bacteria concentrations measured in streamflow during late summer periods that may have originated from field sediments washed into streams during preceding wintertime overbank flow events. The microbial attenuation experiment, conducted with manure amended native stream sediment, showed that less than 1 percent of fecal coliform bacteria survived beyond 65 days and that at 100 days the sediment coliform concentration had attenuated to near pre-amendment levels. Although small numbers of bacteria remained viable in sediments at the end of the experiment, it is unlikely that enough bacteria survive the many months between winter and summer to make up the substantial fraction of large fecal coliform concentrations measured during late summer.

\footnotetext{
${ }^{1}$ U.S. Geological Survey.

2 Nooksack Indian Tribe.
} 


\section{Introduction}

A series of studies have documented the occurrence of elevated concentrations of fecal bacteria and nitrate in lowland streams of Whatcom County, Washington. These and other water-quality issues have created significant challenges for water-resources managers in the lower Nooksack River basin of Whatcom County (fig. 1). Because additional sources of fresh water are not readily available in this area, balancing the competing demands for water resources in this region is of great concern to the public and a high priority to local waterresources managers. In addition, water-resource allocations have been implemented by State regulation of instream flows (Chapter 173-501 WAC) as a result of the Endangered Species Act and the listing of Chinook salmon and Bull trout as "threatened species." An improved understanding of how ground water and surface water interact in the area will greatly assist water-resources managers in making decisions that result in improved water quality.
The quality of surface water and ground water in the lower Nooksack River basin has been degraded. Land use is predominantly rural agriculture; however, there is persistent encroachment of residential development from nearby population centers. The Washington State Department of Ecology maintains a list of impaired waters as directed under the Clean Water Act section 303(d). The 1998 303(d) list is the most recent list approved by the Environmental Protection Agency and includes numerous stream reaches in the lower Nooksack River basin that are listed primarily for fecal coliform contamination. In streams that have been intensively monitored, elevated fecal coliform and nitrate concentrations occur throughout the year (Embrey and Frans, 2003). Nitrate contamination of ground water is widespread in the shallow glacial aquifer, which supplies drinking and irrigation water for about 60,000 people (Kaluarachchi and Almasri, 2002). Although precipitation is plentiful in this region, it occurs unevenly throughout the year, resulting in winter-time periods of standing water and summer-time periods of soil-moisture deficits. During the summer low-flow periods, available

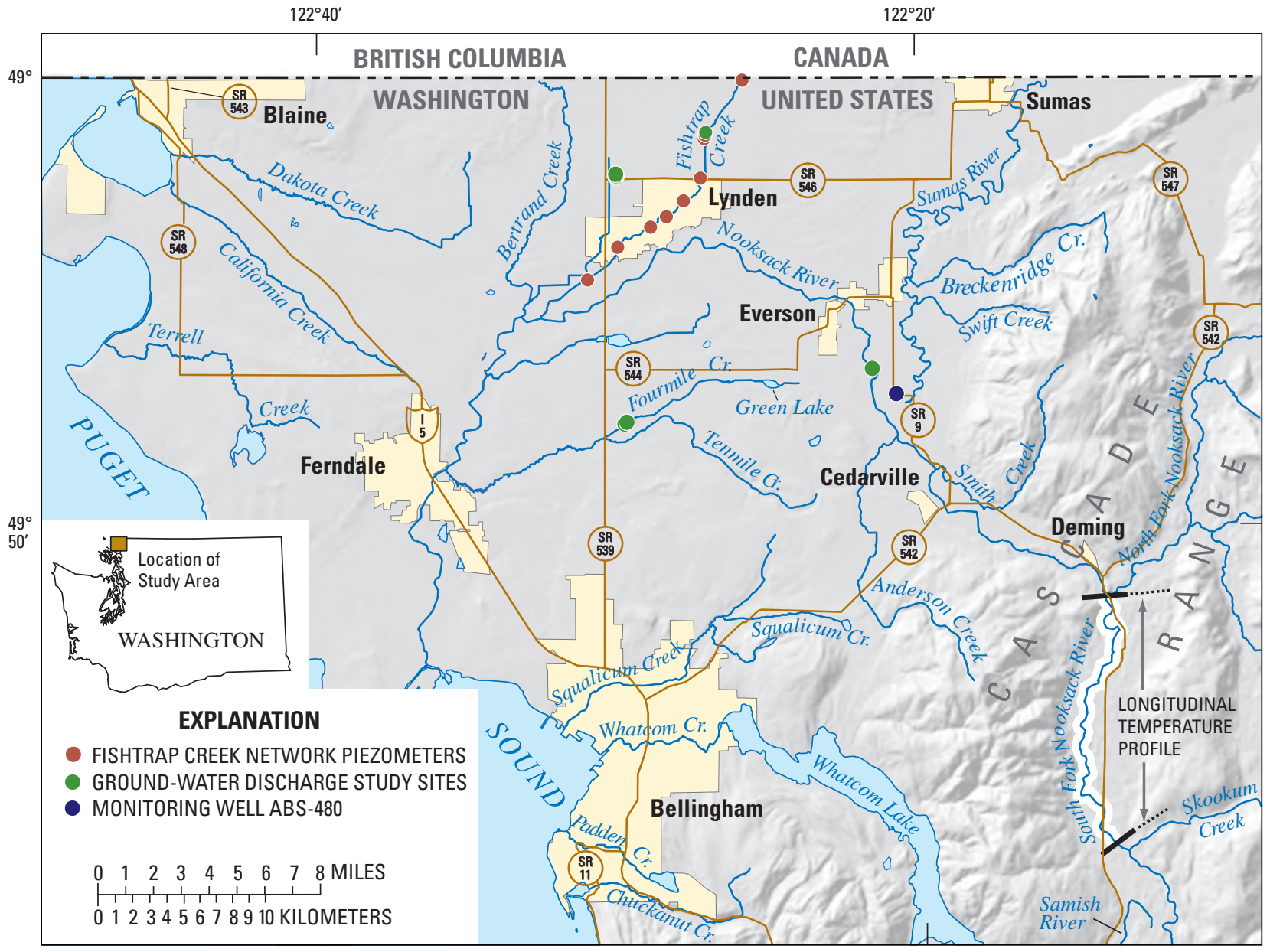

Figure 1. Location of four ground-water discharge study sites, monitoring network sites on Fish Trap Creek, monitoring well ABS-480, and reach of thermal profile on South Fork Nooksack River in the lower Nooksack River basin, Whatcom County, Washington. 
surface water is insufficient to meet demands for agricultural crop irrigation, potable water supplies, and maintenance of in-stream flows for fish habitat.

Recent monitoring shows the widespread occurrence of fecal coliform bacteria in lowland streams (Embrey, 2001; Northwest Indian College, 2004). The human health hazards associated with fecal coliform exposure have resulted in the closures of shellfish beds in Puget Sound near Bellingham and the posting of warnings at recreational areas. The economic impact of such closures has focused attention on various sources of contamination. Previous studies (Erickson, 1995; Joy, 2000) did not conclusively establish a link between the concentration of fecal coliform in the mainstem of the Nooksack River, and the corresponding streamflow-discharge response due to rainfall-runoff events. These studies found that the concentrations of fecal coliform did not decrease along the downstream length of the river, suggesting that either attenuation of fecal coliform was not occurring or that there was a persistent source of fecal coliform along the length of the river. This lead to the hypothesis that ground water may be a source of fecal coliform in lowland streams during the late summer base-flow period, when discharging ground water is the primary source of water in those streams. Alternatively, manure application practices, overland flow, and discharge from tile drains also may provide significant pathways for transport of bacteria to surface water. These alternate pathways and their relative importance need to be better understood for effective management measures to improve surface-water and ground-water quality.

Discharging ground water that provides nutrients to streams also is of concern to water managers and local residents. Nutrients in discharging ground water could lead to excessive in-stream plant growth and biomass production that in turn leads to high biological and chemical oxygen demands, which depletes dissolved oxygen available for fish and other aquatic organisms. Numerous studies have documented concentrations of nitrate as nitrogen in ground water consistently greater than $10 \mathrm{mg} / \mathrm{L}$ in parts of Whatcom County. Nitrate contamination is extensive and present to some extent in virtually all parts of the surficial aquifers of the Nooksack River lowland (Garland and Erickson, 1994; Inkpen and others, 2000; Kaluarachchi and Almasri, 2002) and British Columbia (Liebscher and others, 1992; Gartner-Lee, 1993; Hii and others, 1999). Concentrations of nitrate as nitrogen greater than $10 \mathrm{mg} / \mathrm{L}$ exceed the U.S. Environmental Protection Agency drinking-water standard and thus limit the suitability of ground water for use as a source of domestic and municipal water supply.

Nitrate concentrations in ground water have been steadily increasing in many parts of the study area for more than 20 years (Kaluarachchi and Almasri, 2002). They are expected to continue to increase because the application of fertilizer and manure in Whatcom County has increased as much as 50-fold since 1945. Manure application to forage production fields that are part of farm nutrient management plans supplies a major, long-term source of nitrates in ground water (Carey, 2002). More than 20 percent of water supply wells sampled in the Sumas-Blaine aquifer (Erickson, 1998) contained nitrate concentrations that exceeded the U.S. Environmental Protection Agency $10 \mathrm{mg} / \mathrm{L}$ standard for drinking water supplies. The effectiveness of management strategies in the reduction of nitrate in ground water would benefit from a more detailed understanding of the processes affecting fate and transport of nitrate in the lower Nooksack River basin.

\section{Purpose and Scope}

This report describes the results of a study to:

1. Improve the understanding of the interaction between surface water and ground water in the shallow glacial aquifer of the lower Nooksack River basin by monitoring spatial and temporal variations in vertical hydraulic gradient near the ground water/surface water interface;

2. Evaluate if fecal bacteria present in manure applied to fields adjacent to stream channels is being transported to the stream channels through shallow ground-water pathways; and

3. Evaluate the fate of nitrate present in ground water of the lower Nooksack River basin as it discharges into the surface-water system.

Knowledge gained from this study is expected to enable more effective management and implementation of measures designed to decrease nitrate and fecal-bacteria concentrations in ground water and prevent contamination from reaching surface water. The specific objectives of this study are to:

1. Identify reaches in selected streams where ground water naturally discharges through the streambed and monitor the spatial and temporal variations of these discharges;

2. Determine if fecal bacteria and nitrate are discharged from ground water to surface water in selected stream reaches at regular seasonal intervals or during significant rainfall events and through tile drain discharge; and

3. Evaluate the extent of nitrate degradation that occurs in discharging ground water to streams.

An additional objective was added after reconnaissance sampling indicated that little if any fecal bacteria concentrations would be present in discharging ground water. This additional objective was to determine the attenuation or rate of die-off of fecal bacteria associated with the surfacewater bed sediments. 


\section{Description of Study Area}

The Nooksack River lowland encompasses the area from the Cascade foothills to the Puget Sound and from Bellingham to the Canadian border (fig. 1). Surface features within this lowland area include glacial outwash plains, hummocky uplands, and alluvial flood plains (Cox and Kahle, 1999). Two major forks of the Nooksack River join near the town of Deming where the mainstem of the Nooksack River emerges from the foothills of the Cascade Range to flow across the lowland. The Nooksack River has eroded and cut down through the glacial outwash plain as it flows generally westward toward the Puget Sound. Numerous tributary streams drain the lowland area and flow into the Nooksack River at various points.

The principal aquifer in the lower Nooksack River basin is the Sumas aquifer, which provides water for residential, agricultural, and industrial needs (Cox and Kahle, 1999). This highly productive surficial aquifer formed by glacial outwash streams is composed primarily of extensive deposits of stratified sand and gravel which often contain localized lenses of mixed gravel, sand, silt, and clay. More recent alluvial deposits of the Nooksack and Sumas Rivers cover portions of the glacial outwash plain. Ground water in the Sumas aquifer readily interacts with streams and serves as an important source of summer time streamflow.

The regional climate is strongly influenced by the onshore flow of Pacific marine air, resulting in warm, dry summers and mild, rainy winters. Precipitation within the lowland is variable and ranges from about $32 \mathrm{in} / \mathrm{yr}$ in the southwest part of the lowland to more than $60 \mathrm{in} / \mathrm{yr}$ near the Canadian border. Most precipitation falls as rain during the winter months from October to April. Soils in the area range from well-drained to poorly drained. Surface-drainage ditches and subsurface tile drains have been installed in many areas to allow greater agricultural use of the land. Land use is predominantly agricultural with dairy production occupying roughly 57,600 acres with a total of about 60,000 cows. Livestock manure typically is stored in lagoons and applied to farm fields in the dryer summer months between April and September as per county ordinance.

\section{Acknowledgments}

This study was conducted with the assistance of many individuals and organizations. We thank Ryan Kopp of the Nooksack Indian Tribe, George Swanasett Jr, and Lynn VanWierengen of Washington State University for assistance in field work and data collection. We also thank private land and well owners in the study area who allowed us access to sampling sites.

\section{Background Information}

\section{Fecal Bacteria Sources, Fate, and Transport}

Fecal bacteria are present in the intestinal tract and feces of warm-blooded animals, some of which can cause diseases in humans, such as cholera and dysentery when spread as waterborne pathogen originating in sewage from infected humans (Craun, 1986). Because fecal coliforms can be readily detected in water samples and are present in untreated human sewage, their presence in samples of surface water is considered an indicator of the potential presence of other pathogenic bacteria species that can occur in human sewage and are not easily detected. Escherichia coli (E. coli) is a major component of the fecal coliform bacteria group and typically are harmless to humans. In recent years however, several atypical strains of $E$. coli have been identified that are linked to a variety of diseases in humans, most notable being the strain E. coli $(\mathrm{O} 157: \mathrm{H} 7)$ that cause hemorrhagic colitis (Nataro and Kaper, 1998). Cattle have been shown to be a reservoir for E. coli O157:H7 (Hancock and others, 1994; Hussein and Sakuma, 2005) and while most recorded outbreaks of E. coli $\mathrm{O} 157: \mathrm{H} 7$ infections have resulted from consumption of contaminated food products or contact with farm animals, manure handling and contact with contaminated surface waters are considered potential routes of E. coli O157: H7 infection in humans (Petridis and others, 2002).

Most area residents living outside of the towns of Lynden and Everson use on-site septic systems to treat domestic sewage. Livestock farms in the lower Nooksack River basin generate large quantities of manure and use various disposal methods including manure application to pasturelands and croplands either by direct application, field spraying, or direct injection below the soil surface. Direct injection reduces the potential for surface runoff to transport bacteria from agricultural fields to surface water. However, this method also enhances the likelihood that viable bacteria are transported to shallow aquifers by eliminating exposure of fecal bacteria to the sterilizing effects of oxygen and sunlight and reducing the distance of the pathway from land surface to the shallow aquifer.

The potential for fecal bacteria to occur in ground water is governed by the quantity of bacteria (manure application) deposited on agricultural fields, the infiltration capacity and rate of transport through the shallow subsurface soils, and the fate and transport of the bacteria once they have entered the aquifer. Die-off of bacterial cells and filtration within sediment pore spaces reduce bacteria concentrations as water flows through porous media (Bitton and Harvey, 1992), reducing the number of organisms that are transported to, and remain viable in ground water. 
Subsurface tile drains in many fields of the lower Nooksack River basin increase the discharge rate of shallow ground water to surface water and lower the water-table elevation early in the year thereby allowing earlier spring planting and extending the growing season. In similar agricultural settings, subsurface tile drains have been shown to be a significant pathway for fecal coliform transport to adjacent surface-water streams (Patni and others, 1984; Joy and others, 1998).

\section{Nitrate Sources, Fate, and Transport}

The accumulation of nitrate in ground water primarily is dependent on the input of nitrogen and the presence or absence of oxygen. Nitrogen is applied to agricultural production fields primarily as ammonium in fertilizer or as a component of barnyard manure. Within aerobic soils, ammonium is converted to nitrate by nitrifying bacteria. Nitrate dissolves easily, and remains stable in water under aerobic conditions. Nitrate is transported with infiltrating soil water and if not assimilated by plants within the soil-root zone, nitrate is leached to the underlying ground-water system. Nitrate does not react readily with aquifer materials and remains in ground water throughout the ground-water flow path unless utilized by denitrifying microbes. Attenuation of elevated nitrate concentrations in ground water can occur under chemically reducing conditions by microbially mediated processes if sufficient carbon is available (Korom, 1992). Facultative denitrifying microbes that are capable of this process generally are present throughout most surficial aquifers (Chapelle, 1993).

Much of the Sumas aquifer typically is aerobic and contains limited organic carbon (Cox and Kahle, 1999) and thus may not be widely conducive to nitrate degradation by microbial processes. Geochemical conditions that support nitrate degradation are clearly present in some parts of the aquifer (Tesoriero and others, 2000) as well as in some soils and near the water table (Carey, 2002). Tesoriero and others (2000) observed nitrate degradation in carbon rich sediments adjacent to a stream in the lower Nooksack River basin and postulated that in other parts of the aquifer, iron minerals also might be used for denitrification. In locations where anaerobic conditions are present along with a suitable source of electrons, these naturally occurring facultative denitrifying bacteria can reduce nitrate to nitrogen gas.

\section{Water-Quality Management Measures}

There have been extensive efforts over many years to develop and implement farm-management practices that reduce migration of contaminants from farms to the surrounding environment. Local and State efforts to reduce the agricultural loading of nitrate to ground water and fecal bacteria to surface water are supported by regulatory requirements that are intended to bring water bodies into compliance with the Clean Water Act standards. Whatcom County adopted a Manure Control Ordinance in 1998 that restricts the field application of manure for forage production to April through September. The Washington State Department of Ecology has developed and is currently implementing a Total Maximum Daily Load Detailed Implementation Plan for reduction of fecal bacteria in surface-water drainages. A consortium of local governmental agencies is currently developing watershed-scale models within a decision-support system to increase water-resources management capabilities of local decisionmakers. A smaller-scale nitrate ground-water transport model is currently being developed by Environment Canada in coordination with Simon Fraser University for the trans-boundary Abbotsford-Sumas aquifer. This is relevant to the lower Nooksack River basin efforts because the headwaters of some of the northernmost tributaries to the Nooksack River (Bertrand and Fishtrap Creeks) lie in Canada. In addition, the direction of ground-water flow trends southward toward the Nooksack River transporting nitrogen in ground water across the border, and contributing to the high nitrate concentrations measured at some locations in the United States. Due to a lack of field data, the specific mechanisms describing the fate and transport of nitrate and nitrate degradation in the models being developed are based on assumptions.

Washington State mandated the development of Nutrient Management Plans for all dairy farming operations that handle more than 700 mature dairy cattle under their delegated Clean Water Act authority. These plans require an on-farm nitrogen budget that accounts for the production, distribution, and plant and animal uptake of nitrogen, so that overall increases in nitrogen concentrations in soil and ground water are avoided. The effectiveness of these and future management strategies in the reduction of nitrate in ground water would benefit from a more detailed understanding of the processes affecting fate and transport of nitrate in the study area. 


\section{Methods of Investigation}

Three distinctly different types of data were collected over a range of hydrologic conditions during this investigation. Data needs included (1) identification and monitoring of areas of ground-water discharge; (2) collection of water-quality samples of discharging ground water prior to interaction with surface water at or near the hyporheic mixing zone; and (3) a laboratory experiment to assess the attenuation of fecal bacteria in sediments from a local stream. Because streams varied in size from small drainage areas to the Nooksack River, various data-collection methods were used that were appropriate to stream size. The small drainage areas included tributary streams (Fishtrap and Fourmile Creeks and a tributary of Bertrand Creek) draining intensive agricultural areas overlying the Sumas aquifer.

\section{Identification of Ground-Water Discharge to Streams}

Determining the locations of ground-water discharge to streams was essential in the evaluation of the quality of discharging ground water. A preliminary assessment of ground-water discharge was conducted to identify areas where ground-water discharges were likely to occur. Existing data used to identify areas of ground-water discharge included miscellaneous measurements of low-flow discharge in lowland streams in Whatcom County in August 2000, and aerial images produced by Forward Looking Infrared Radar (FLIR), taken on August 20, 2001, for about a 60-mile reach of the lower mainstem of the Nooksack River and South Fork Nooksack River (Watershed Sciences, LLC, 2002). The FLIR images showed areas of cooler temperature along the banks of the Nooksack River at some locations indicating the possible presence of discharging ground water.

In addition, a longitudinal temperature profile was conducted along the lower 14-mile reach of the South Fork Nooksack River. The longitudinal temperature profile was developed from a survey of near continuous measurements of stream-water temperatures that were measured near the streambed where discharging ground water would have the greatest influence on stream water temperatures. The survey was conducted during base-flow conditions when average differences between the ground-water and surface-water temperatures exceeded $4^{\circ} \mathrm{C}$. Beginning at the upstream location and preceding in the downstream direction the survey was conducted from a raft carried by the current. A sensor towed along the riverbed recorded data at 2-second intervals for water temperature. A simultaneously recording Global Positioning System (GPS) was used to generate georeferenced data. However, most of the GPS data were corrupted, so field notes and traveltime were used to interpolate between known points. Locations of discharging ground water were identified by changes in slope of the longitudinal temperature profile. This method is described in more detail by Lee and others (1997) and has been successfully applied in the Yakima River (John Vaccaro, U.S. Geological Survey, written commun., 2002).

Ground-water discharge was confirmed by measuring the difference in hydraulic head between the stream and the underlying ground water. Ground-water levels were directly compared to surface-water levels using temporary piezometers and either a manometer board or steel measuring tape. Vertical hydraulic gradients were computed by dividing the difference between the water levels in the stream and the underlying ground water by the depth of the midpoint of the screened interval below the streambed (Winter and others, 1988). Ground-water discharge is indicated when the water level inside the piezometer is higher than the water level of the stream. This condition indicates that the stream is gaining flow, and by convention, the vertical hydraulic gradient is assigned a positive value. In losing stream reaches, the water level in the piezometer is lower than the water level of the stream and the vertical hydraulic gradient is assigned a negative value. The use of the manometer board is shown in figure 2 , and additional details on measurement of vertical hydraulic gradients are presented in Simonds and others (2004).

Temporary in-stream piezometers were installed to measure ground-water levels and to collect water-quality samples of discharging ground water. Piezometers $(\leq 0.5$ in. in diameter) were installed beneath the streambed in areas of calm water away from riffles. Piezometers installed along Fishtrap Creek and the Nooksack River were constructed from a 7-foot length of 0.5-inch-diameter steel pipe in which the end was crimped and perforated with numerous holes roughly $0.063 \mathrm{in}$. in diameter. The piezometer was then driven into the streambed until the perforations were positioned about 3.0 to $6.5 \mathrm{ft}$ below the sediment-water interface to reduce the possibility of sampling surface water from within the hyporheic zone. 


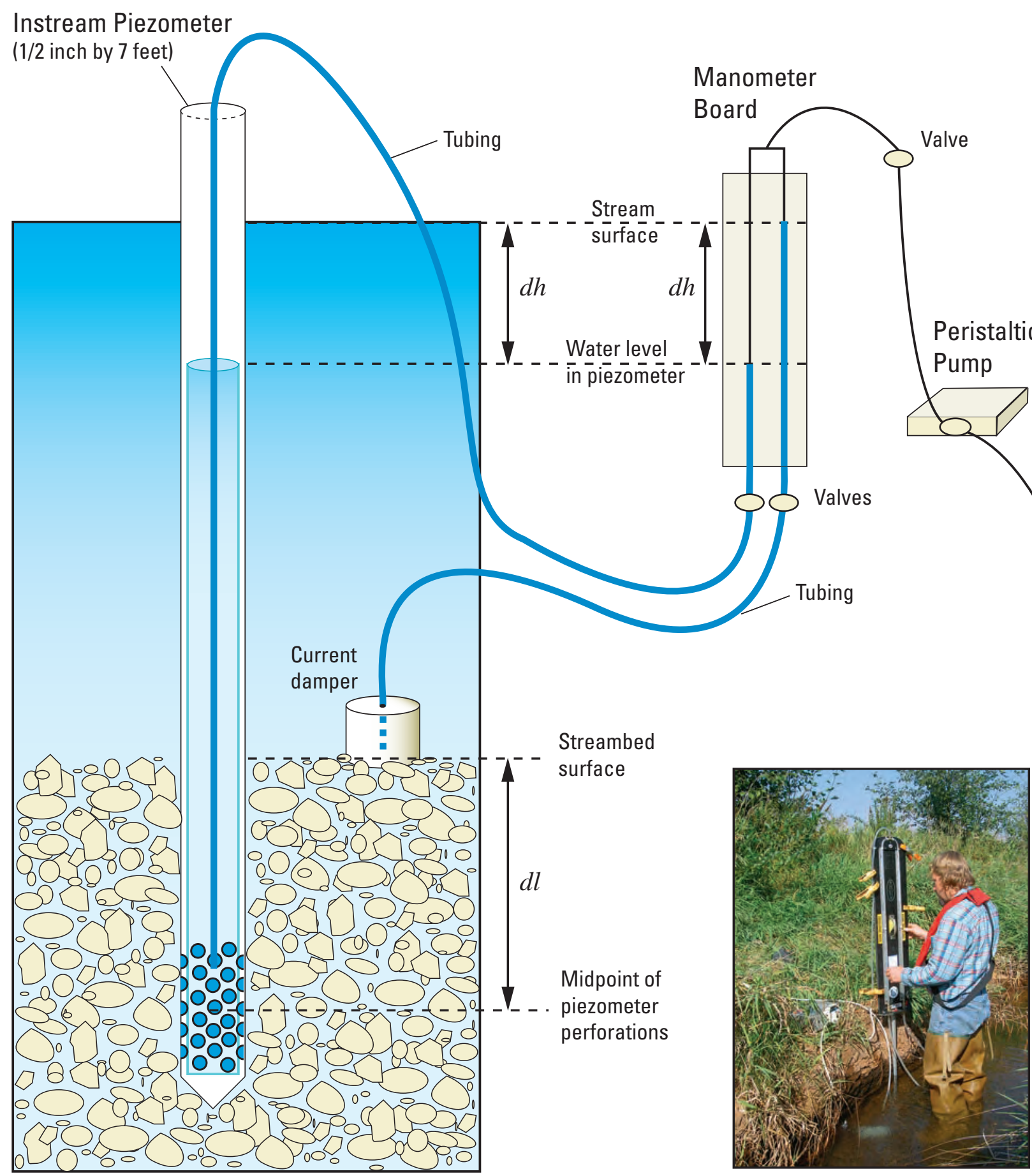

(DIAGRAM NOT TO SCALE)

Manometer board in use

Figure 2. How a manometer board is used to directly measure hydraulic head differences across a streambed and compute vertical hydraulic gradients.

$d h$ is the difference in head (water level) between surface water and ground water. $d l$ is depth below the streambed to the midpoint of piezometer perforations. Vertical hydraulic gradient is determined by dividing $d h$ by $d l$. 
An alternate construction technique was used for installing piezometers at ground-water discharge study sites on Fishtrap and Fourmile Creeks and a tributary to Bertrand Creek. These piezometers were constructed by driving a 0.5 -inch pipe with a loosely fitting plug about $5 \mathrm{ft}$ below the surface. A 6-inch-long stainless-steel screen was attached to a section of 0.375 -inch polyethylene tubing and inserted to the bottom of the pipe. The pipe was then withdrawn in a manner that detached the plug allowing the screen to remain in place as the pipe was removed. Saturated sediment around the polyethylene tubing typically collapsed against the tubing. Bentonite pellets were used to fill the annular space and seal void areas in the unsaturated sediments near the surface. A peristaltic pump was used to flush sediment and turbid water from the screen area and develop communication between the piezometer and the shallow aquifer. Isolation of the ground water and surface water was checked by comparison of water-quality parameters including water temperature, specific conductance, and dissolved oxygen.

Temporary gaging stations were established at each of the four ground-water discharge study sites in order to provide continuous monitoring of surface-water levels, which could be compared with ground-water levels in the underlying shallow aquifer. At each site, a staff plate was installed so that surface-water and ground-water level measurements could be referenced to a common arbitrary datum that was established for each site. Surface-water levels were monitored by installing a 1.25 to 1.5 -inch pipe to house a data logger just above the streambed. Ground-water levels were monitored by installing a similar pipe, fitted with a 6-inch well screen, and driven into the streambed such that the screened interval was 5.0 to $6.5 \mathrm{ft}$ below the streambed. These piezometers also were instrumented with a data logger placed within the screened section. All data loggers used in this study consisted of a selfcontained pressure transducer and temperature thermistor and were set to store readings at 1-hour intervals. All piezometers were vented to the atmosphere and all data were compensated for atmospheric barometric pressure as recorded by a separate data logger placed at the land surface and exposed to the atmosphere. Periodic staff gage readings and physical measurement of ground-water levels were used to confirm the continuous data and make adjustments as necessary.

\section{Selection of Ground-Water Discharge Study Sites}

To characterize the potential range of water-quality responses to the hydrologic system discharging ground water to the streams in the lower Nooksack River basin, four sites were selected for detailed study of ground-water discharge. The specific sites were selected along four different streams based on the presence of discharging ground water. The selected sites represent: (1) a large drainage basin, more than $400 \mathrm{mi}^{2}$ in area, characterized in its lower reaches by flat topography and agricultural land use; (2) a drainage ditch used to control ground-water elevations in an agricultural production field; and (3) two tributary drainages to the mainstem of the Nooksack River, both of which retain a large portion of the natural drainage channel. A major tributary of the Nooksack River, the South Fork Nooksack River, was considered for intensive monitoring, however, a suitable site for investigation of discharging ground water was not found.

Ground-water discharge study sites were selected along reaches of streams where field application of dairy manure was applied to the adjacent fields. One of the sites is located along the Nooksack River about 2 mi upstream of the town of Everson, Washington. This site was selected for continuous monitoring of ground-water and surface-water levels and for the collection of samples of discharging ground water in order to provide data for a high order stream in a large river basin, which encompassed several hundred square miles of drainage area. Fishtrap Creek was selected for study because numerous drainage ditches empty into it creating a complex drainage network. Nine sites with temporary piezometers were established at intervals ranging from 0.6 to $1.6 \mathrm{mi}$ apart along Fishtrap Creek. These sites provided a longitudinal profile along a primary drainage stream in the lower basin. Vertical hydraulic gradients at these sites were measured intermittently over a 2-year period. Ground-water discharge study sites were established at known ground-water discharge areas along Fishtrap and Fourmile Creeks and a tributary ditch to Bertrand Creek. These ground-water discharge study sites were composed of arrays of piezometers arranged in two or three transects of three piezometers each installed perpendicular to the creek. Data from these sites provided detailed information on temporal and spatial distribution of ground-water discharge at an individual field scale. 
The site on the Nooksack River near Everson was selected because ground-water discharge from the bank was indicated in the results of a FLIR survey, which showed cooler temperatures along a portion of the riverbank. Numerous measurements of vertical hydraulic gradient made using the manometer board confirmed the widespread occurrence of discharging ground water at this site. The site also had existing ground-water sampling infrastructure in the adjacent field near the riverbank that provided additional ground-water information. A set of 12, 0.75 inch-diameter, PVC piezometers with a 2-foot-long screened interval had been installed at this site in September 2001. The wells had been installed adjacent to the river and arranged in three transects, each being composed of two well pairs. The transects were aligned perpendicular to the riverbank with the wells located in the field at the top of the bluff_-one pair about $20 \mathrm{ft}$ from the edge of water and the other about $40 \mathrm{ft}$ from the edge of water. Each pair consists of a deep well (25 to $40 \mathrm{ft}$ ) and a shallow well (10 to $15 \mathrm{ft}$ ). Distance along the riverbank between transects was about $500 \mathrm{ft}$. In addition, two continuous multi-channel tubing (CMT) observation wells (EVW-1 and EVW-2) were installed at distances of 0.25 and $0.5 \mathrm{mi}$ from the river in June and August 2004. Each of these wells was installed with 0.1 to 0.2-foot-long open intervals at 9, 27, and $43 \mathrm{ft}$ (well EVW-1) and 12, 27, and $42 \mathrm{ft}$ (well EVW-2),

At the Nooksack River site and each of the other groundwater discharge study sites, a temporary surface-water gaging station was established and instrumented with a data logger in order to assess temporal variability in surface-water levels and water temperature. An in-stream piezometer screened 3 to $5 \mathrm{ft}$ below the sediment-water interface was installed through the riverbed generally within a few feet of the gaging station. The piezometer was instrumented with a data logger to record ground-water levels and water temperature. At the site on the Nooksack River near Everson, ambient ground-water information also was collected by installing a data logger in monitoring well (ABS-480) located about 2 mi southeast of the site (fig. 1).

To assess site-specific spatial variability of ground-water discharge, arrays of piezometers were installed in a series of three (on the right bank, left bank, and center of the channel), forming two or three transects perpendicular to the stream about 50 to $75 \mathrm{ft}$ apart. These transects were established at ground-water discharge study sites on the three smaller streams-Fishtrap, Fourmile, and Bertrand Creeks. Installation of piezometers in these transects facilitated measurement of vertical hydraulic gradient and collection of water samples during all flow conditions, including very high flows (flooding).

\section{Collection and Analysis of Water-Quality Samples from Discharging Ground Water}

Water-quality samples were collected from piezometers at each study site and were analyzed for $E$. coli bacteria and a suite of compounds including nitrate as $\mathrm{N}$, nitrite as $\mathrm{N}$, chloride, excess dissolved nitrogen gas, dissolved organic carbon as $\mathrm{C}$, and ferrous iron. Sterile techniques were used during collection, storage, and analysis of surface-water and ground-water samples for bacterial analysis. Surface-water samples were collected by hand from the midpoint of the stream. Samples were obtained from piezometers using a peristaltic pump with autoclavable silicon tubing. Samples for bacteria analysis were collected into a sterile $250-\mathrm{mL}$ polyethylene bottle and transported on ice to a field laboratory of the U.S. Geological Survey (USGS), Washington Water Science Center, Tacoma, Washington, for processing and incubation within 24 hours of collection.

E. coli was used as the indicator species of fecal contamination as recommended by the U.S. Environmental Protection Agency (2002). Ground-water and surface-water samples analyzed for concentrations of E. coli. (reported as Colony Forming Units per $100 \mathrm{~mL}$ or CFU/100 mL) were enumerated using the enzyme-substrate most-probable number (MPN) enumeration technique (American Public Health Association and others, 1998). This technique was used because it requires less field processing and produces results that are comparable to the membrane filter technique outlined in the USGS National Field Manual for the collection of water-quality data (Myers and Sylvester, 1997).

Quality-assurance samples included blanks, replicates, and positive control samples containing less than 50 cells each of E. coli, Klebsella pneumoniae, and Pseudomonas aeruginosa. The positive control samples were provided by IDEXX Laboratories (Westbrook, Maine). All positive control samples gave the proper enzymatic color change response and resulted in most-probable number concentrations of from 7 to $16 \mathrm{CFU} / 100 \mathrm{~mL}$. E. coli was not detected in any of the field or laboratory blank samples. The relative percentage of difference of duplicate samples ranged from 87 to 315 percent.

In addition to monitoring for bacterial indicators, field measurements of water temperature, specific conductance, dissolved oxygen, and ferrous iron were measured on-site during sample collection. Samples collected for analysis of nitrate and major ions were passed through a $0.45-\mu \mathrm{m}$ membrane filter into polyethylene bottles, chilled, and sent to the USGS National Water Quality Laboratory (NWQL). At the NWQL, samples were analyzed for concentrations of nitrate by colorimetry (Fishman, 1993). Major ions were 
analyzed by ion chromatography described by Fishman and Friedman (1989). In this study, dissolved nitrogen in excess of atmospheric input was used to determine the degree to which biogeochemical breakdown of nitrate was occurring before ground water discharges into the surface-drainage system. Concentrations of dissolved nitrogen and argon were determined by head-space gas chromatography at the USGS Dissolved Gas Laboratory in Reston, Virginia. Water temperature and specific conductance were measured using a temperature compensated probe and meter that was checked daily with a standard reference solution. Dissolved oxygen and ferrous iron measurements were made using CHEMetes colorimetric ampoules (manufactured by CHEMetrics, Inc., Calverton, Va.).

Quality-assurance measures used throughout the study include submitting about 15 percent of samples to the laboratory as quality-assurance samples, which are a combination of replicate and blank samples. Field instruments used in stream reconnaissance and execution of project objectives were calibrated daily with known standards, and temperature recording instruments used throughout the study were compared to standard thermometers during site visits.

\section{Laboratory Assessment of Attenuation of $E$. coli in Streambed Sediments}

The survival of fecal coliform and E. coli in freshwater river and creek sediments was evaluated using a microcosm designed to simulate field conditions of flowing water, diurnal sunlight, and constant water temperature. Field studies utilizing in-stream microcosm chambers were considered but determined to be impractical because sediments could not simultaneously be kept in direct contact with oxygenated streamflow and other conditions that would promote die-off fecal bacteria while at the same time be isolated from potential $E$. coli input from upstream sources. To the extent possible, the laboratory microcosm study simulated field conditions that promote die-off of fecal bacteria within the upper $2 \mathrm{~cm}$ of streambed sediments, including exposure to oxygenated streamflow, sunlight, and water temperature.

In the laboratory study, sediments and water from Fishtrap Creek were collected to construct a continuous flow-open system microcosm (fig. 3). A recirculating pump provided continuously flowing water of $1 \mathrm{~L} / \mathrm{min}$ over a sediment bed that was 1 to $2 \mathrm{~cm}$ in depth. The microcosm was maintained at a constant water temperature $\left(10^{\circ} \mathrm{C}\right)$ and exposed to artificial sunlight for $8 \mathrm{hr} / \mathrm{d}$. Sediment samples for enumeration were a composite of six approximately $1 \mathrm{~cm}^{3}$ subsamples of sediment collected from a randomized grid across the microcosm. E. coli, $\mathrm{pH}$, specific conductance, and dissolved oxygen were monitored in the water overlying sediments during the experiments. Additional details on the microcosm experiment are described in Defawe (2003).

Particle-bound bacteria were dissociated from sediment particles by sonication and enumerated using the membrane filter technique (American Public Health Association and others, 1998). In a series of tests, sonication alone produced the highest and most consistent enumeration results when compared to other procedures that included vortex or stomacher mixing with or without the use of a surfactant (Defawe, 2003). All laboratory equipment and flasks that contacted the sample were sterilized before use with either an autoclave or by soaking in 90 percent ethyl alcohol for $15 \mathrm{~min}$. All samples were refrigerated and stored on ice until analysis within 24 hours of collection. For analysis, the sediment sample was first homogenized by stirring for $1 \mathrm{~min}$. Then, a 10-percent mass/volume slurry was made with the sediment sample by adding $10.0 \mathrm{~g}$ of drained-wet sediment sample (weighed to $\pm 0.01 \mathrm{~g}$ ) to a glass Erlenmeyer flask containing $90.0 \mathrm{~mL}$ of sterile phosphate buffer. The flask was covered with aluminum foil. The flask was shaken briefly for 10 seconds and then immediately placed in an L\&R Transistor/ Ultrasonic T-14 sonication bath for $3.0 \mathrm{~min}$. Large particles were allowed to settle out by waiting $2.0 \mathrm{~min}$ after sonication. After $2.0 \mathrm{~min}$, the tip of the pipette was placed $2 \mathrm{~cm}$ below the surface and $10.0 \mathrm{~mL}$ was immediately transferred into a flask containing $90.0 \mathrm{~mL}$ of buffer. If necessary, additional 1 to 10 dilutions were made.

The membrane filtration method was used to enumerate coliform concentrations. The flask containing the sample to be filtered was shaken vigorously by hand for 10 seconds before each aliquot for enumeration was withdrawn from the flask. The diluted sample was then filtered onto a Whatman, $0.45-\mu \mathrm{m}$ pore size, $47 \mathrm{~mm}$ diameter, white grid, cellulose nitrate membrane filter. However, if the $10^{-2}$ dilution was used, the liquid portion was poured off into another flask after the 2.0 min settling period and filtered. This step removed larger particles that would interfere with colony separation.

To ensure adequate bacteria counts, each sample was plated at two different filtration volumes and four replicates were prepared for each volume. Before filtering a sample, an estimate would be made as to which dilution of the sediment sample would produce between 20 and $80 \mathrm{CFU} / \mathrm{mL}$. Four 5 -mL aliquots of the dilution would be filtered onto individual filters; followed by an additional four 7-mL aliquots of the same dilution yielding eight agar plates per sample. 


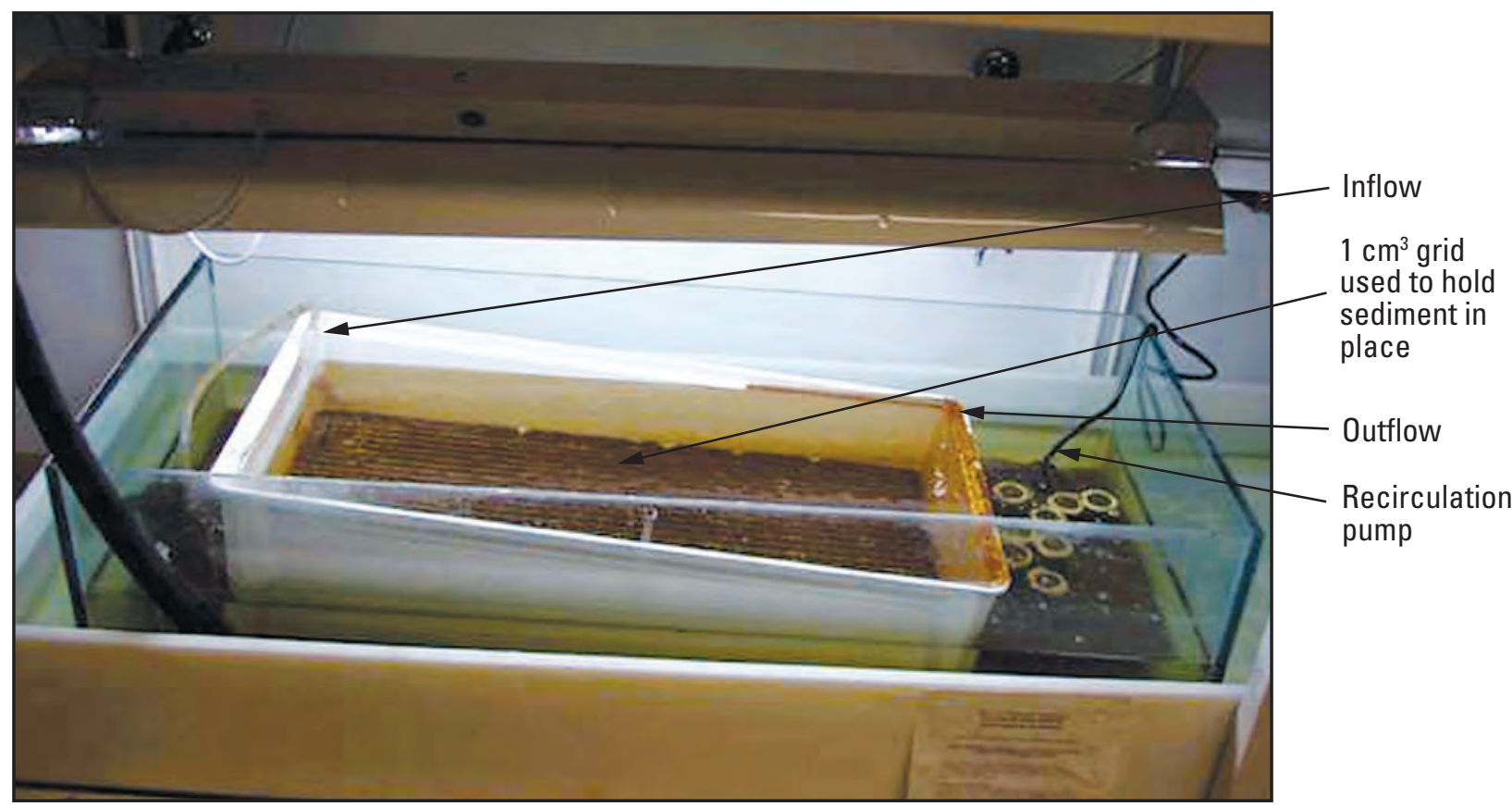

Figure 3. Microcosm chamber used in sediment bacteria attenuation study.

Bed sediment material was retained in place with at $1 \mathrm{~cm}^{3}$ plastic grid and continuous flow was maintained over the $1-2 \mathrm{~cm}$ thick bed sediment with a recirculating pump.

\section{Ground Water/Surface Water Interactions}

Various techniques have previously been used at a number of sites throughout the lower Nooksack River basin to identify locations where ground water discharges directly to streams. Aerial images generated from Forward Looking Infra-Red (FLIR) videography have been used along portions of the mainstem of the Nooksack River as well as portions of the South Fork of the Nooksack River (Watershed Sciences, LLC, 2002). Synoptic low-flow discharge measurements, or seepage runs, have been used along Fishtrap and Bertrand Creeks to identify locations of ground-water discharges and quantify the amount of water either gained or lost by the streams (R.A. Kimbrough, U.S. Geological Survey, written commun., 2002). These studies were used in the selection process to select sites where more detailed information on ground water/surface water interactions would be collected.

\section{Longitudinal Profile of South Fork Nooksack River}

To identify specific locations of discharging ground water, a longitudinal survey of surface-water temperatures near the riverbed was conducted on the 14-mile reach of the South Fork Nooksack River between the Skookum Creek Fish Hatchery and the confluence with the North Fork of the Nooksack River (fig. 1). River-water temperatures typically show a diurnal pattern of steadily increasing temperatures during the day as solar energy is adsorbed followed by nightly cooling. In the longitudinal survey, stream reaches where the rate of water temperature increase is substantially smaller than the average or where decreasing temperature trends are measured are interpolated as springs or seeps where cooler ground-water discharge is occurring.

The longitudinal thermal profile survey was conducted between 9:00 a.m. and 4:00 p.m. on August 28, 2003, during the rising limb of the river's diurnal temperature cycle. The recorded water temperature near the streambed ranged from 
about $14^{\circ} \mathrm{C}$ at the upstream location near Skookum Creek to $20.6^{\circ} \mathrm{C}$ at the confluence near Deming (fig. 1). Localized temperature variations could be seen in some of the larger deep pools where the river bottom was more insulated from solar radiation, in very shallow areas where solar radiation was sufficient to warm slow moving water, and in areas where riparian cover provided shade during the hottest times of the day. However, these localized variations generally were small due to the amount of mixing caused by turbulence in a flowing river environment and did not adversely affect the water temperature survey.

The longitudinal thermal profile clearly shows five reaches (A, B, C, D, and E) (fig. 4) where river temperatures depart from the diurnal warming trend suggesting the input of cooler ground water. Four of these reaches were adjacent to sedimentary geological deposits that are characteristically permeable and may be locally significant aquifers (fig. 5). Permeable glacial outwash is adjacent to reach $\mathrm{E}$, where water temperatures decreased substantially throughout the reach. Permeable alluvial-fan deposits were adjacent to reach
$\mathrm{D}$ where water temperatures remained cool over a relatively long distance and to reach $\mathrm{C}$ where a distinct cooling trend was observed. Reach B is immediately adjacent to a deposit of recent valley alluvium and reach $\mathrm{A}$ is adjacent to a large landslide deposit.

Although recent valley alluvium typically is composed of fine-grained sediments that are poorly transmissive and do not allow water to flow easily through them, these deposits are often of limited thickness. In this setting, permeable glacial outwash, that is highly transmissive, is adjacent to the alluvium on both sides of the river and likely occurs beneath the alluvium. The cooler stream water temperatures in reaches $\mathrm{B}$ and A likely are due to ground water discharging to the river from this glacial outwash deposit at the downstream end of the South Fork valley.

Ground water was discharging unevenly along the South Fork Nooksack River. Interpreted ground-water discharge areas appear to be adjacent to geologic deposits that may contain sufficient coarse-grained materials for aquifer formation. No sites along the South Fork Nooksack River were selected for detailed study of discharging ground water or further monitoring.

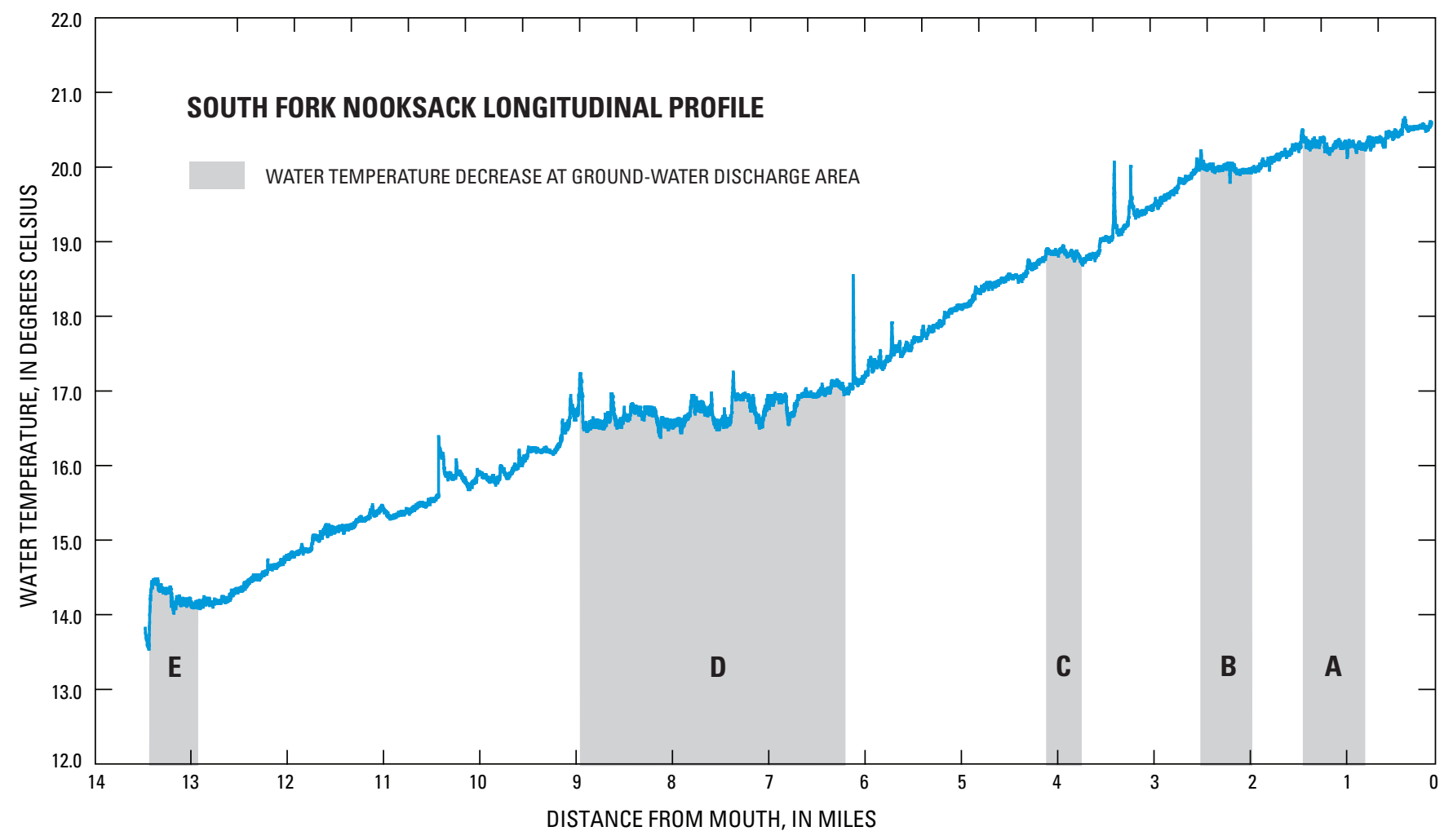

Figure 4. Thermal profile of the South Fork Nooksack River, Whatcom County, Washington, August 28, 2003. 


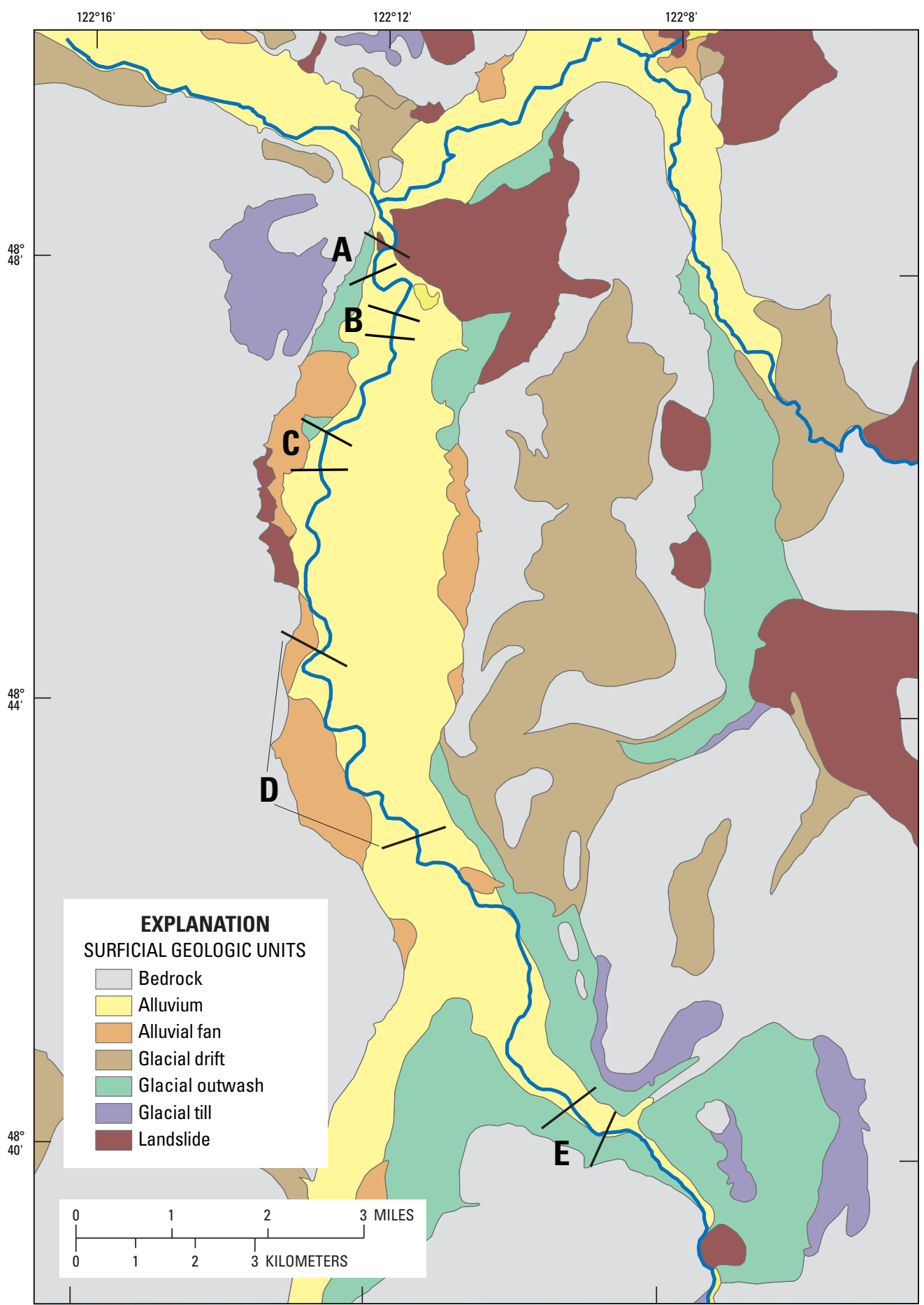

Base from U.S. Geological Survey, 1954

Bellingham Quadrangle, Revised 1994; scale 1:24 000

Digital Geology-Geology of the quadrangle was compiled by staff geologist T.J. Lapen.

J.E. Shuster digitized and attributed the geologic data.

Washington State Department of Natural Resources, Division of Geology and Earth Resources, 1:100,000-Scale Digital Geology of Washington State. Projection: Washington Stateplane South; Zone 5626, Datum NAD27

Figure 5. Generalized surficial geology and location of reaches of discharging ground water, South Fork Nooksack River, Whatcom County, Washington. 


\section{Ground-Water Discharge Study Sites}

\section{Nooksack River near Everson}

The FLIR images taken along the mainstem of the Nooksack River showed a number of locations along portions of the riverbank where cooler surface temperatures might indicate the locations of ground-water discharge (Watershed Sciences, LLC, 2002). At a site about 2 mi upstream of the town of Everson, the FLIR image showed cooler surface temperatures along the right bank of the Nooksack River (fig. 6). At this location, the river channel is divided into two channels separated by a gravel island partly covered with brushy vegetation estimated to be less than 5 years in age. The main flow of the river follows the west or left bank channel and a subordinate channel flows along the right bank of the river adjacent to agricultural pasture lands. Further reconnaissance of the site revealed ground-water seepage from the bluff beneath the adjacent pasture land.

At one location, ground-water seepage with estimated flow of 100 to $200 \mathrm{~mL} / \mathrm{min}$ was observed flowing over the land surface and into the river (fig. 6 inset). Vertical hydraulic gradients between surface water and the underlying ground water were measured using a manometer board at 10 sites along the subordinate channel and at 4 sites on the west side of the island along the main river channel.

Specific conductance was used to help distinguish between ground water and surface water. Specific conductance was $88 \mu \mathrm{S} / \mathrm{cm}$ in water samples from the river and ranged from 241 to about $500 \mu \mathrm{S} / \mathrm{cm}$ in ground water from wells in the area adjacent to the riverbank (table 1, at back of report). Along the right bank channel and shoreline, the vertical hydraulic gradient was positive (or upward) ranging from 0.08 to 0.25 $\mathrm{ft} / \mathrm{ft}$ during the manometer board survey. Specific conductance in ground water ranged from 207 to $247 \mu \mathrm{S} / \mathrm{cm}$ during the manometer board survey.

The largest vertical hydraulic gradient $(0.25 \mathrm{ft} / \mathrm{ft})$ was measured near the area where 100 to $200 \mathrm{~mL} / \mathrm{min}$ groundwater seepage was observed flowing into the Nooksack River. The variation of vertical hydraulic gradients was more than an order of magnitude although the variation in specific conductance was much more limited. The larger variation in vertical hydraulic gradient compared to specific conductance is likely due to local variations in permeability of aquifer materials. The cooler temperatures observed in the FLIR image, the upward vertical hydraulic gradients observed in the manometer survey, and the limited variation in specific conductance of shallow ground water all indicate groundwater discharge (fig. 6) at this site.
On the west side of the gravel island along the right bank of the main channel, vertical hydraulic gradients in shallow ground water were negative (or downward). In addition, the specific conductance of water pumped from the piezometers ranged from 96 to $99 \mu \mathrm{S} / \mathrm{cm}$, which was very similar to the specific conductance of surface water ( 88 to $89 \mu \mathrm{S} / \mathrm{cm}$ ) indicating that river water was flowing downward into the streambed. The downward vertical gradients may represent flow within the rivers hyporheic system as a minor riffle was present about $300 \mathrm{ft}$ downstream.

To evaluate temporal variations in ground-water discharge at this site, hourly measurements of surface-water levels of the Nooksack River and ground-water levels beneath the riverbed were recorded from November 2002 to October 2004 (fig. 7). A temporary surface-water gaging station was established on the east bank of the east channel near the center of the ground-water discharge area (fig. 6). The gaging station consisted of a water-level data logger installed in a pipe open to the Nooksack River although another data logger was installed in a nearby piezometer driven $6.5 \mathrm{ft}$ below the streambed. Data from both data loggers are referenced to a common arbitrary reference datum so that water levels could be directly compared.

Surface-water levels measured in the Nooksack River ranged from 15.4 to $27.8 \mathrm{ft}$ above the reference datum whereas ground-water levels beneath the riverbed ranged from 16.8 to $22.9 \mathrm{ft}$ above the reference datum. The surface-water and ground-water hydrographs (fig. 7A) reveal very similar patterns in the rise and fall of water levels throughout most of the year although the range of variation for surface water was nearly twice as large as that of ground-water levels. Groundwater levels typically were 0.98 to $1.31 \mathrm{ft}$ higher than surfacewater levels indicating an upward vertical hydraulic gradient ranging from 0.17 to $0.22 \mathrm{ft} / \mathrm{ft}$. However, during periods of very high river stage, surface-water levels often exceeded ground-water levels. During these brief periods of very high river stage, the vertical hydraulic gradient was downward, reaching values as low as $-0.8 \mathrm{ft} / \mathrm{ft}$ as river water flowed through the streambed and into the underlying ground-water system or moved into bank storage. The downward vertical hydraulic gradients that occurred during high discharge events, were of short duration, lasting only a few hours. Positive (or upward) vertical gradients returned immediately or within a few hours after the flood crest had passed and surface-water levels declined below a stage of about $22 \mathrm{ft}$ (fig. 7A). During the 16,800 hours of recorded data, a positive vertical hydraulic gradient, indicating discharging ground water, was recorded 98 percent of the time; the exceptions being brief periods of extreme high river flows. 


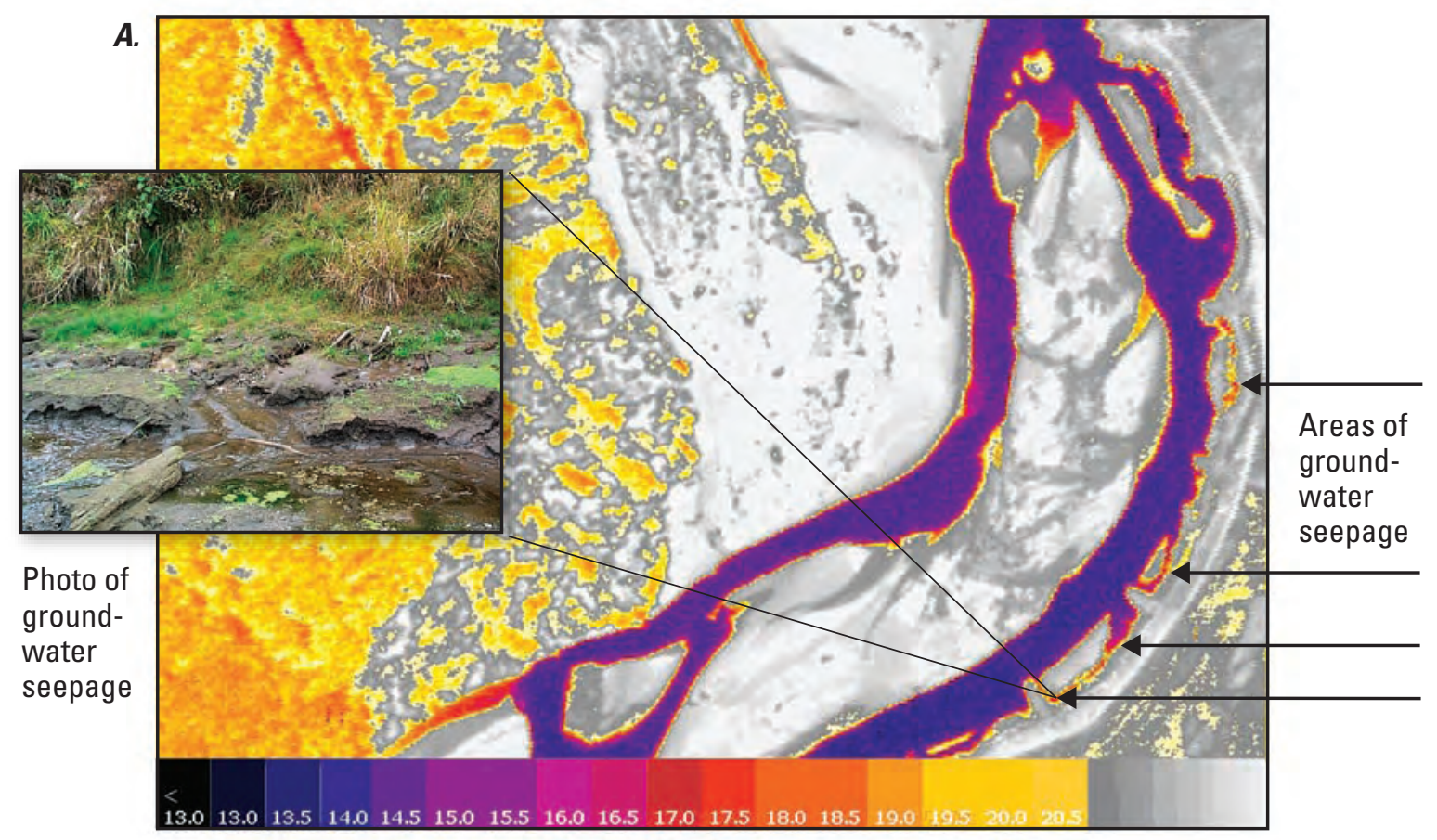

B.

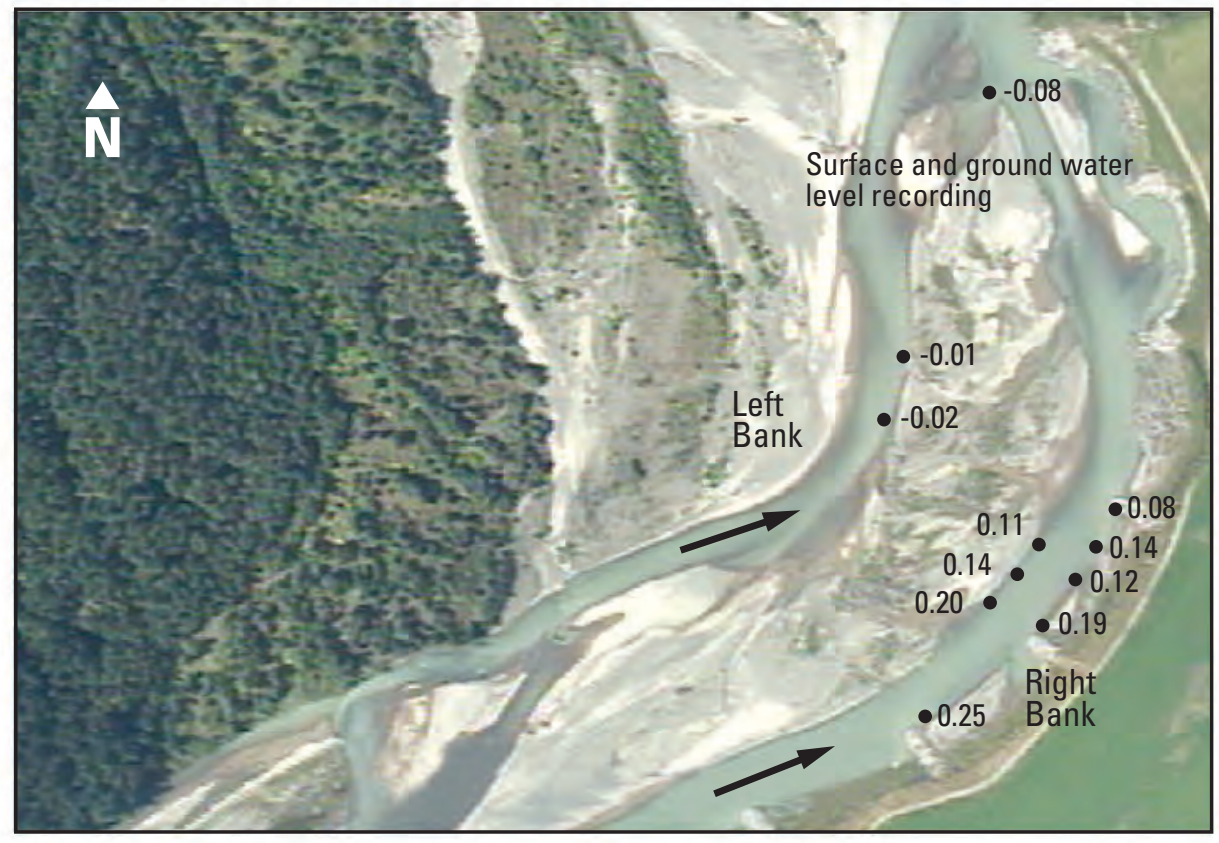

Figure 6. Oblique view and thermal image from Forward Looking Infrared Radar (FLIR) of the detailed ground-water study site at the Nooksack River 2 miles south of Everson, lower Nooksack River basin, Whatcom County, Washington. 

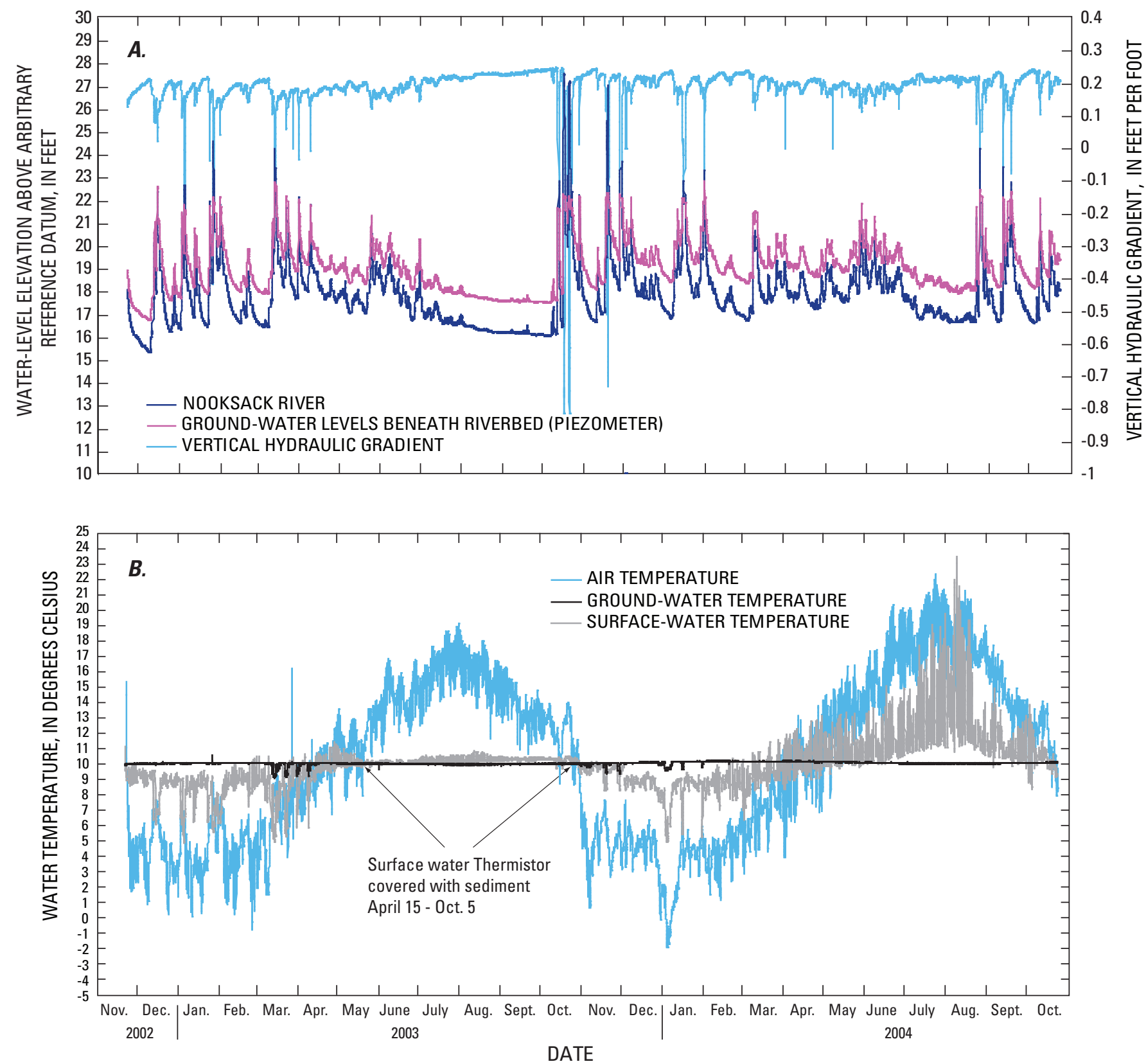

Figure 7. Continuous water-level and vertical hydraulic gradient data and temperatures of surface water and ground water at the Nooksack River near Everson, Whatcom County, Washington, 2002-04.

Hydrostatic pressure effects resulting from river stage is the likely reason ground-water levels mimic surfacewater levels, rising and declining roughly to the same extent while maintaining a head difference of 1.0 to $1.3 \mathrm{ft}$ (fig. 7A). However, there appears to be an upper limit on the ability of ground-water levels to respond to river stage. At this site, that limit corresponds to a ground-water level between 21.3 and $21.7 \mathrm{ft}$. The extent that downward vertical hydraulic gradients are able to develop depends on how much higher surface-water levels rise above the 21.3 to $21.7 \mathrm{ft}$ range.
Comparison of surface-water and ground-water temperatures confirms that ground-water discharge occurs throughout the year at the Nooksack River site (fig. 7B $)$. Over the annual cycle, the temperature of ground water beneath the streambed of the Nooksack River remains constant to within a few degrees of the base-line temperature of about $10^{\circ} \mathrm{C}$. Surface-water temperatures typically displayed daily and seasonal variations ranging from 3 to $10^{\circ} \mathrm{C}$ becoming larger during the summer months. If surface water is moving into the ground-water system through the streambed, then the 


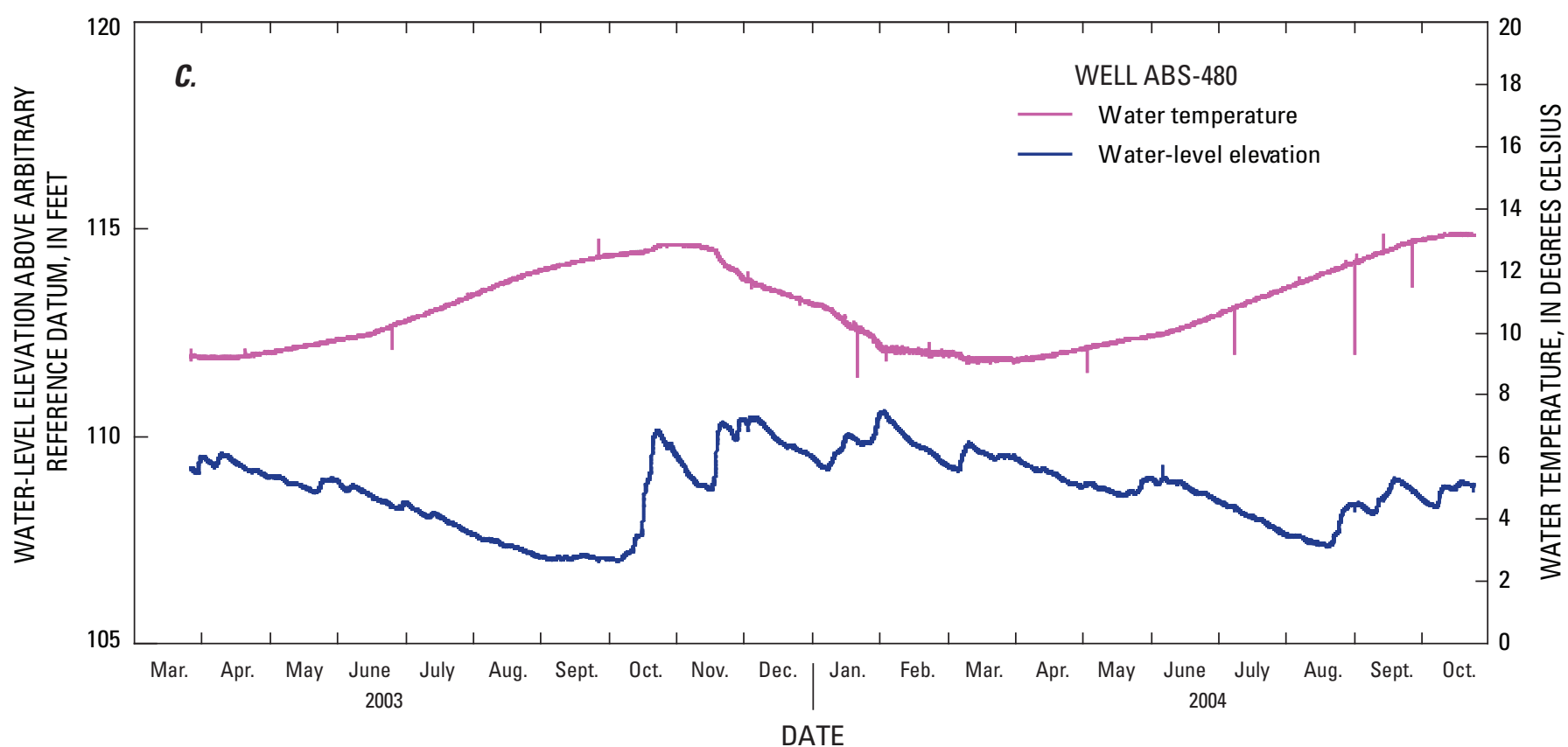

Figure 7. Continued.

temperature signal of shallow ground water beneath the river may show a similar seasonal and diurnal pattern of variation. The recorded ground-water temperatures at the Nooksack River site did not vary substantially from $10^{\circ} \mathrm{C}$ indicating that there was only very limited movement of surface water into ground water underlying the riverbed (fig. $7 B$ ). Shortduration perturbations of ground-water temperatures were measured during flood peaks when water levels in the river were sufficiently high to develop a negative vertical hydraulic gradient, thus allowing cold surface water to move into the underlying ground-water (fig. 7B).

Comparison of surface-water levels in the Nooksack River to ground-water levels beneath the riverbed and the adjacent uplands indicate that both respond similarly to changing hydrologic conditions at the site. Precipitation/runoff events within the drainage basin commonly generate sharp peaks on the surface-water hydrograph followed by more gradual water-level declines (fig. 7A). Similar patterns were observed in the ground-water hydrograph except that the peak ground-water elevations do not occur simultaneously. Peak ground-water levels typically occurred within a few hours of the peaks in the surface-water hydrograph, although in some cases, the peaks were as much as 14 hours apart, and on a few occasions apparently preceded peak surface-water elevations.
Ground-water levels in the aquifer beneath the adjacent field represented by the hydrograph for well ABS-480 (fig. 7C) show some similarity to water levels that were measured in the in-stream piezometer beneath the Nooksack River near Everson as lowest water levels recorded in both ground water sites occurred in the late summer to early autumn time frame. However, the range of water-level variation measured in well ABS-480 was about one-half of that measured in the in-stream piezometer beneath the Nooksack River near Everson and did not exhibit the surfacewater response pattern measured in that piezometer (fig. 7A). Marked differences were observed in the ground-water temperature data from the two sites. Annual water temperature cycle of about $4^{\circ} \mathrm{C}$ was measured in well ABS-480 but not observed in the piezometer installed beneath the streambed of the Nooksack River where measured temperature variations were limited to about $1.1^{\circ} \mathrm{C}$. The limited temperature variation measured in the in-stream piezometer beneath the Nooksack River near Everson is consistent with discharging ground water from deeper portions of the aquifer where water temperatures remain more constant than near the water table as in well ABS-480. 


\section{Fishtrap Creek}

Fishtrap Creek was included in this study because it is a primary stream draining an area of intense agricultural and urban land use, and because contamination by fecal coliform bacteria has been documented as a water-quality issue in this stream (Joy, 2000). In addition to discharging ground water, the creek is fed by tile drains and ditches that drain agricultural fields. Barnyard manure is sprayed seasonally on many of these fields to amend soil nutrients.

Reconnaissance investigations used a network of nine instream piezometers installed from the Canadian border to near the confluence with the Nooksack River (fig. 8). Continuous data were collected near one of the stations in the network (PZF-3) where data loggers were installed to collect hourly water-level and water-temperature data for surface water and ground water beneath the streambed. In addition, two transects of three piezometers each were installed perpendicular to the creek at the ground-water discharge study site near PZF-2.

\section{In-Stream Longitudinal Piezometer Network}

Vertical hydraulic gradients were measured along the network of in-stream piezometers every few months from September 2002 to June 2004. At most of the monitoring sites, the vertical hydraulic gradients varied seasonally and generally were upward indicating discharging ground water. The magnitude of the vertical hydraulic gradients typically were larger during the winter precipitation period from November to April and smaller from June to September during the summer and late autumn (fig. 9). The direction of water flow changed seasonally in some piezometers (PZF-1, PZF-2). Vertical hydraulic gradients were positive during the wet winter months indicating upward flow of discharging ground water; however, vertical hydraulic gradients were negative during the late summer period indicating downward flow of surface water recharging the ground-water system. Seasonal variations in vertical hydraulic gradients were most pronounced in the upstream agricultural areas near the Canadian border (piezometers PZF-1, PZF-2, and PZF-3) and smallest in the

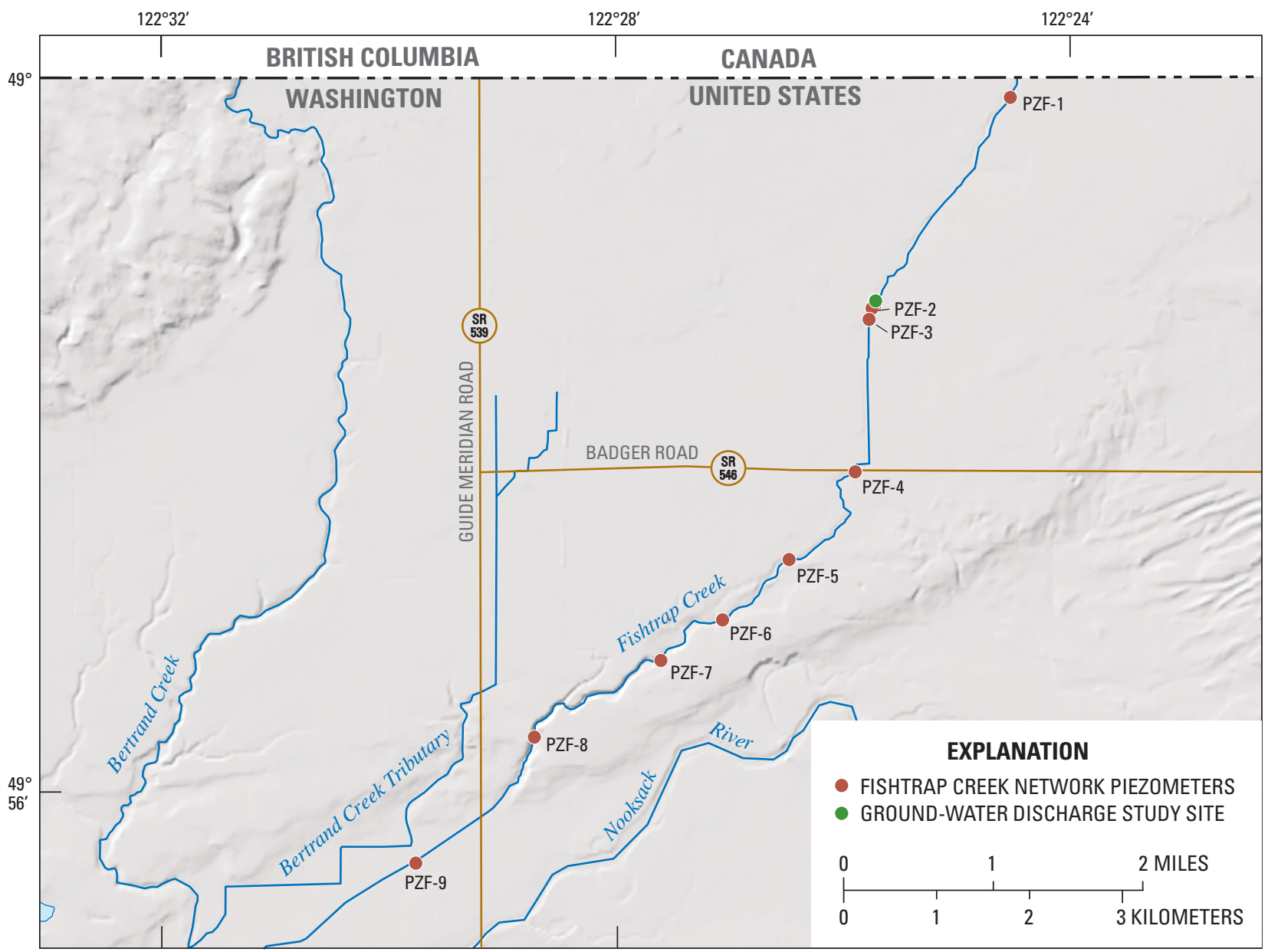

Figure 8. Location of vertical hydraulic gradient monitoring network, and ground-water discharge study site on Fishtrap Creek, lower Nooksack River basin, Whatcom County, Washington. 


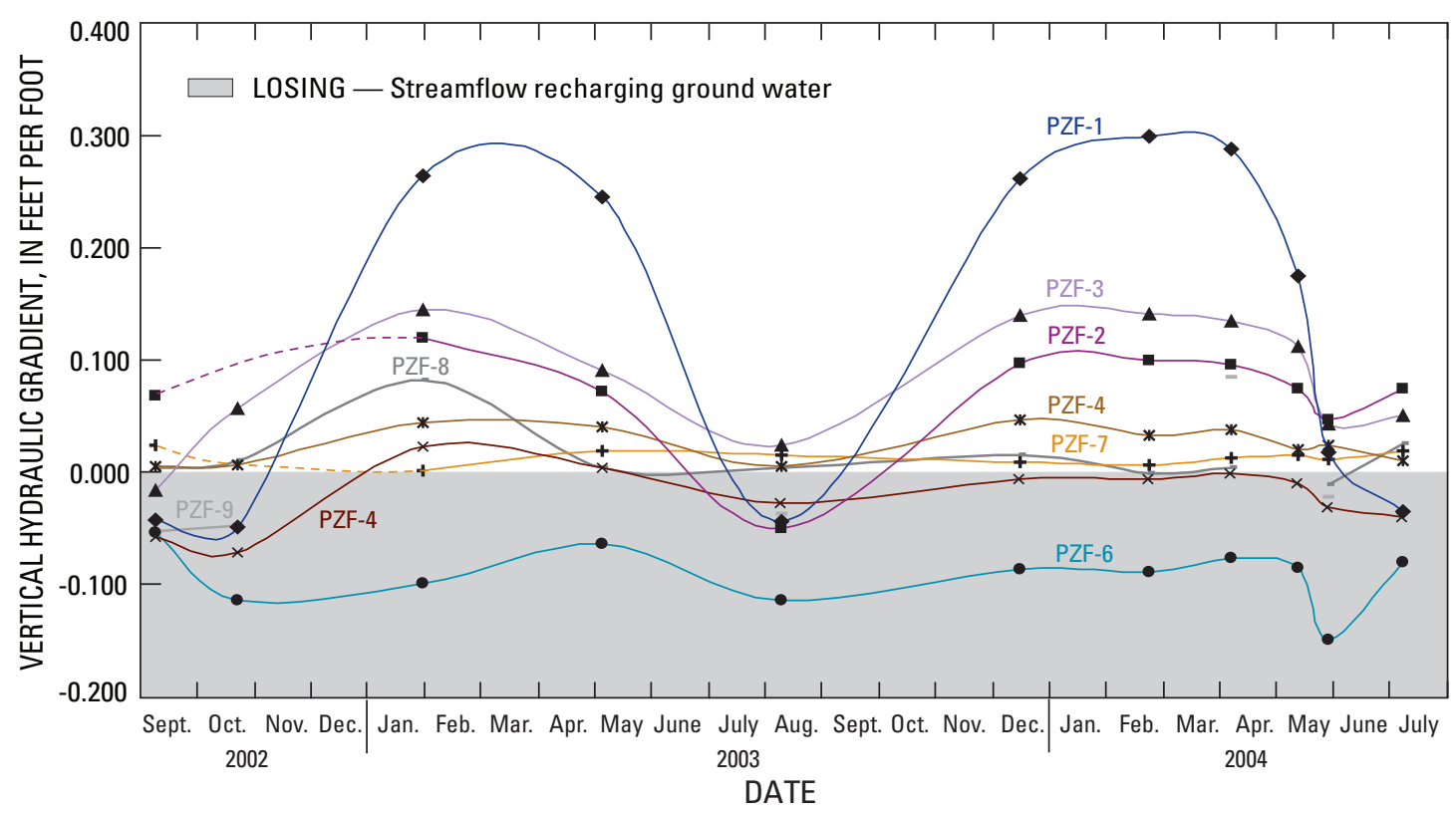

Figure 9. Seasonal variations in vertical hydraulic gradients in ground water beneath the streambed of Fishtrap Creek, from the Canadian border to the confluence with the Nooksack River, Whatcom County, Washington, September 2002-July 2004

Locations of piezometers are shown in figure 8.

downstream reaches from the town of Lynden to the mouth of the creek (piezometer PZF-9) (fig. 9). Vertical hydraulic gradients generally were upward during the study period at all piezometers except for PZF-6, where the vertical hydraulic gradient was consistently downward. Downward vertical gradients at this location may be related to the surrounding geography as this piezometer is near the break in slope where the Fishtrap Creek channel has eroded into the alluvial terrace of the Nooksack River and may not have incised to the level of the regional ground water table.

Vertical hydraulic gradients also were measured periodically in two perpendicular transects of piezometers installed near PZF-2 (fig. 10). Manometer board measurements taken intermittently from October 1, 2003, to May 6, 2004 indicate that vertical hydraulic gradients are more positive during February and March 2004 (fig. 10) consistent with the seasonal pattern exhibited in PZF-2, which was 30 $\mathrm{ft}$ downstream. The pattern of vertical hydraulic gradients near the stream channel suggests that ground-water flow is not symmetrical to the streambed at this location although the topography near this site generally is flat. Vertical hydraulic gradients were consistently lower at the center of the channel than either bank and gradients on the left bank generally were more positive than the right bank. These patterns suggest the potential for larger ground-water fluxes from the field southeast of the piezometer nest than fluxes from the northwest field, thus providing further evidence that source areas contributing ground-water discharge to streams can be variable at the field scale. Although most of the measured vertical hydraulic gradients were positive, indicating upward ground-water flow, brief periods of high streamflow appear to have induced downward flow in October 2003 at the downstream transect and in November 2003 at the upstream transect.

Hourly measurements of surface-water levels in Fishtrap Creek and ground-water levels in a piezometer installed to a depth of $5 \mathrm{ft}$ beneath the streambed were recorded from April 2003 to August 2004 in order to evaluate temporal variations in ground-water discharge. When referenced to a common arbitrary datum, these data show that ground-water levels generally were higher than the water level in streams (fig. 11). Exceptions were noted during short-duration stream discharge events such as a storm on July 12 and 13, 2003, in which 2.2 in. of precipitation was recorded at a weather station $4 \mathrm{mi}$ north of Fishtrap Creek. During this storm, the increase in hydraulic head monitored in the ground water began on July 12 at 9 p.m. while increased stage in Fishtrap Creek was not seen until 2 hours later at 11:00 p.m. However, the water level in Fishtrap Creek did eventually exceed the hydraulic head of the ground water resulting in a negative vertical hydraulic gradient for about 18 hours. Analysis of individual storm events indicates that surface-water and ground-water levels respond rapidly to precipitation events, and periods of negative vertical hydraulic gradients occur during peak streamflows, but typically are of short duration. 


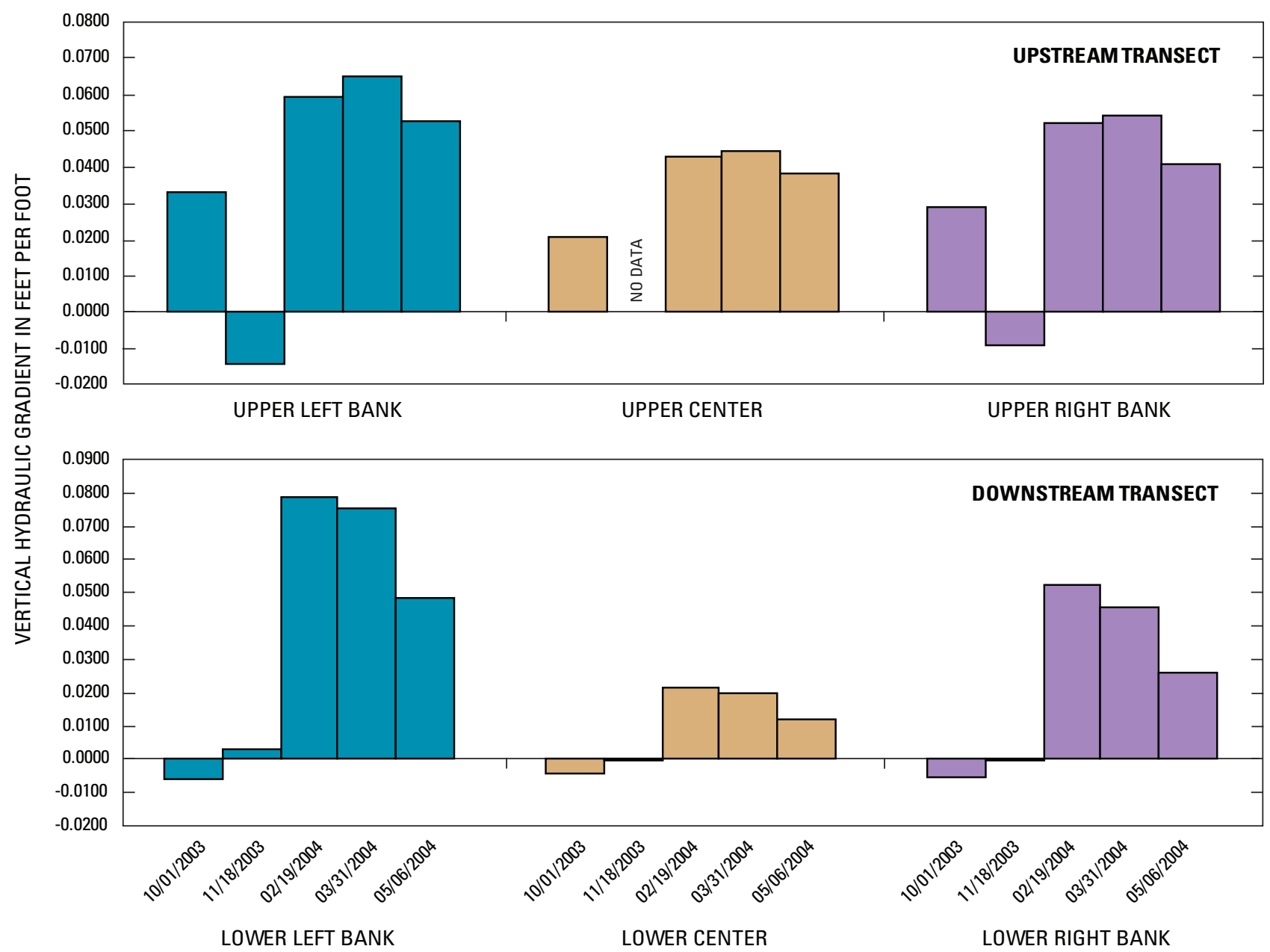

Figure 10. Seasonal variations in vertical hydraulic gradients in ground water beneath the streambed measured at two piezometer transects across Fishtrap Creek, lower Nooksack River basin, Whatcom County, Washington, October 2003 to May 2004.

Vertical hydraulic gradients became less positive from early July to early September 2003, and during the same period in 2004, the vertical hydraulic gradient became negative from July 7 to September 12 (fig. 11). The water temperature record for this site confirms the downward flux of warm surface water during late summer 2004. The temperature record shows that surface water undergoes both diurnal and seasonal variations and ground water generally remains at a consistent $10^{\circ} \mathrm{C}$ throughout the year. However, during the late summer dry period of 2004, downward flow through the streambed caused a substantial increase in ground-water temperature at this site (fig. 11). Ground-water temperatures gradually returned to an ambient $10^{\circ} \mathrm{C}$ after the vertical hydraulic gradient returned to a positive value indicating upward flow in early September 2004.
The negative vertical hydraulic gradient measured during the late summer of 2004 may be related to changing hydraulic conditions within the stream or the adjacent riparian corridor. The growth of vegetation within and adjacent to the creek channel increases substantially during the later one-half of the summer impeding streamflow and resulting in higher water levels within the stream channel. Irrigation return flows from tile drains also may help to sustain stream stages as groundwater levels continue to decline during the dry season. Either of these factors could combine to cause negative vertical hydraulic gradients during late summer.

The effects of an artificial increase in stream stage were observed during a site visit to piezometer PZF-2 in August 2004. Woody debris had accumulated on a small constriction just downstream of a network piezometer, possibly placed 

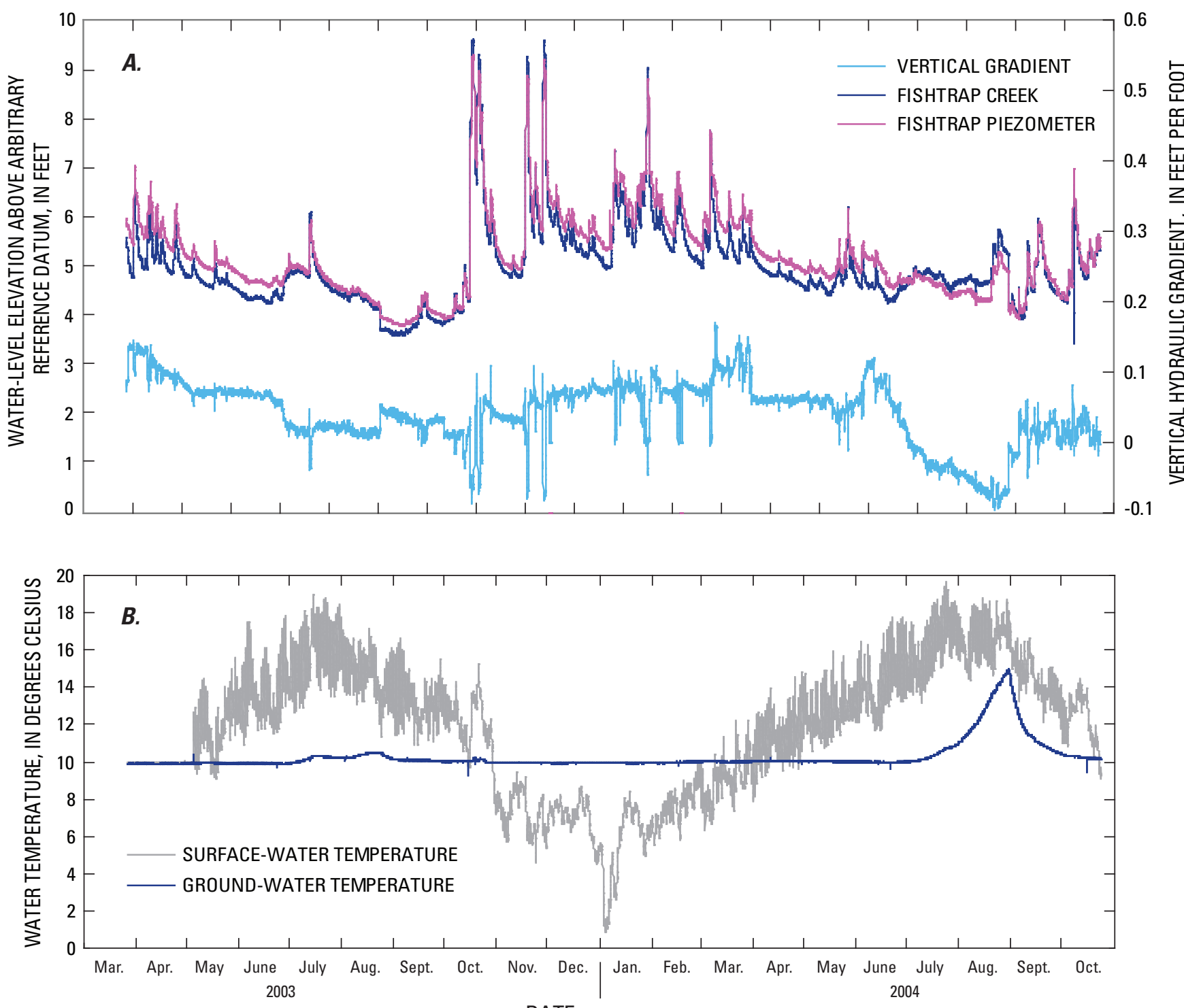

Figure 11. Continuous water level and vertical hydraulic gradient data and temperatures of surface water and ground water at Fishtrap Creek at Pangborn Road, lower Nooksack River basin, Whatcom County, Washington, March 2003 to October 2004.

there by beaver or other animals. The manometer board measurement made before removal of the debris indicated a negative (downward) vertical hydraulic gradient. Following the removal of the debris, the pool elevation in the creek declined 4.3 in. then stabilized. Repeat measurements of the vertical hydraulic gradient indicated a positive value as did a follow-up measurement the next day. This condition may explain some of the variation in the measurements of vertical hydraulic gradient shown in the piezometer transect near PZF-2 in figure 10. Thus, local site conditions can be important when interpreting hydraulic gradient data. 


\section{Fourmile Creek}

Fourmile Creek was selected as a ground-water discharge study site because it is a low order stream draining an area of intense agricultural production. Fourmile Creek originates from Green Lake and surrounding wetlands (fig. 1) where it flows generally west to join Tenmile Creek just west of the Guide Meridian, which in turn flows into the Nooksack River near Ferndale. Like Fishtrap Creek to the north, the groundwater discharge study site is in an agricultural area subject to manure applications and where tile drains have been used to artificially drain fields. Initial installation of monitoring equipment was disrupted by dredging of the stream channel during autumn 2003. About $3 \mathrm{ft}$ of organic sediments were removed from the channel exposing fine to medium sand in the streambed. The water table in the area was measured at depths of about 2 to $5 \mathrm{ft}$ below the land surface, close enough to the surface to require tile drains for artificial drainage to lower the water-level elevation in order to prepare for planting crops in the spring.

Two transects of three piezometers each were installed perpendicular to the creek at the ground-water discharge study site on Fourmile Creek. Vertical hydraulic gradients were measured in each piezometer with a manometer board four times from February through May 2004 (fig. 12). Vertical hydraulic gradients were consistently positive; however, at most sites, the positive gradient tended to become smaller from February through early May 2004. Precipitation in late May 2004 could have caused the anomalously positive values in the right bank and center of the upper transect and slightly more positive values in the center and left bank of the downstream transect (fig. 12). Vertical hydraulic gradients were consistently more positive on the right bank and progressively less positive toward the left bank suggesting that ground-water fluxes probably are higher on the northwest side of the creek at this site. Data from this site show both the spatial and temporal variability in surface water/groundwater interactions at a field scale. Such variations are likely due to heterogeneities within aquifer materials underlying the streambed, local topography, the placement of tile drains, or other factors. Precipitation also may influence localized ground-water discharge.

A temporary gaging station was established at the Fourmile Creek site and continuous water-level data were collected from December 2003 to October 2004 (fig. 13). Ground-water levels recorded in a piezometer installed to a depth of $5.4 \mathrm{ft}$ below the streambed were consistently higher than surface-water levels throughout the study period indicating that gaining conditions predominate throughout the year.

Vertical hydraulic gradients were upward and generally were larger during winter and autumn than during the summer months. Ground-water temperatures were relatively constant throughout the study period, with a difference of $4.2^{\circ} \mathrm{C}$ between the coolest temperature in January and the warmest temperature in September (fig. 13). Surface-water temperatures at the Fourmile Creek site did not show as strong a diurnal signal as observed at other sites. Stream temperatures at this site may have been buffered by ground water discharging at a nearly constant temperature or influenced by riparian vegetation that create shaded conditions that were more common along Fourmile Creek than at other sites. The nearly identical response in ground-water levels and surface-water stage at this site may be due to the fact that the streambed is composed of well-sorted, un-compacted sand with a loose quicksand-like texture. The loose-open texture allowed unimpeded hydraulic connection between ground water and surface water resulting in little if any lag effect as precipitation and runoff events varied the flow in Fourmile Creek. The effect of dredging the stream channel appears to have enhanced the communication between surface water and the underlying aquifer and, in this case, increased the rate of ground-water discharge. 


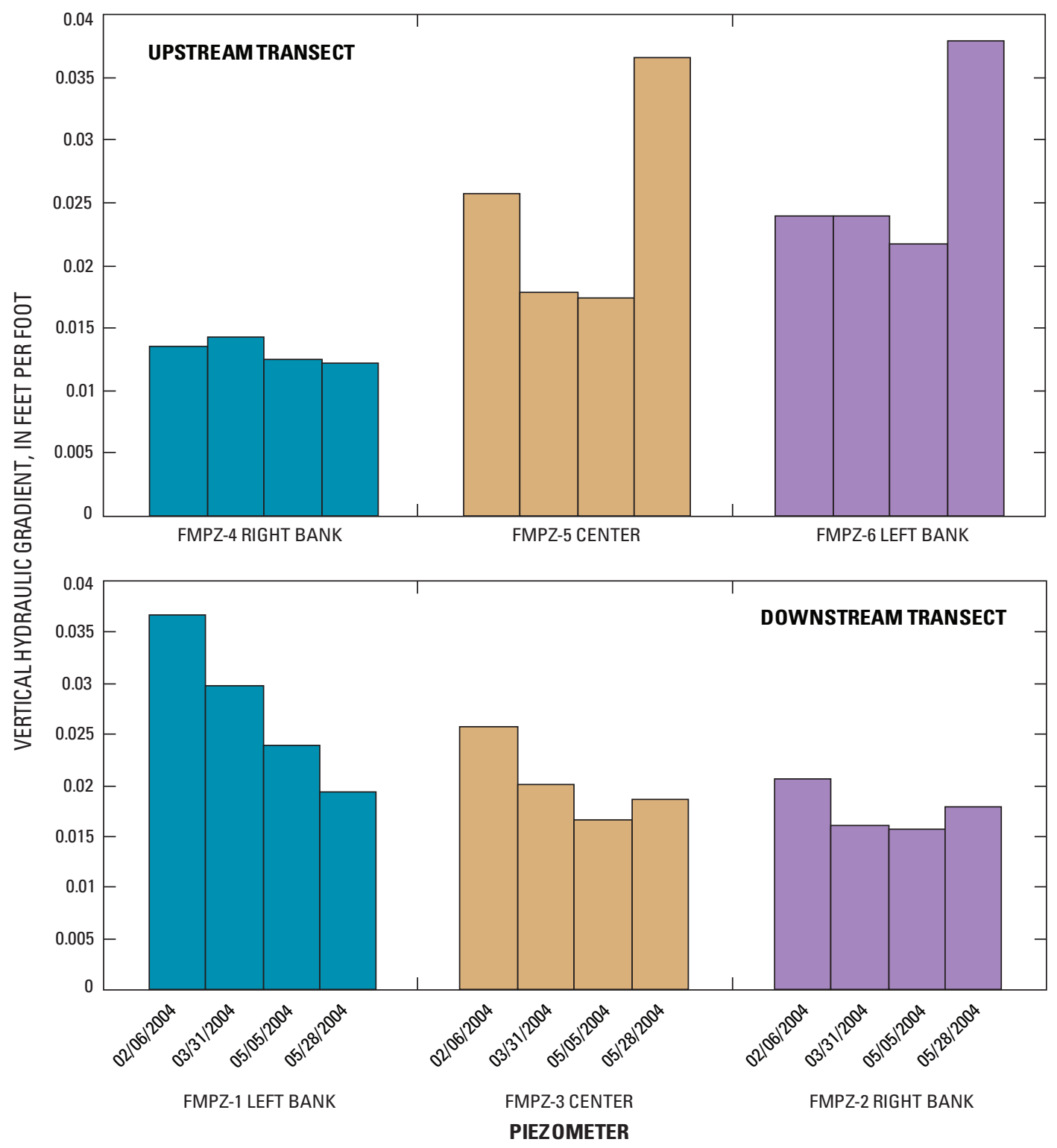

Figure 12. Seasonal variations in vertical hydraulic gradients in ground water beneath the streambed measured at two piezometer transects across Fourmile Creek, lower Nooksack River basin, Whatcom County, Washington, February to May 2004. 


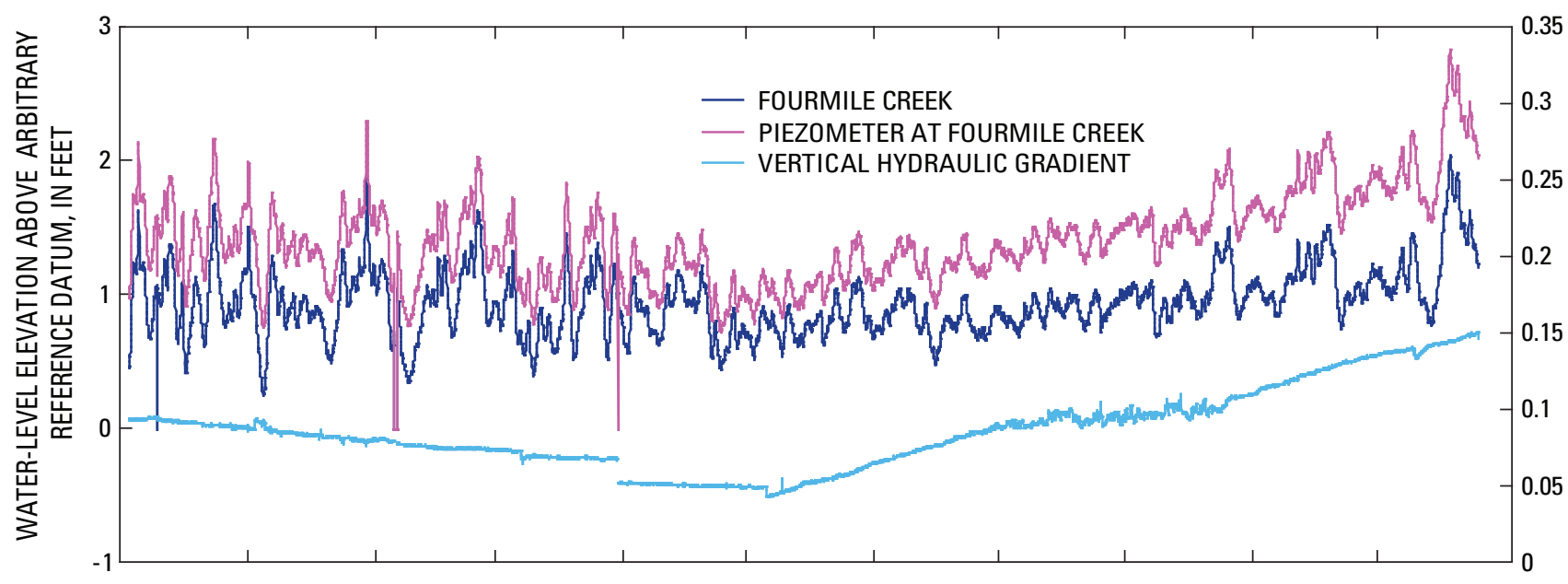

充

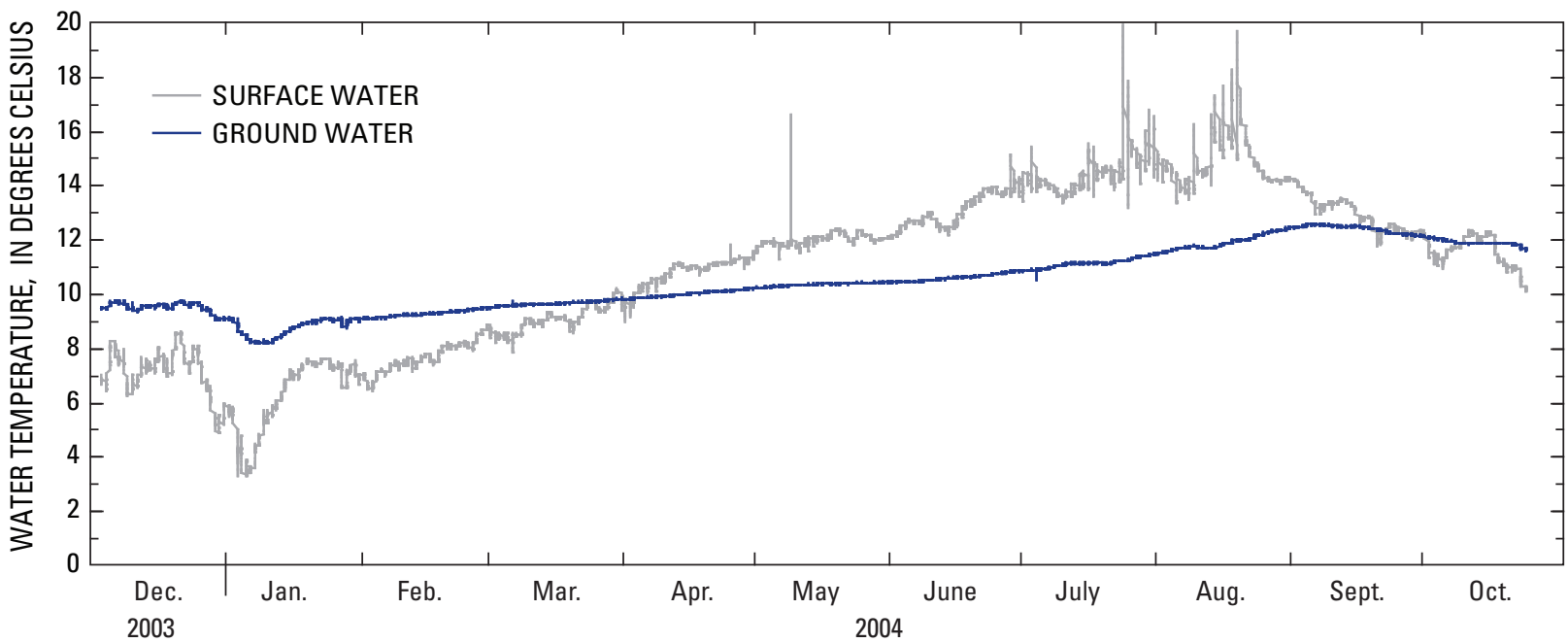

DATE

Figure 13. Continuous water level and vertical hydraulic gradient data and temperatures of surface water and ground water at Fourmile Creek near Guide Meridian, lower Nooksack River basin, Whatcom County, Washington, December 2003 to October 2004. 


\section{Bertrand Creek}

The Bertrand Creek ground-water discharge study site was selected to assess the impacts of agricultural practices on water quality at a field scale. The study site is actually located on a small drainage ditch that is tributary to Bertrand Creek. The ditch originates from and flows through fields in agricultural production, northwest of Lynden, Washington (fig. 1). The tributary flows through a manmade ditch that drains fields used primarily for hay and grass dairy feed. Manure was applied to fields using traditional spray methods on the east side of the ground-water discharge study site, and a newer injection method was used on the west side.

A temporary gaging station was installed adjacent to an in-stream piezometer in March 2003 and routine sampling and vertical hydraulic head was measured in September 2003. Continuous data loggers were installed in the tributary in December 2003 but the channel was dredged on February 14,2004 , and several months of continuous data were lost. The dredging removed accumulated mud and sediments in the channel and exposed sandy material on the streambed. In March 2004, the temporary gaging station was re-established and a new ground-water piezometer was installed to a depth of $6.5 \mathrm{ft}$ beneath the streambed. Continuous data loggers were installed to collect hourly ground-water and surface-water levels, as well as, water-temperature data.

Three transects of three piezometers each were installed perpendicular to the drainage ditch at intervals of about $50 \mathrm{ft}$. The surface-water gaging station was installed at the center transect. Vertical hydraulic gradients were measured throughout the autumn and winter of 2003 and into the spring and summer of 2004 in each of the nine piezometers (fig. 14).

Vertical hydraulic gradients were most positive in February when winter precipitation was greatest. Gradients gradually became less positive through the spring and early summer and are assumed to continue to decrease until winter precipitation begins, typically after November. Although downward vertical hydraulic gradients were not measured during the period of study, downward flow could have occurred during the dry summer months. Vertical hydraulic gradients measured in the three piezometers that comprise a single transect generally were consistent. However, downward gradients in the north transect tended to be larger than at the central and south transects suggesting a small component of regional ground-water flow from north to south at the study site. The consistency of hydraulic gradient values across each transect suggests that aquifer conditions at this site possibly are more homogeneous than the other ground-water discharge study sites evaluated as part of this study. Thus, although ground-water discharge varies temporally at this site it does not appear to have a large spatial variation.

Continuous water-level and water-temperature data were collected at Bertrand Creek tributary site from March 30 to October 24, 2004 (fig. 15). Corrections had to be applied to the data to account for drift of the data logger instruments, so the accuracy of the stage data at this site is considered fair. A comparison of stream-stage and ground-water level data indicates that vertical hydraulic gradients were upward from April 2004 to late June 2004, at which time the gradient reversed and became downward. The reversal from upward to downward flow appears to have occurred around June 22, 2004, as indicated by a significant change in both stream and ground-water temperatures (fig. 15). Slow moving and very shallow surface water, no longer buffered by cooler groundwater discharge, was more strongly affected by atmospheric temperature variations. In addition, the warmer, downward moving surface water is indicated in the temperature data from the ground-water sensor at a depth of $6.5 \mathrm{ft}$ below the streambed. Although downward vertical hydraulic gradients were recorded through October 2004, once winter rains begin to recharge the shallow aquifer, the hydraulic gradients were assumed to reverse once again to upward flow through the winter and following spring. 

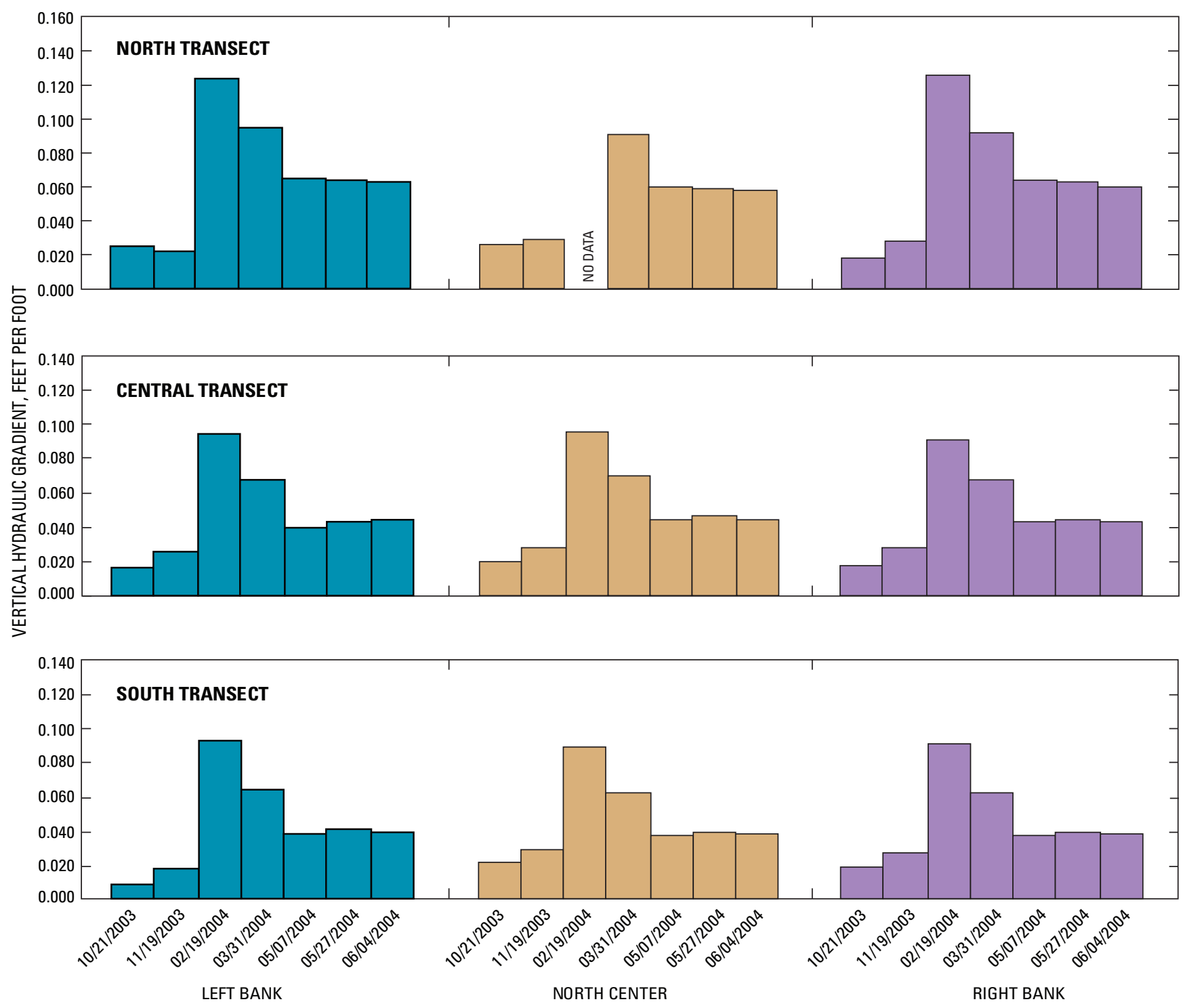

Figure 14. Seasonal variations in vertical hydraulic gradients in ground water at three piezometer transects across a drainage ditch tributary of Bertrand Creek, lower Nooksack River basin, Whatcom County, Washington, October 2003 to June 2004. 

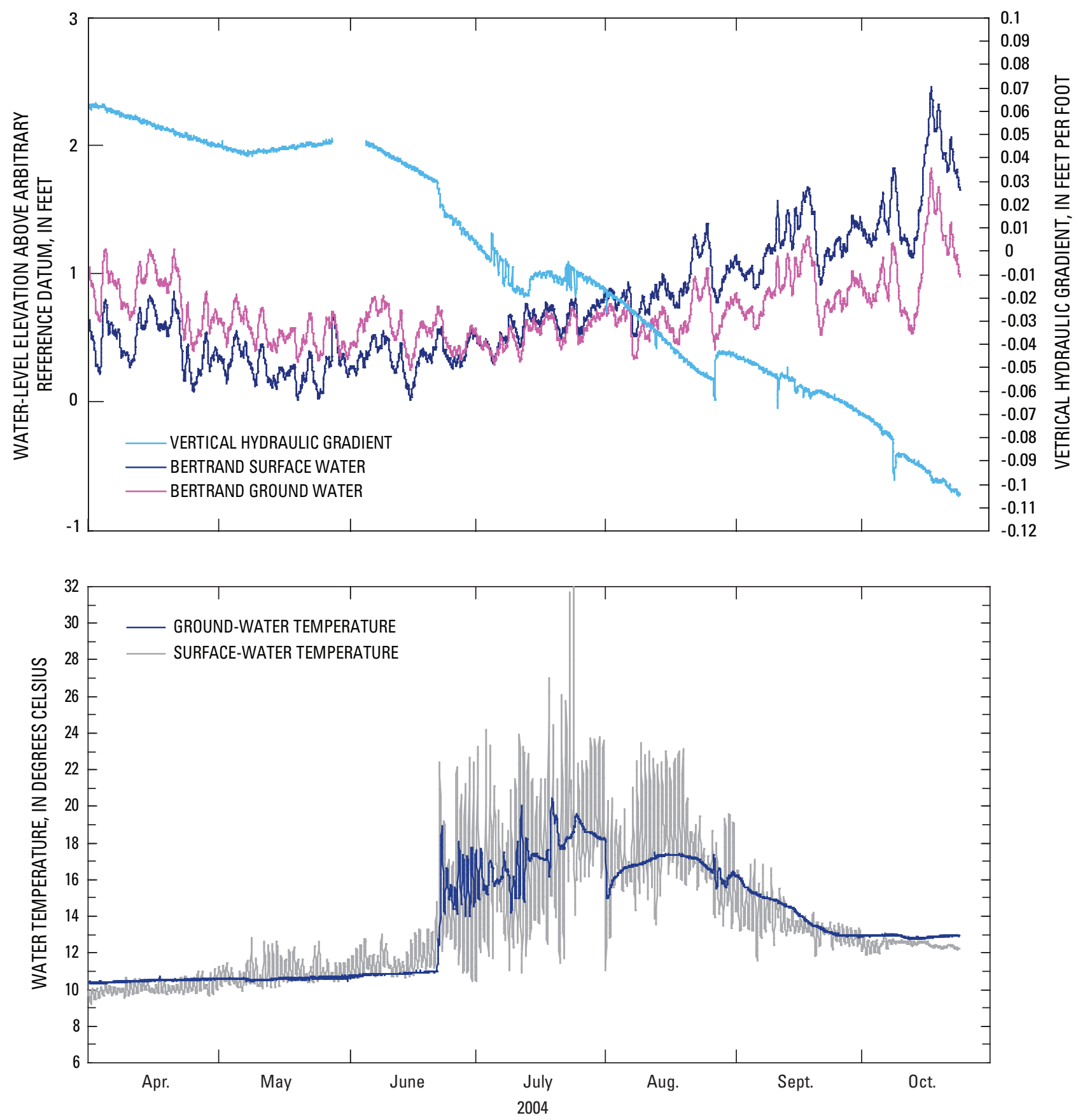

Figure 15. Continuous water level and vertical hydraulic gradient data and temperatures of surface water and ground water at a tributary to Bertrand Creek, lower Nooksack River basin, Whatcom County, Washington, April to October 2004. 


\section{Spatial and Temporal Variability}

Each of the ground-water discharge study sites examined in this study showed evidence that ground-water discharge is variable in both space and time. Spatial variability of ground-water discharge along the South Fork of the Nooksack River appears to be closely related to the geologic materials adjacent to the streambed. Coarse-grained alluvial fan and landslide deposits are likely in connection with the streambed and are therefore capable of contributing localized flow. In settings like Fishtrap Creek where geologic materials are more homogeneous, spatial variations are more subtle. Slightly larger vertical gradients were present in the upper parts of the drainage basin. Changes in topography or incision of the Fishtrap Creek streambed may cause localized downward flow from the creek that either remains in the hyporheic zone or recharges the aquifer. Variations in vertical hydraulic gradients at ground-water discharge study sites on Fishtrap and Fourmile Creeks suggest differences from one field to the next or from one side of the stream to the other. Such differences may be due to local site conditions such as topography, tile drains, or even wildlife, such as beaver dams.

Temporal variability was more pronounced at each site. Vertical hydraulic gradients generally were upward in the winter and diminishing through the spring and summer. In the late summer, especially during drought conditions, sites, such as Fishtrap and Bertrand Creeks, may have downward vertical hydraulic gradients for a period of time until the next rainy season. Flood events were found to temporarily reverse the flow of water across the streambed as surface-water levels exceed local ground-water levels. During these short-duration events, surface water recharges the aquifer or is held in bank storage until the flood crest passes.

The spatial and temporal variability of surface water/ ground-water interactions strongly influence the movement of contaminants into and out of the surface-water system.

\section{Quality of Ground Water Discharging to Streams}

\section{Bacteria}

In this study, E. coli bacteria were rarely detected in samples of ground water discharging to streams in the Nooksack River lowland. E. coli were detected in 9 of 145 ground-water samples analyzed and concentrations of $E$. coli in ground water typically were much lower than concentrations of $E$. coli in the overlying surface water. Additionally, when E. coli was detected in ground water, it usually was detected in only one or two of the six to nine ground-water samples collected at a given site. However, E. coli were detected in all samples of surface water from the Nooksack River, Fishtrap and Fourmile Creeks, and the tributary to Bertrand Creek at concentrations ranging from 2 to $5,000 \mathrm{CFU} / 100 \mathrm{~mL}$. Comparison of the concentration of $E$. coli in surface-water and ground-water samples collected from the ground-water discharge monitoring sites is shown in figure 16. The near absence of $E$. coli in samples of discharging ground water indicate that ground water discharging to lowland streams of the Nooksack River basin through the streambed is not likely the primary source of fecal contamination observed in those surface waters.

Surface-water monitoring data indicated that large concentrations of fecal coliforms were more common in surface-water samples collected during the spring and summer growing period when manure application to fields was routine, than in samples collected in the autumn and winter (Northwest Indian College, 2004). Additional ground-water samples were collected for analysis of E. coli at the ground-water discharge study site on the tributary to Bertrand Creek, which is essentially a drainage ditch bisecting a dairy pasture on which manure was regularly applied. During the early part of May 2004, manure was applied to the field west of this drainage ditch by field spray method and to the field east of the ditch by direct injection. Samples of discharging ground water were collected from all nine piezometers during the next significant rain event that followed. Ground-water samples were collected on May 27, 2004, when more than 1 in. of rain was recorded. Although E. coli was not detected in any of the ground-water samples; the concentration of $E$. coli in surface water on May 27, 2004, was 3,470 CFU/100 mL. About one-half of the piezometers sampled on May 27 showed a significant increase in specific conductance which may be related to the rain event. Prior to the rain event, E. coli concentrations in surface water were $18 \mathrm{CFU} / 100 \mathrm{~mL}$. An additional round of samples was collected 1 week later (June 4) and E. coli again was not detected in the ground-water samples although the surfacewater concentration of $E$. coli was $30 \mathrm{CFU} / 100 \mathrm{~mL}$. Clearly, fecal bacteria were being transported to the surface water at the time of the rain event although not through the groundwater pathway sampled by the piezometers.

Concentrations of $E$. coli also were determined for samples of surface water and ground water collected from the nine network piezometers along Fishtrap Creek (fig. 17). E. coli was detected in all surface-water samples at concentrations ranging from 350 to more than 1,000 CFU/ $100 \mathrm{~mL}$, but not in the ground-water samples where vertical hydraulic gradient and other water-quality data indicated ground water was discharging through the streambed. 


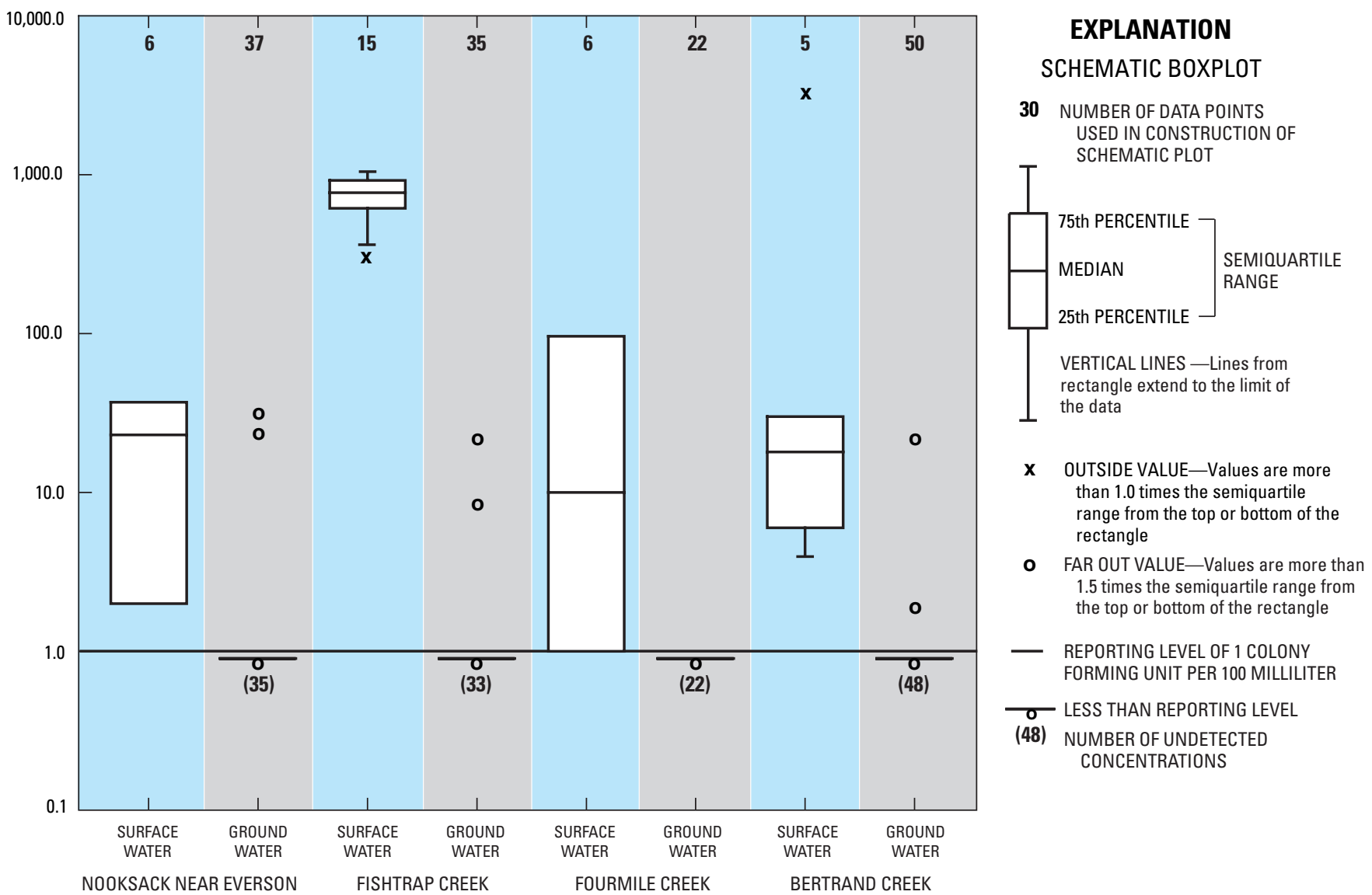

Figure 16. Concentrations of $E$. coli in surface water and discharging ground water of the Nooksack River lowland, Whatcom County, Washington.

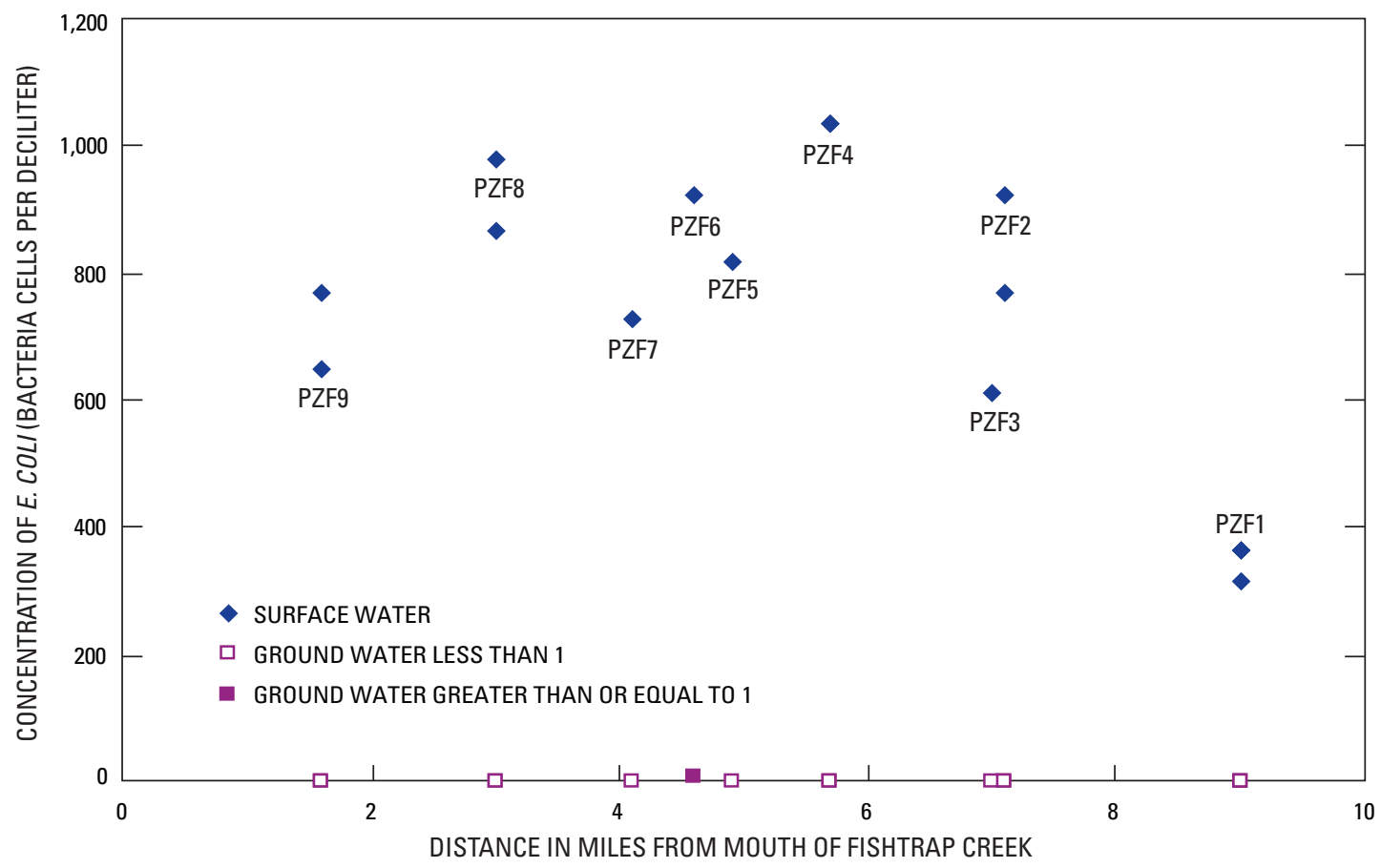

Figure 17. Concentrations of E. coli in surface water and discharging ground water from network piezometers along Fishtrap Creek, lower Nooksack River basin, Whatcom County, Washington. 
At one piezometer (PZF-6), where measurement of the vertical hydraulic gradient indicated that water from the stream was recharging the ground-water system, $E$. coli bacteria were detected at concentrations of 0 to $6 \mathrm{CFU} / 100 \mathrm{~mL}$ in ground water. The presence of $E$. coli in these ground-water samples likely is due to the advective transport of bacteria contained in stream water that is recharging the ground-water system. However, the in-stream piezometer at this site had to be re-installed on each visit. Thus, the measured bacteria could potentially be the result of recent disturbance of the streambed sediments or because the piezometer was exposed to bacteria in the surface water during re-installation.

At the most upstream site (PZF-1; 9 mi upstream of the mouth of Fishtrap Creek) near the border between the United States and Canada, the concentration of E. coli in streamflow generally was less than one-half of that measured in streamflow at downstream sites. The pattern of increased fecal coliform bacteria present in streamflow between piezometers PZF-1 and PZF-3 also was detected in periodic monitoring conducted biweekly between 2002 and 2004 by Northwest Indian College (2004). The 2 years of monitoring data show that concentrations at the downstream site were larger than concentrations at the upstream site about 78 percent of the time. Short-term variation in bacterial concentration data from stream-water samples is site dependent and may exceed an order of magnitude (Morace and Mckenzie, 2002). The typical pattern of larger concentrations measured at piezometer PZF-2 than PZF-1 indicates a source of fecal bacteria between the two piezometers.

The source of the increase in fecal bacteria detected in surface-water samples from Fishtrap Creek at these two sites is not well documented. The lack of substantial concentrations of E. coli in samples of ground water discharging through the streambed of this reach indicates that at the ground-water discharge study site, ground water is not the contamination pathway. Physical filtration is a major factor limiting the transport of bacteria in the ground-water system. The size of E. coli bacteria on cells typically is 0.5 to 2 microns, thus, they are on the order of clay-size particles. However, they typically are sorbed to clay particles or clustered in clumps, so they are effectively larger and can be readily trapped within the pore space of silty and sandy soils. Movement of bacteria through soils is thought to occur primarily from preferential flow processes (Smith and others, 1985; Abu-Ashour and others, 1998).

Other pathways that might introduce fecal contamination in this reach include overland flow during storm events that deposit large concentrations of bacteria in streambed sediments and discharge from subsurface tiles drains, which have been shown to be a significant pathway for fecal bacteria. Large precipitation events in the area contribute significant overland flow to the portions of Fishtrap Creek (fig. 18). Streambed sediments may provide a long-term refuge for fecal coliform bacteria. Soils in the areas adjacent to this reach of Fishtrap Creek are mapped as 'Artificially Drained' (U.S. Department of Agriculture, 1992). Fecal bacteria present in subsurface tile drainage is well documented (Patni and others, 1984; Dean and Foran, 1992; Goehring and others, 1999; Jamieson and others, 2002) and tile drainage can represent an important avenue for the transport of bacteria to surface-water systems (Hunter and others, 2000). If artificial drainage is a significant pathway for bacteria transport to surface waters; the use of controlled drainage (implemented to reduce the flux of nutrient to surface water) also may provide a management strategy to reduce bacteria loading by promoting attenuation and die-off of fecal coliforms. Fleming and MacAlpine (1995) showed that drains closed for 1 week would reduce bacteria loading from tile drainage discharge.

Only three samples of drainage discharge were obtained and $E$. coli were not detected in any of the three samples. Locations where isolated samples of discharge from tile drains could be collected were extremely limited because at times when drains were discharging, drain outlets were often submerged in the receiving surface-water body and isolated samples of drain discharge could not be obtained. Drainage samples were obtained from a drain line discharging at the Fourmile Creek site. The area being drained included a substantial amount of peat and organic soils and thus, soil permeabilities were low and likely created conditions where increased filtration of bacteria limited the transport of bacteria. Fecal contamination in streamflow originating from subsurface tile drains may still be an issue. Adequate sampling of drains was not accomplished because suitable drains were not available. Streambed sediments may provide a refuge for fecal coliform like E. coli and be a source of the bacteria measured in samples of streamflow. Precipitation events that result in large overbank flows such as shown in figure $18 \mathrm{~B}$ result in large influx of sediment from adjacent fields. If fecal bacteria are present on the surface of fields inundated by flood waters they could be transported to streambed sediments as flood waters recede and reside there for some time.

In areas of fecal contamination, concentrations of $E$. coli and fecal coliform are reported to be larger in bed sediments than in overlying water (Lewis and others, 1986; Burton and others, 1987; Irvine and Pettibone, 1993; Whitman and Nevers, 2003). Eight samples of water and sediment were collected from Fishtrap Creek at piezometer PZF-3 in a manner similar to a cross section. E. coli concentrations measured in the sediments ranged from 9 to 5,000 CFU/g dry sediment, while $E$. coli concentrations in stream water ranged from only 127 to $463 \mathrm{CFU} / 100 \mathrm{~mL}$. The smaller concentrations of $E$. coli in the sediment samples were in the sandy coarser grained material. 
A laboratory microcosm experiment evaluated the attenuation of $E$. coli bacteria in streambed sediments of Fishtrap Creek. Recent monitoring of fecal contamination in Fishtrap Creek and other creeks of the Nooksack River lowlands has shown persistent occurrence of fecal coliform throughout the year with typically the highest concentrations in the summer months (Northwest Indian College, written commun., 2003). The purpose of the attenuation experiment was to determine if significant numbers of fecal bacteria washed into streams during a winter storm event (fig. 18B), could remain viable in the streambed sediments until the following summer and when, if remobilized, they could contribute to the fecal coliform detected in samples of stream water.

Sediments used in the microcosm study were collected near piezometer PZF-3. The initial sediment $E$. coli concentration of these sediments was $144 \mathrm{CFU} / \mathrm{g}$ dry sediment, which was considered low for use in an attenuation

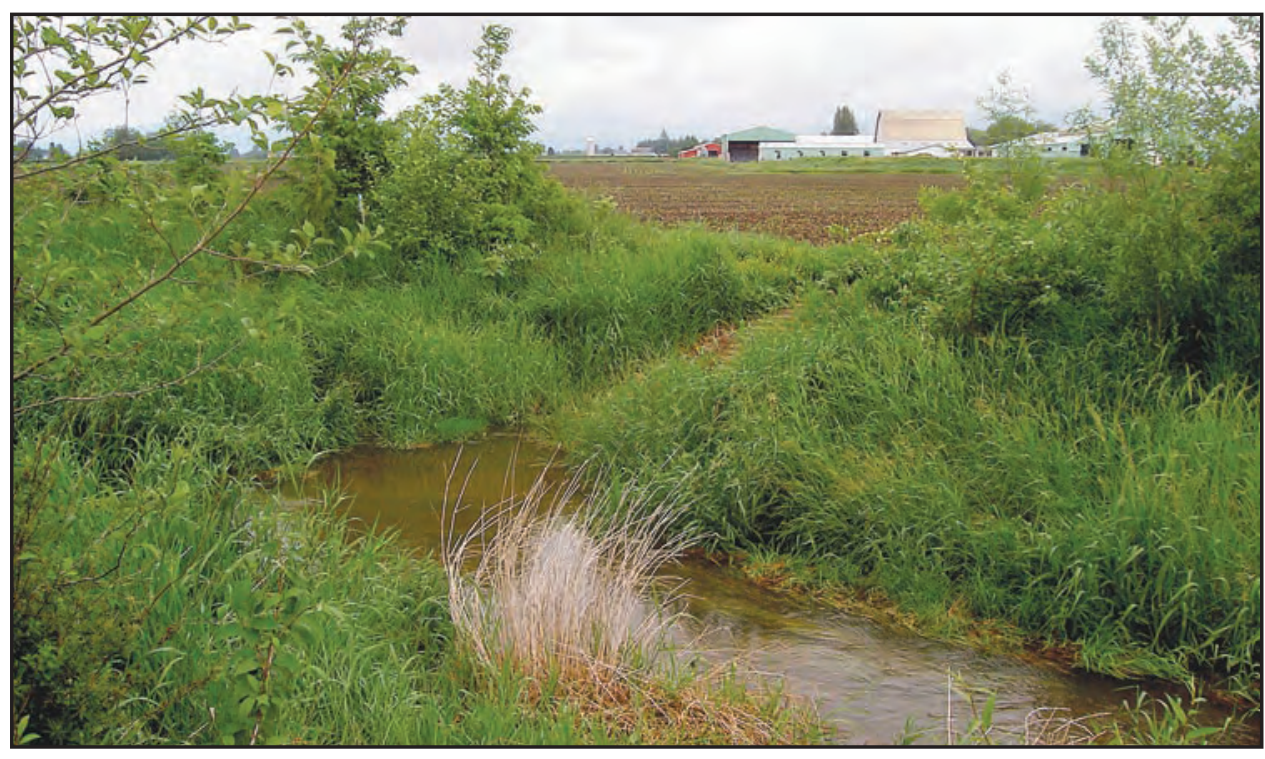

\section{A. Fishtrap Creek at normal flow.}

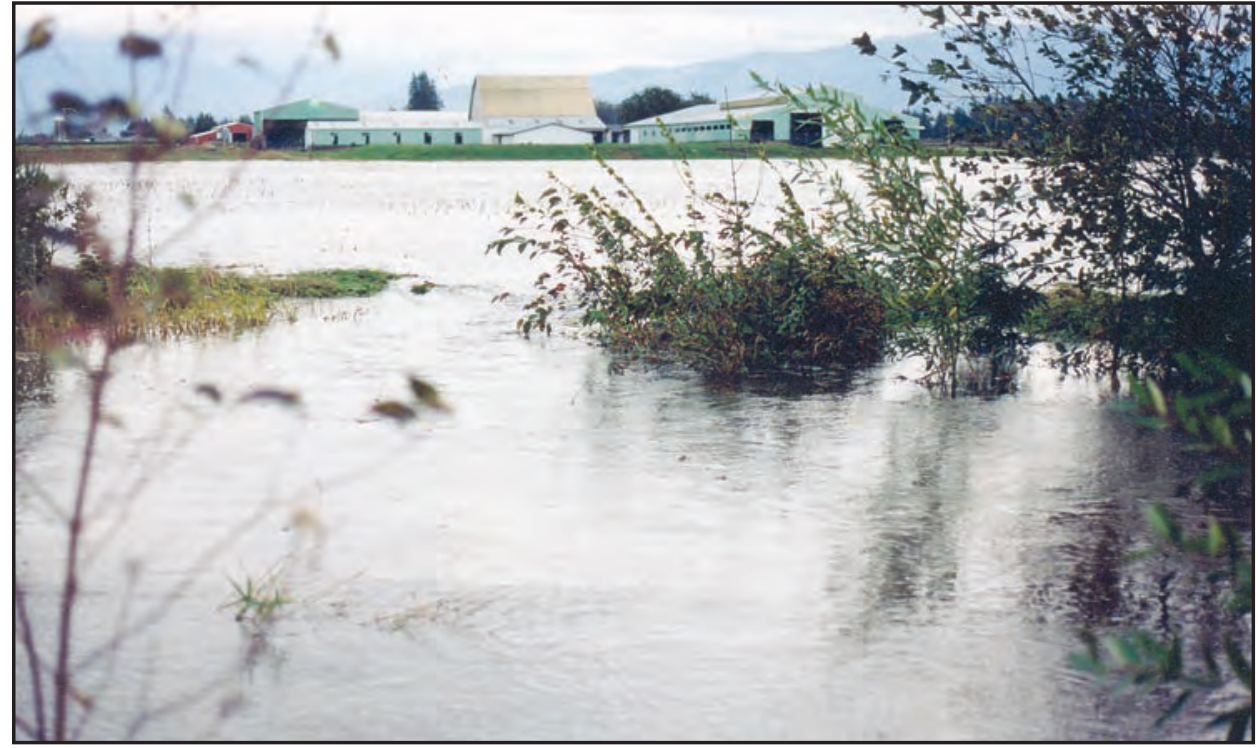

B. Fishtrap Creek at overbank flow.

Figure 18. Fishtrap Creek at normal flow and overbank flow during the October 19, 2003, precipitation event, lower Nooksack River basin, Whatcom County, Washington. 
study. Three liters of fresh dairy barnyard manure slurry containing about 20 percent solids was added to the 8 liters of sediment used in the experiment. Following the manure amendment, the initial E. coli concentration in sediment was $355,000 \mathrm{CFU} / \mathrm{g}$ dry sediment. E. coli concentrations in sediment decreased throughout the duration of the 101 day experiment until the concentration of $E$. coli in the final sample collected on day 101 was 186 CFU/g dry sediment; similar to the initial concentration in the unamended sediment. The rate of bacteria attenuation within the sediments was monitored by removing sediment samples from the microcosm and enumerating the E. coli concentrations on days 2, 4, 5, 12, $19,30,37,40,53,58,65,98$, and 101 of the experiment.

The sediment $E$. coli population concentrations plotted over time (fig. 19) shows a general pattern of exponential decay, particularly during the first 65 days where the regression line shows results in an exponential decay constant of 0.1025 per day with an $R^{2}$ of 0.9824 . The attenuation rate between 65 to 101 days was slower than during the first 65 days. The pattern of decreasing attenuation rates in the latter stage of attenuation studies has been reported in other bacteria attenuation studies (Hurst and others, 2002) and is often referred to as tailing. Tailing may result from the rapid die-off of more susceptible strains, which have larger attenuation constants, followed by a shift in the bacteria population distribution of the microbial community to strains that are hardier under the environmental conditions of the study.
This experiment showed that while some bacteria were able to survive for up to 100 days, more than 99.8 percent of the bacteria died-off during the first 65 days. Unless there was significant flow or disturbance that resulted in substantial resuspension of streambed sediments, the large concentrations of fecal bacteria measured in the streams of the study area during the late summer period are not likely to be derived from bacteria transported from field sediments during winter storms. The 65-day die off period measured in the microcosm suggests that very limited numbers of bacteria would survive in-stream for the 6-month period from March to August after the cessation of winter storm events, and would therefore not be a major contributor to high bacteria concentrations measured in August 2004.

The rate of bacteria die-off and attenuation changed over the course of the experiment as shown in the tailing in figure 19. The initial attenuation rates observed during the first week of the experiment were somewhat higher than the overall attenuation rate. Exponential decay constants can be converted to a 'time required for 50 percent attenuation' values that are synonymous to radioactive half-life constants. Decay constants, calculated for the initial concentration and each measurement, were converted to 'time to 50 percent concentration' and are plotted with the concentration data shown in figure 19. During the first week of the experiment, the 'time to 50 percent concentration values' increased from about 4.5 to about 6 days. In the following 8 weeks, the 'time to 50 percent concentration' ranged from 6 to 8 days and

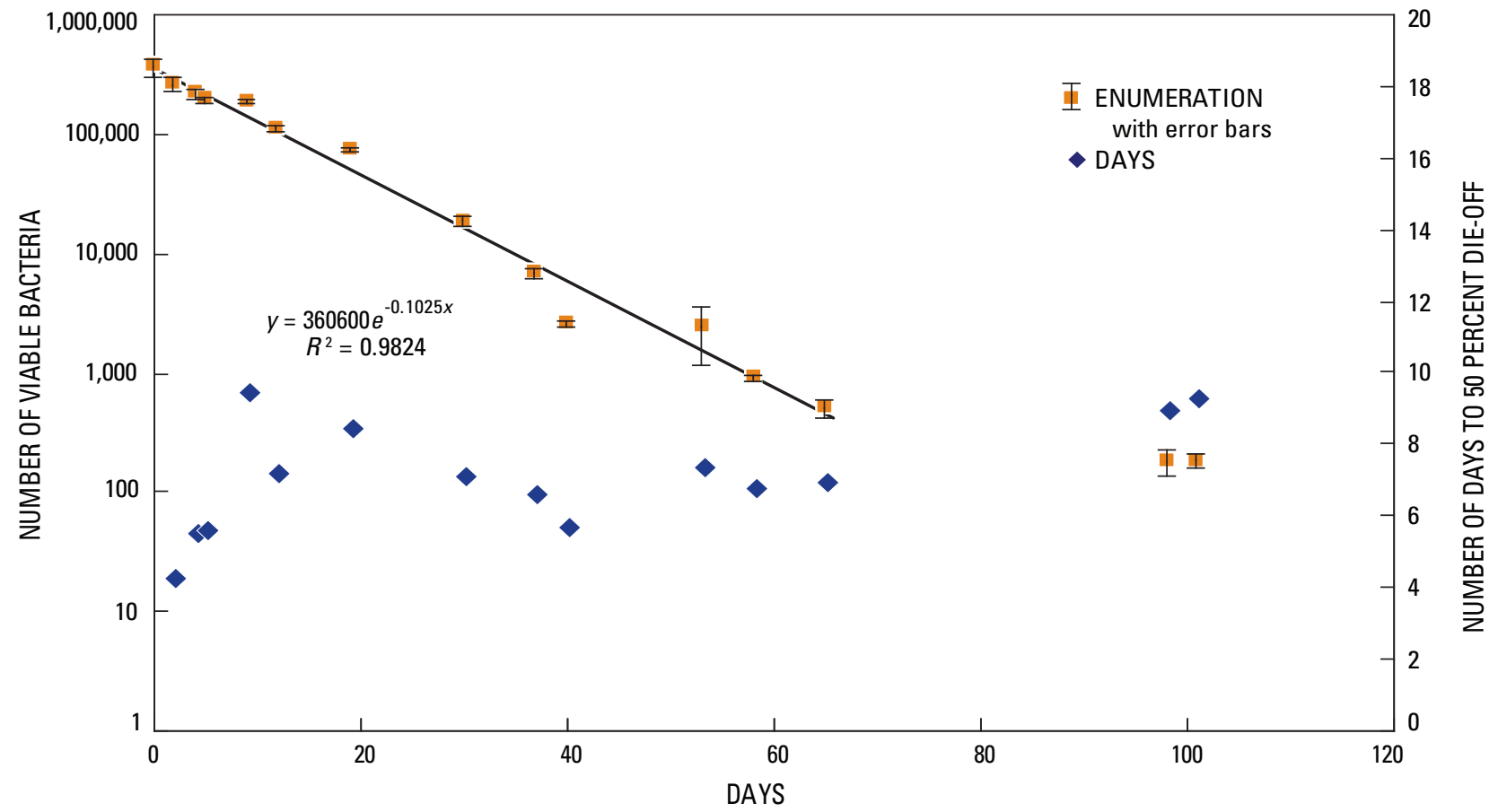

Figure 19. Concentration and rate of attenuation of E. coli in stream sediments amended with dairy manure. 
increased to 9 to 10 days in the final two measurements made in the $14^{\text {th }}$ week of the experiment. The change in attenuation rates indicate that the length of the attenuation experiment can have a measurable effect on the overall rate of attenuation. The use of streambed sediments amended with barnyard-manure slurry merits consideration when evaluating these results. Higher attenuation rates observed during the first week of the experiment may have occurred in the bacteria derived from a non-stream acclimated source.

Differences in attenuation rates determined for $E$. coli in this study and those determined in other studies are difficult to assess because of the differences in study designs. The decay rates measured in this study using manure amended sediments from Fishtrap Creek were higher than those reported by Sherer and others (1992), but lower than reported decay rates from Burton and others (1987) and Davies and others (1995). The membrane enclosed microcosm used by Davies and others (1995) resulted in faster attenuation as did the shorter duration of monitoring (14-day study) in the open flow system of Burton and others (1987). The attenuation rates determined by Sherer and others (1992) using a refrigerated 4-liter microcosm $\left(8^{\circ} \mathrm{C}\right)$ were substantially smaller than those determined in this study. Numerous factors control the attenuation of bacteria populations, including predation, sunlight, organic matter, and size of sediment grains. This microcosm study, which replicated to the extent possible known field conditions, showed that $E$. coli can reside in sediments of Fishtrap Creek for several weeks to months, but are reduced in number by more than 90 percent over the course of several months.

\section{Chemical Quality and Nitrate Degradation}

The concentrations of nitrate, ferrous iron, and dissolved oxygen were measured intermittently to characterize the quality of discharging ground water and to evaluate the potential for denitrification. Ground water discharging through streambeds in the Nooksack River lowlands typically was reducing; concentrations of dissolved oxygen and nitrate being absent or low, and often containing elevated concentrations of ferrous iron that exceeded $1 \mathrm{mg} / \mathrm{L}$. Although these concentrations are within the range measured in ground waters of the study area, they tend to be characteristic of a small fraction of the typical range (fig. 20). These data indicate that concentrations of water-quality constituents, particularly redox sensitive species, that are typical of ground water in the area may not be typical of concentrations that are being discharged to streams through the streambed.

The absence of nitrate in discharging ground water, and the consistent detection of reduced conditions in geochemical parameters at all study sites suggest that denitrification in ground water discharging through the sediments surrounding stream channels is widespread. To assess whether denitrification is contributing to the lack of nitrate detected in ground water at the study sites, relative concentrations of nitrogen and argon gas in ground water were examined.
Dissolved nitrogen and argon gases enter ground water through temperature dependent equilibration processes with the atmosphere at the time of recharge. Because these gases generally are unreactive in the ground-water system, the ratio of their concentration remains constant in ground water unless disrupted by additional gas sources such as those generated during denitrification. The amount of excess nitrogen gas in a sample of ground water can be used to estimate the quantity of nitrate reduced through denitrification to produce the excess nitrogen gas (Vogel and others, 1981).

The concentrations of dissolved nitrogen and argon gas were measured in 29 samples of ground water. Most samples were analyzed in duplicate and all concentration data are shown in tables 1-4 (at back of report). In the lower Nooksack River basin, the average temperature of recharging ground water in contact with the atmosphere is about $10^{\circ} \mathrm{C}$, but may range from 9 to $11^{\circ} \mathrm{C}$ ). The concentration of dissolved argon in ground water in equilibrium with the atmosphere at a groundwater temperature of $10^{\circ} \mathrm{C}$ is $0.67 \mathrm{mg} / \mathrm{L}$. Many of the samples showed anomalously low concentrations of argon, indicating that some gases were stripped from the samples, yielding measurements that were ambiguous with respect to estimates of denitrification. Ground-water samples that were found to contain less than the typical argon content, or with a relative difference between duplicate samples of more than 1 percent, were considered to be compromised (potentially having been stripped of some gases) and eliminated from consideration as indicators of denitrification.

Gas stripping likely occurred during the sampling process as the water was exposed to reduced hydrostatic pressures generated from the peristaltic pump used with small diameter tubing. Most samples from study sites at Fourmile and Fishtrap Creeks showed extensive gas stripping and were deemed unsuitable. About one-half of the samples collected from the Bertrand Creek and Fishtrap Creek sites were usable. The increased length of tubing needed to connect the piezometer point to the sampling pump at Fourmile and Fishtrap Creek sites likely increased the gas stripping occurrence at these sample sites.

"Excess air" commonly is found in ground-water samples and results in larger dissolved gas concentrations than would be expected based on air-water equilibration alone. Excess air occurs when additional quantities of atmospheric gases are incorporated into the ground water from air bubbles that become trapped in ground water during recharge (Heaton and Vogel, 1981). Figure 21 shows the solubility line for argon and nitrogen in ground water equilibrated with the atmosphere at temperatures from 5 to $30^{\circ} \mathrm{C}$ along with a line showing concentrations present in ground water at $10^{\circ} \mathrm{C}$ with 0 to 15 $\mathrm{mg} / \mathrm{L}$ of excess air. The shaded (grey) portion of the excess air line illustrates the range of argon and nitrogen concentrations that would be expected if 0 to $5 \mathrm{~cm}^{3} / \mathrm{L}$ of excess air are trapped in ground water recharging at $10^{\circ} \mathrm{C}$. Tesoriero and others (2000) reported concentrations of nitrogen and argon in aerobic ground water collected in the upper reaches of the Fishtrap Creek basin (near PZF-1 and PZF-3) that fell 


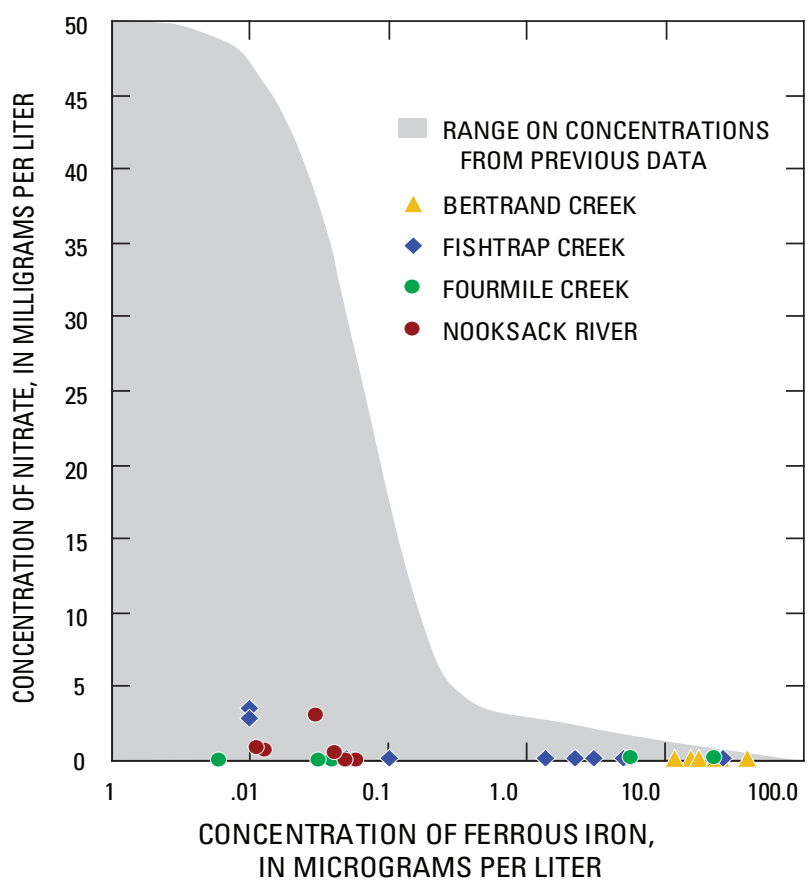

Figure 20. Nitrate and ferrous iron concentrations in discharging ground water, lower Nooksack River basin, Whatcom County, Washington. within the shaded grey area plotted in figure 21. Their data provides additional evidence that the concentrations of gases in the recharge to the Sumas aquifer are consistent with those detected in ground water for this study, and support an interpretation that conditions of excess air were present in ground water at some of the study sites. Two data points measured in ground water collected from Bertrand Creek plotted in figure 21 show evidence of excess gas incorporation. The points are shown adjacent and slightly above the excess gas solubility line.

Dissolved gas concentrations in ground water considered to be uncompromised are plotted in figure 21. Excess nitrogen gas (in the absence of excess argon gas), indicates denitrification, and was measured in ground-water samples from all study sites. Measurement points shown in figure 21 that plot horizontally to the right of the excess air recharging at the $10^{\circ} \mathrm{C}$ line indicate that excess nitrogen gas was detected in these samples. The concentrations of excess nitrogen gas varied by as much as $8 \mathrm{mg} / \mathrm{L}$ with typical concentrations of excess nitrogen gas of about 2 to $4 \mathrm{mg} / \mathrm{L}$. Two units of nitrate are reduced for each unit of nitrogen gas produced. Thus, the dissolved gas data suggest that from 4 to $8 \mathrm{mg} / \mathrm{L}$ and in some cases as much as $16 \mathrm{mg} / \mathrm{L}$ of nitrogen as nitrate in ground water have been denitrified.

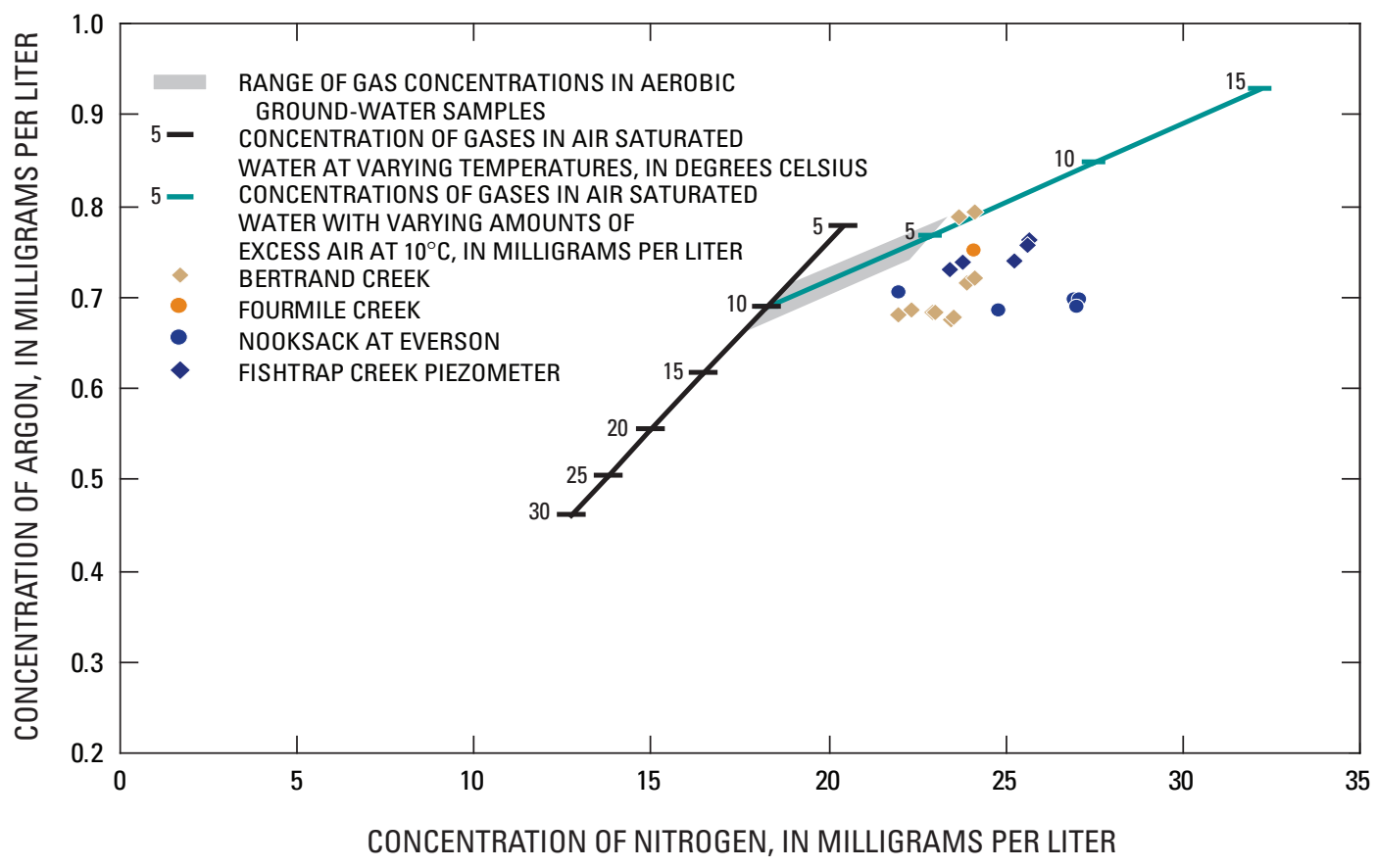

Figure 21. Dissolved argon and nitrogen concentrations in discharging ground water, lower Nooksack River basin, Whatcom County, Washington. 
Evidence of denitrification was observed at all samplecollection sites. Low dissolved-oxygen concentrations, and the presence of dissolved ferrous iron, suggest that the reducing conditions necessary for denitrification to proceed are present. The excess nitrogen gas detected in ground water at the Bertrand Creek and Nooksack River sites indicate that denitrification has generated nitrogen gas. Low concentrations of nitrate measured in surface water, and high concentrations reported in upgradient areas of the Sumas aquifer suggest that nitrate concentrations are reduced at some point along the ground-water transport pathway, before discharging to surface water. Puckett (2004) suggests that denitrification may not occur throughout much of the aquifer, but more likely takes place in the sediments and riparian areas surrounding streambeds, where reducing conditions are more common.

Some of the nitrate contamination present in ground water may not ultimately be transported to surface waters. In agricultural areas, nitrate concentrations in ground water commonly are larger than nitrate concentrations in surface water (Mueller and others, 1995; Bohlke and others, 2001). In an area of the South Platte River system where McMann and Bohlke (2000) found that the load of nitrate measured in surface water was about 70 percent less than expected based on input of ground water from the adjacent area; with about one- half of the deficit being attributed to denitrification. In the Nooksack River lowlands, the median nitrate concentrations in surface water for Fishtrap Creek (1995 to 1998) was reported to be $2.8 \mathrm{mg} / \mathrm{L}$ (Embrey and Frans, 2003). Fistrap Creek drains much of the Sumas aquifer in which the median nitrate concentration of ground water was substantially larger than $3.8 \mathrm{mg} / \mathrm{L}$ (1991-1993) as reported by Cox and Kahle (1999). Although the sampling periods for surface and ground water from the Nooksack River lowlands were not coincident, nitrate concentrations in ground water of the Sumas aquifer have been reported to be increasing (Kaluarachchi and Almasri, 2002), thus there may be a similar trend of lower than expected surface water nitrate load as described by McMann and Bohlke (2000) for the South Platte River.

\section{Summary and Conclusions}

Elevated concentrations of fecal bacteria and nitrate in lowland streams have created significant environmental problems in the lower Nooksack River basin of Whatcom County, Washington. A study was conducted to evaluate if ground water was a pathway for contamination to enter surface water streams and to better understand the processes that affect attenuation and degradation of those contaminants at or near the ground water/surface water interface.

Reconnaissance surveys were conducted to identify locations of ground-water discharge and four sites were selected in order to evaluate spatial and temporal variability of groundwater discharge in differing settings and scales within the lowland. The information learned at each of the study sites contribute to a better understanding of ground-water/surface water interactions and contaminant transport, which will assist water-resources managers in making better informed decisions.

The reconnaissance survey of the South Fork of the Nooksack River revealed that spatial variability of groundwater discharge is closely related to the geologic materials adjacent to the streambed. When the streambed encounters various geologic materials with differing aquifer properties, a greater degree of variability in ground-water discharge can be expected. However, small-scale variability also can be seen at a more local scale, even when geologic materials are more homogeneous. Ground-water discharge study sites on Fishtrap Creek and Fourmile Creek revealed small-scale variations from one field to the next or from one side of the stream to the other. Such differences may be due to local site conditions such as topography, tile drains, or other impacts like dredging or beaver dams.

Temporal variations in ground-water discharge were much more pronounced. At the mainstem of the Nooksack River near Everson and at Fishtrap Creek, ground-water discharge to surface water was nearly continuous throughout most of the year, except during winter storm events. High river stages caused temporary reversals in vertical hydraulic gradients that lasted for several hours during peak high water conditions. At all ground-water discharge study sites, upward vertical hydraulic gradients varied seasonally with generally more positive gradients in the winter and less positive gradients in the late summer. However, temporary reversals in vertical hydraulic gradients were observed at Fishtrap Creek and the tributary of Bertrand Creek. At these sites, the gradient reversed from positive (ground-water discharge) to negative (ground-water recharge) during the late summer, the driest time of the year. The return to a positive gradient (ground-water discharge) occurred during the autumn shortly after the first rains of the winter wet season. At each of the ground-water discharge study sites, ground-water levels closely mimicked surface-water levels while maintaining a nearly constant hydraulic head difference. This suggests that hydrostatic pressure effects resulting from changing river stage are rapidly transmitted through the streambed even though actual flow of water may be somewhat slower.

Water-quality samples were collected at each of the ground-water discharge study sites in order to better understand bacteria transport and denitrification processes. Although E. coli bacteria were detected in all samples of surface water, it was only detected in a few samples of ground water. This suggests that fecal coliform and E. coli bacteria are effectively removed during ground-water transport before being discharged into the streams. Increasing concentrations of bacteria at downstream sample sites suggests that there may be inputs of contamination between sampling sites. Alternative pathways for bacteria input include overland flow such as the flood event observed on October 19, 2003 and discharge from tile drains. The level of contaminants introduced from tile drains could not be adequately addressed 
in this study. Because tile drains are difficult to locate and their outlets are often submerged in the stream only three samples were collected, none of which had detectable bacteria concentrations.

The ability of streambed sediments to provide refuge for bacteria was addressed by conducting a laboratory microcosm experiment. The experiment showed that although some bacteria are able to survive for as many as 100 days, more than 99.8 percent died off during the first 65 days. The experiment suggests that overland flow events (floods) during winter months are not the likely cause of high bacteria concentrations in late summer months.

Nitrate contamination of ground water is a well documented problem in the Nooksack River lowland. Although median concentrations of nitrate in ground water are $3.8 \mathrm{mg} / \mathrm{L}$, concentrations in discharging ground water were much lower or absent. Low levels of dissolved oxygen and elevated concentrations of ferrous iron indicate that reducing conditions adjacent to the streambed are sufficient for denitrification to occur. Concentrations of dissolved nitrogen and argon were measured to confirm the presence of excess nitrogen, the end-product of denitrification. In spite of gas-stripping, excess nitrogen gas appears to be present in most samples suggesting that nitrate is being degraded before discharging to surface water. Concentrations of dissolved argon and nitrogen gas measured in samples of ground water indicated that typically 4-8 mg/L and in come cases as much as $16 \mathrm{mg} / \mathrm{L}$ nitrogen as nitrate in ground water is denitrified prior to its discharge to surface water.

Data from this study will help water-resources managers focus on effective management strategies for reducing contaminant levels in surface water streams of the Nooksack River lowland. The lack of significant contaminants in discharging ground water and the fact that surface-water contaminant levels increase between some sampling points suggests that there are alternative pathways for contamination to enter streams.

Subsurface tile drains that have been installed beneath some agricultural fields could provide a network of preferential flow paths to surface water and have been shown to be a source of fecal contamination in surface waters in other areas. This study was unable to adequately address this question for the lowland streams of the Nooksack River basin. However, if drains are determined to be a significant source of bacteria in these streams, they also may provide a mechanism to mitigate the problem in areas where they are present. Engineering controls such as a gate valve on the outlet of the drain pipe may provide a mechanism to regulate the transport of bacteria and other contaminants. Controlling the rate of drainage could allow more time for natural die-off process to reduce bacteria concentrations while helping to provide additional ground-water discharge during late summer minimum flow conditions. In addition, controlled drainage also may allow more time for natural denitrification processes to occur thus, improving the quality of water entering the stream.

\section{References Cited}

Abu-Ashour, J., Joy, D.M., Lee, H., Whiteley, H.R., and Zelin, S., 1998, Movement of bacteria in unsaturated soils columns with macropores: Transactions of the American Society of Agricultural Engineers, v. 41, p. 1043-1050.

American Public Health Association, American Water Works Association, and Water Pollution Control Federation, 1998, Standard methods for the examination of water and wastewater (20th ed.): Washington, D.C., American Public Health Association, p. 1205.

Bitton, Gabriel, and Harvey, R.W., 1992, Transport of pathogens through soils and aquifers, in Mitchell, Ralph (ed.), Environmental Microbiology: New York, Wiley-Liss Inc., p. 103-124.

Bohlke, J.K., Wanty, R., Tuttle, M., Delin, G., and Landon, M., 2002, Denitrification in the recharge area and discharge area of a transient agricultural nitrate plume in a glacial outwash sand aquifer, Minnesota: Water Resources Research, v. 38, no. 7, p. 10-1 to 10-26.

Burton, G.A., Gunnison, D., and Lanza, G.R., 1987, Survival of pathogenic bacteria in various freshwater sediments: Applied and Environmental Microbiology, v. 53, p. 633638.

Carey, B.M., 2002, Effects of land application of manure on groundwater at two dairies over the Sumas-Blaine surficial aquifer-Implications for Agronomic Rate Estimates: Washington Department of Ecology, Publication No. 0203-007, Olympia, Washington, 75 p. plus appendixes. URL: http://www.ecy.wa.gov/pubs/0203007.pdf, accessed June 2005.

Chapelle, F.H., 1993, Ground-water microbiology and geochemistry: New York, John Wiley and Sons, 424 p.

Cox, S.E., and Kahle, S.C., 1999, Hydrogeology, ground-water quality, and sources of nitrate in lowland glacial aquifers of Whatcom County, Washington, and British Columbia, Canada: U.S. Geological Survey Water-Resources Investigations Report 98-4195, 251 p., 5 pls.

Craun, G.F., 1986, Waterborne Diseases in the United States: CRC press, Boca Raton, Florida, 295 p.

Davies, C.M., Long, J.A.H., Donald, M., and Ashbolt, N.J., 1995, Survival of fecal microorganisms in marine and freshwater sediments: Applied and Environmental Microbiology, v. 61, p. 1888-1896.

Dean, D.M., and Foran, M.E., 1992, The effect of farm liquid waste application on tile drainage: Journal of Soil and Water Conservation, v. 5, p. 368-369.

Defawe, R.M., 2003, Attenuation of fecal coliforms and Escherichia coli in the Nooksack River Basin stream sediments, Whatcom County, Washington: University of Washington Thesis, $111 \mathrm{p}$.

Embrey, S.S., 2001, Microbiological quality of Puget Sound Basin streams and identification of Contaminant sources: Journal of the American Water Resources Association, v. 37 , no. 2 , p. $407-421$. 
Embrey, S.S., and Frans, L.M., 2003, Surface-water quality of the Skokomish, Nooksack, and Green-Duwamish Rivers and Thorton Creek, Puget Sound Basin, Washington, 1995-1998: U.S. Geological Survey Water-Resources Investigations Report 02-4190, 182 p.

Erickson, Denis, 1998, Sumas-Blaine surficial aquifer nitrate characterization: Washington State Department of Ecology, Publication No. 98-310, Olympia, Washington, 27 p. plus appendixes.

Erickson, Karol, 1995, Fishtrap Creek total maximum daily load study, June 1995: Washington State Department of Ecology, Publication No. 95-328, Olympia, Washington, $26 \mathrm{p}$.

Fishman, M.J. [ed.], 1993, Methods of analysis by the U.S. Geological Survey National Water Quality Laboratory; determination of inorganic and organic constituents in water and fluvial sediments: U.S. Geological Survey Open-File Report 93-125, 217 p.

Fishman, M.J., and Friedman, L.C., [eds.], 1989, Methods for determination of inorganic substances in water and fluvial sediments: U.S. Geological Survey Techniques of WaterResources Investigations, Book 5, Chapter A1, 545 p.

Fleming, R.J., and MacAlpine, M.C,, 1995, Plugging tile drains to reduce manure contamination: Canadian Society of Agricultural Engineering Paper 95-512, Saskatoon, Saskatchewan, $12 \mathrm{p}$.

Garland, D. P., and Erickson, Denis, 1994, Ground water quality survey near Edaleen Dairy, Whatcom County, Washington, January 1990-April 1993: Washington State Department of Ecology, Olympia, Washington, Publication No. 94-37, 20 p. plus appendixes.

Gartner-Lee, 1993, Fraser Valley Groundwater Monitoring Program Phase 1 Report: British Columbia Ministry of Health, Victoria, British Columbia, 51 p.

Goehring, L.D., Wright, P.E., Steenhuis, T.S., and Walter, M.F., 1999, Fecal coliforms in tile drainage effluent: American Society of Agricultural Engineers Paper No. 992203, St. Joseph, Missouri, 22 p.

Hancock, D.D., Besser, T.E., Kinsel, M.L., Tarr, P.I., Rice, D.H., and Paros, M.G., 1994, The prevalence of Escherichia coli $\mathrm{O} 157: \mathrm{H} 7$ in dairy and beef cattle in Washington State: Epidemiology and Infection, v. 113, no. 2, p. 199-207.

Heaton, T.H.E., and Vogel, J.C., 1981, "Excess air" in ground water: Journal of Hydrology, v. 50, p. 201-216.

Hii, B., Liebscher, H., Mazalek, M., and Tuominen, T., 1999, Ground water quality and flow rates in the Abbotsford Aquifer, British Columbia: Aquatic and Atmospheric Sciences Division, Environmental Conservation Branch, Environment Canada, Pacific and Yukon Region, Vancouver, British Columbia, 38 p.

Hunter, C., Perkins, J, Tranter, J., and Hardwick, P., 2000, Fecal bacteria in the waters of an upland area in Derbyshire, England: the influence of agricultural land use: Journal of Environmental Quality, v. 29, no. 4, p. 1253-1261.
Hurst, C.J., Crawford R.L., Knudsen, G.R., McInerney, M.J., and Stetzenbach, L.D., 2002, Modeling the fate of microorganisms in water, wastewater, and soil: Manual of environmental microbiology, second edition, ASM Press, Washington, DC. p. 300-308.

Hussein, H.S., and Sakuma, T, 2005, Prevalence of Shiga toxin-producing Escherichia coli in dairy cattle and their products: Journal of Dairy Science, v. 88, p 450-465.

Inkpen, E.L., Tesoriero, A.J., Ebbert, J.C., Silva, S.R., and Sandstrom, M.W., 2000, Ground-water quality in regional, agricultural, and urban settings in the Puget Sound Basin, Washington and British Columbia, 1996-1998: U.S. Geological Survey Water-Resources Investigations Report 00-4100, 66 p.

Irvine, K.N., and Pettibone, G.W., 1993, Dynamics of indicator bacteria populations in sediment and river water near a combined sewer outfall: Environmental Technology, v. 14 , p. 531-542.

Jamieson, R.C., Gordon, R.J., Sharples, K.E., Stratton, G.W., and Madani, A., 2002, Movement and persistence of fecal bacteria in agricultural soils and subsurface drainage water-A review: Canadian Biosystems Engineering. v. 44, p. 1.1-1.9.

Joy, D.M., Lee, H., Reaume, C.M., Whitely, H.R., and Zelin, S., 1998, Microbial contamination of subsurface tile drainage water from field applications of liquid manure: Canadian Agricultural Engineering, v. 40, no. 3, p. 153-160.

Joy, Joe, 2000, Lower Nooksack River basin bacteria total maximum daily load evaluation: Olympia, Washington, Washington State Department of Ecology, Publication No. 00-03-006,, 60 p. plus appendixes.

Kaluarachchi, J.J., and Almasri, M.N., 2002, Conceptual model of fate and transport of nitrate in the Sumas-Blaine aquifer, Whatcom County, Washington: Logan, Utah, Draft Report: Utah Water Research Laboratory, Utah State University, $234 \mathrm{p}$.

Kimbrough, R.A., Wiggins, W.D., Smith, R.R., Ruppert, G.P., Knowles, S.M, and Renslow, V.F., 2004, Water resources data, Washington, water year 2003: U.S. Geological Survey Water-Data Report WA-03-1, 547 p.

Korom, S.F., 1992, Natural denitrification in the saturated zone: a review: Water Resources Research, v. 28, p. 16571668.

Lee, D.R., Geist, D.R., Saldi, Kay, Harwig, Dale, and Cooper, Tom, 1997, Locating ground-water discharge in the Hanford Reach of the Columbia River: Richland, Washington, Pacific Northwest National Laboratory, PNNL-11516, 37 p.

Lewis, G.D., Austin, F.J., and Loutit, M.W., 1986, Enteroviruses of human origin and fecal coliforms in river water and sediment downstream from a sewage outfall in the Taiere River, Otago: New Zealand Journal of Marine and Freshwater Research, v. 20, p. 101-105.

Liebscher, H., Hii, B., and McNaughton, D., 1992, Nitrates and pesticides in the Abbotsford Aquifer, southwestern British Columbia: Environment Canada, Pacific and Yukon Region, Vancouver, BC. 
McMahon, P.B., and Bohlke, J.K., 1996, Denitrification and mixing in a stream-aquifer system: effects on nitrate loading to surface water: Journal of Hydrology, v. 196, p. 106-128.

Morace, J.L., and McKenzie, S.W., 2002, Fecal-indicator bacteria in the Yakima River Basin, Washington-An examination of 1999 and 2000 synoptic-sampling data and their relation to historical data: U.S. Geological Survey Water-Resources Investigations Report 02-4054, 32 p.

Mueller, D.K., Hamilton, P.A., Helsel, D.R., Hitt, K.J., and Ruddy, B.C. (1995), Nutrients in ground water and surface water of the United States-An analysis of data through 1992: U.S. Geological Survey, Water Resources Investigation Report 95-4031, 74 p.

Myers, D.N., and Sylvester, M.D., 1997, National field manual for the collection of water-quality data-Biological indicators: U.S. Geological Survey Techniques of WaterResources Investigations, book 9, chap. A7, 38 p.

Nataro, J. P., and Kaper, J. B., 1998, Diarheagenic Escherichia coli: Clinical Microbiological Reviews, v. 11, p. 142-201.

Northwest Indian College, 2004, Final Report TMDL Implementation Monitoring in WRIA 1 Project March 1, 2002 through February 28, 2004: Bellingham, Washington, Northwest Indian College.

Patni, N.K., Toxopeus, R., and Hore, F.D., 1984, Bacterial quality of tile drainage water from manured and fertilized cropland: Water Research, v. 18, p. 127-132.

Petridis, H., Kidder, G., and A. Ogram, 2002, E. coli 0157: H7 A Potential Health Concern: Fact-Sheet SL-146 Florida Cooperative Extension Service; Institute of Food and Agricultural Sciences, University of Florida. URL: http:// edis.ifas.ufl.edu/SS197, accessed October 2005.

Puckett, L.J., 2004, Hydrogeologic controls on the transport and fate of nitrate in ground water beneath riparian buffer zone: results from thirteen studies across the United States: Water Science and Technology, v. 49, n. 3, p. 47-53.
Simonds, F.W., Longpré, C.I., and Justin, G.B., 2004, Groundwater system in the Chimacum Creek Basin and surface water/ground water interaction in Chimacum and Tarboo Creeks and the Big and Little Quilcene Rivers, Eastern Jefferson County, Washington: U.S. Geological Survey Scientific Investigations Report 2004-5058, 49 p. URL: http://water.usgs.gov/pubs/sir/2004/5058/pdf/SIR2004 5058.pdf, accessed June 2005.

Sherer, B.M., Miner, J.R., Moore, J.A., and Buckhouse, J.C., 1992, Indicator bacteria survival in stream sediments: Journal of Environmental Quality, v. 21, p. 591-596.

Smith, M.S., Thomas, G.W., White, R.E., and Ritonga, D., 1985, Transport of Escherichia coli through intact and disturbed soil columns: Journal of Environmental Quality, v. 14, p. 87-91.

Tesoriero, A.J., Liebscher, H., and Cox, S.E., 2000, Mechanism and rate of denitrification in an agricultural watershed: Electron and mass balance along groundwater flow paths: Water Resources Research, v. 36, p. 1545-1559.

U.S. Department of Agriculture, 1992, Soil Survey of Whatcom County area, Washington: Soil Conservation Service, $481 \mathrm{p}$.

U.S. Environmental Protection Agency, 2002, DraftImplementation guidance for ambient water quality criteria for bacteria, May 2002: Washington D.C., EPA-823-B-02003, p. 90 (Available at http://www.epa.gov/waterscience/ standards/bacteria/bacteria.pdf)

Vogel, J.C., Talma, A.S., and Heaton, T.H.E., 1981, Gaseous nitrogen as evidence for denitrification in ground water: Journal of Hydrology, v. 59, p. 191-200.

Watershed Sciences, LLC, 2002, Aerial Remote Sensing Surveys in the Nooksack River Basin: Thermal Infrared and Color Videography: Corvallis, Oregon, $20 \mathrm{p}$.

Winter, T.C., LaBaugh, J.W., and Rosenberry, D.O., 1988, The design and use of a hydraulic potentiometer for direct measurement of differences in hydraulic head between groundwater and surface water: Limnology and Oceanography, v. 33. no. 5. p. 1209-1214.

Whitman, R.L., and Nevers, M.B., 2003, Foreshore sand as a source of Escherichia coli in nearshore water of a Lake Michigan beach: Applied and Environmental Microbiology, v. 69 , p. 5555-5562. 
Table 1. Ground-water and surface-water quality data for samples collected at the Nooksack River near Everson, lower Nooksack River basin, Whatcom County, Washington, February 2003 to September 2004.

[Abbreviations: col/100 mL, Colony forming unit per 100 milliliters; $\mu \mathrm{S} / \mathrm{cm}$, microsiemen per centimeter at $25^{\circ} \mathrm{C} ;{ }^{\circ} \mathrm{C}$, degrees Celsius; mg/L, milligram per liter; <, less than; >, greater than; -, no data]

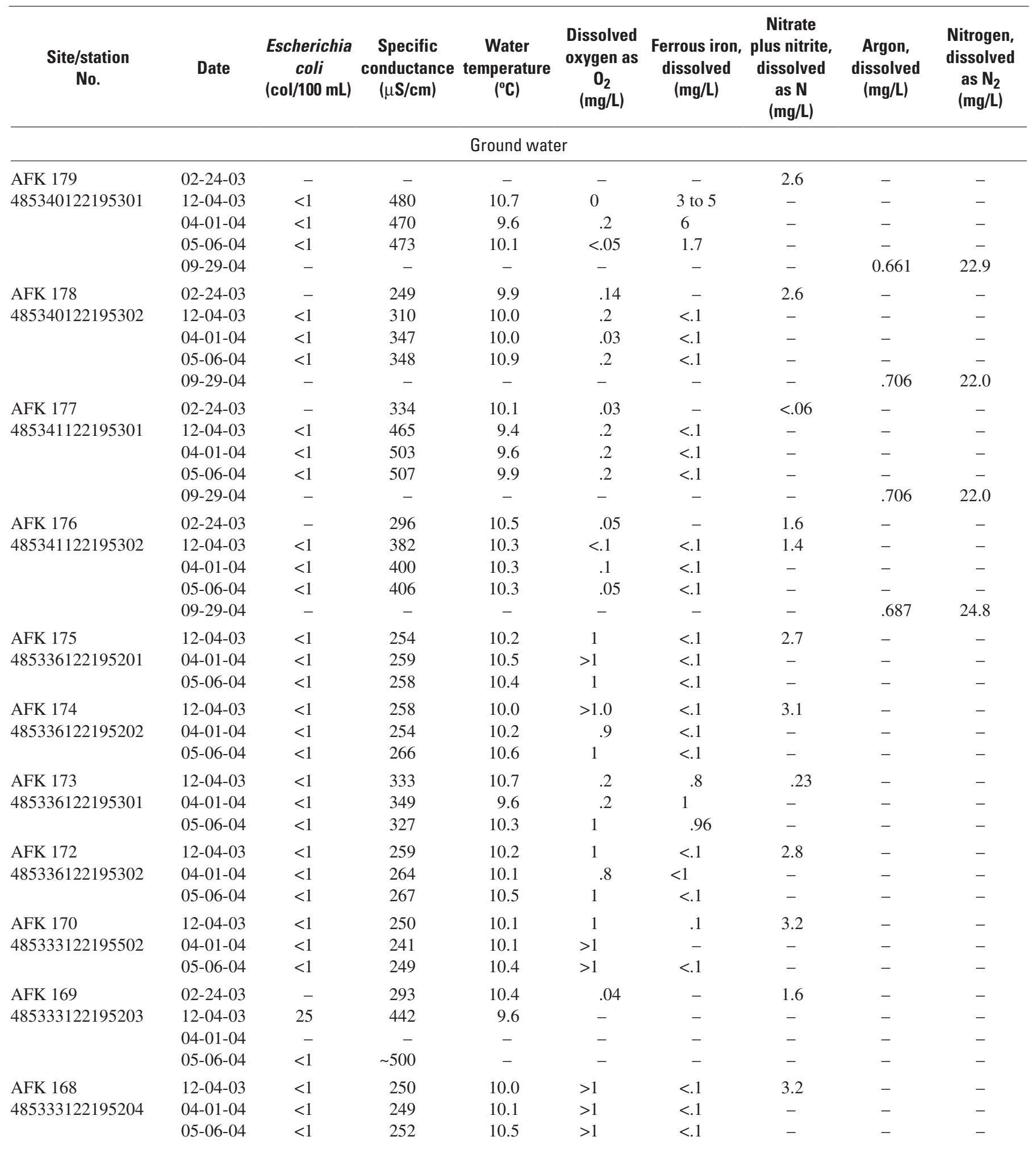


Table 1. Ground-water and surface-water quality data for samples collected at the Nooksack River near Everson, lower Nooksack River basin, Whatcom County, Washington, February 2003 to September 2004.-Continued

[Abbreviations: col/100 mL, Colony forming unit per 100 milliliters; $\mu \mathrm{S} / \mathrm{cm}$, microsiemen per centimeter at $25^{\circ} \mathrm{C}$; ${ }^{\circ} \mathrm{C}$, degrees Celsius; mg/L, milligram per liter; <, less than; >, greater than; -, no data]

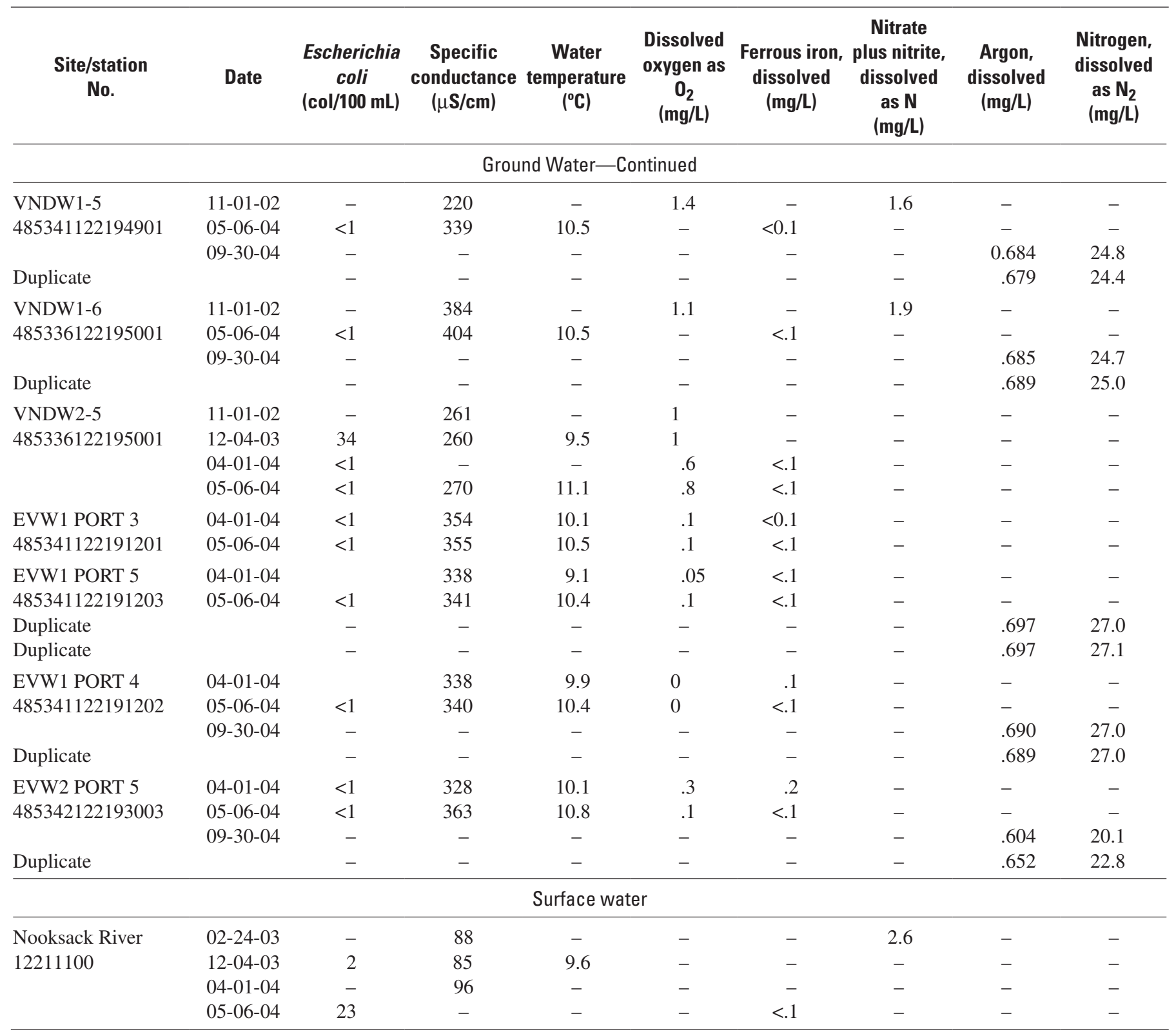


Table 2. Ground-water and surface-water quality data for samples collected at Fishtrap Creek, lower Nooksack River basin, Whatcom County, Washington, October 2003 to September 2004.

[Abbreviations: col/100 mL, Colony forming unit per 100 milliliters; $\mu \mathrm{S} / \mathrm{cm}$, microsiemen per centimeter at $25^{\circ} \mathrm{C} ;{ }^{\circ} \mathrm{C}$, degrees Celsius; mg/L, milligram per liter; RB, Right bank; LB, Left bank; CTR, Thalweg; <, less than; >, greater than; -, no data]

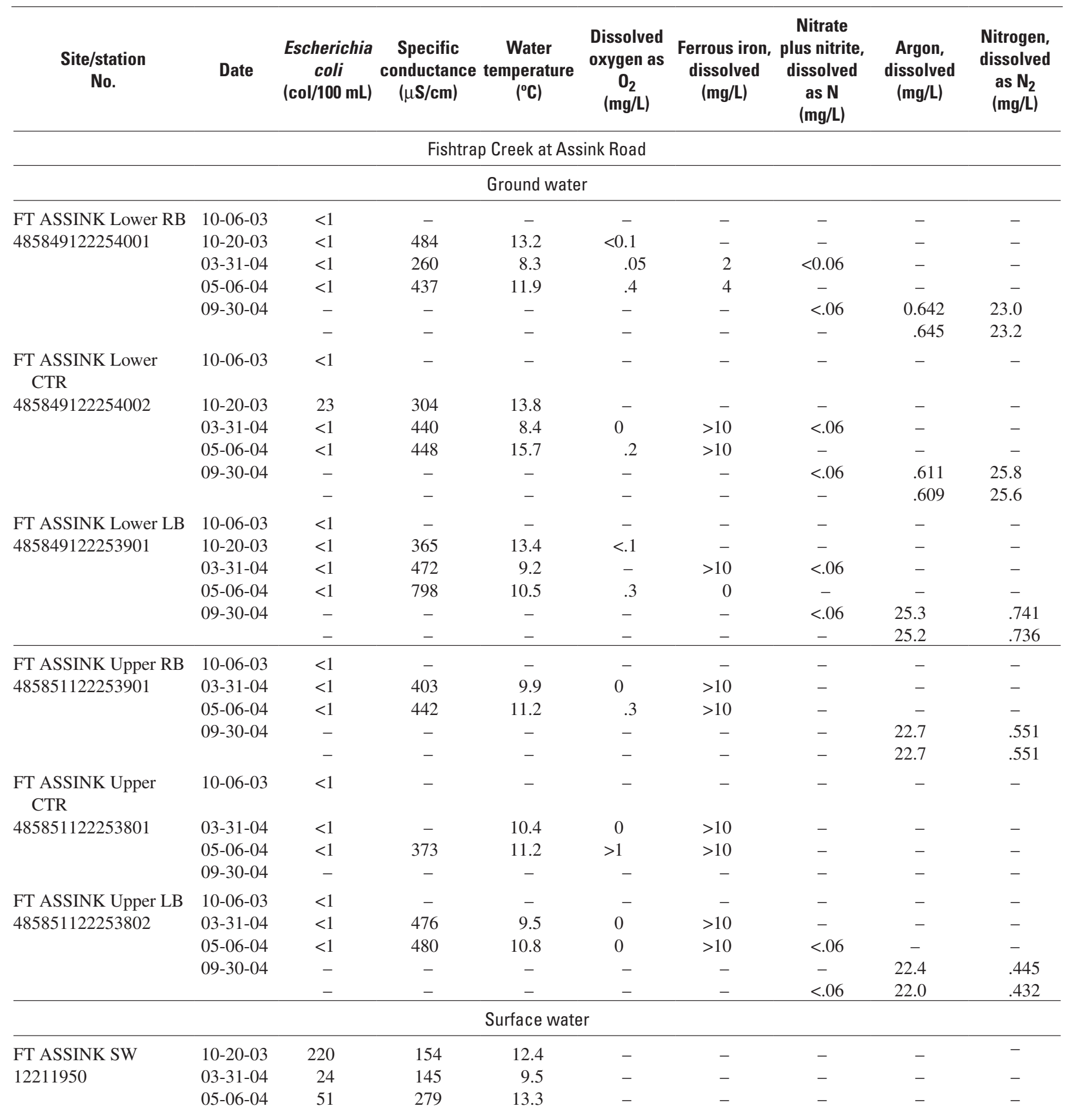


Table 2. Ground-water and surface-water quality data for samples collected at Fishtrap Creek, lower Nooksack River basin, Whatcom County, Washington, October 2003 to September 2004.-Continued

[Abbreviations: col/100 mL, Colony forming unit per 100 milliliters; $\mu \mathrm{S} / \mathrm{cm}$, microsiemen per centimeter at $25^{\circ} \mathrm{C}$; ${ }^{\circ} \mathrm{C}$, degrees Celsius; mg/L, milligram per liter; RB, Right bank; LB, Left bank; CTR, Thalweg; <, less than; >, greater than; -, no data]

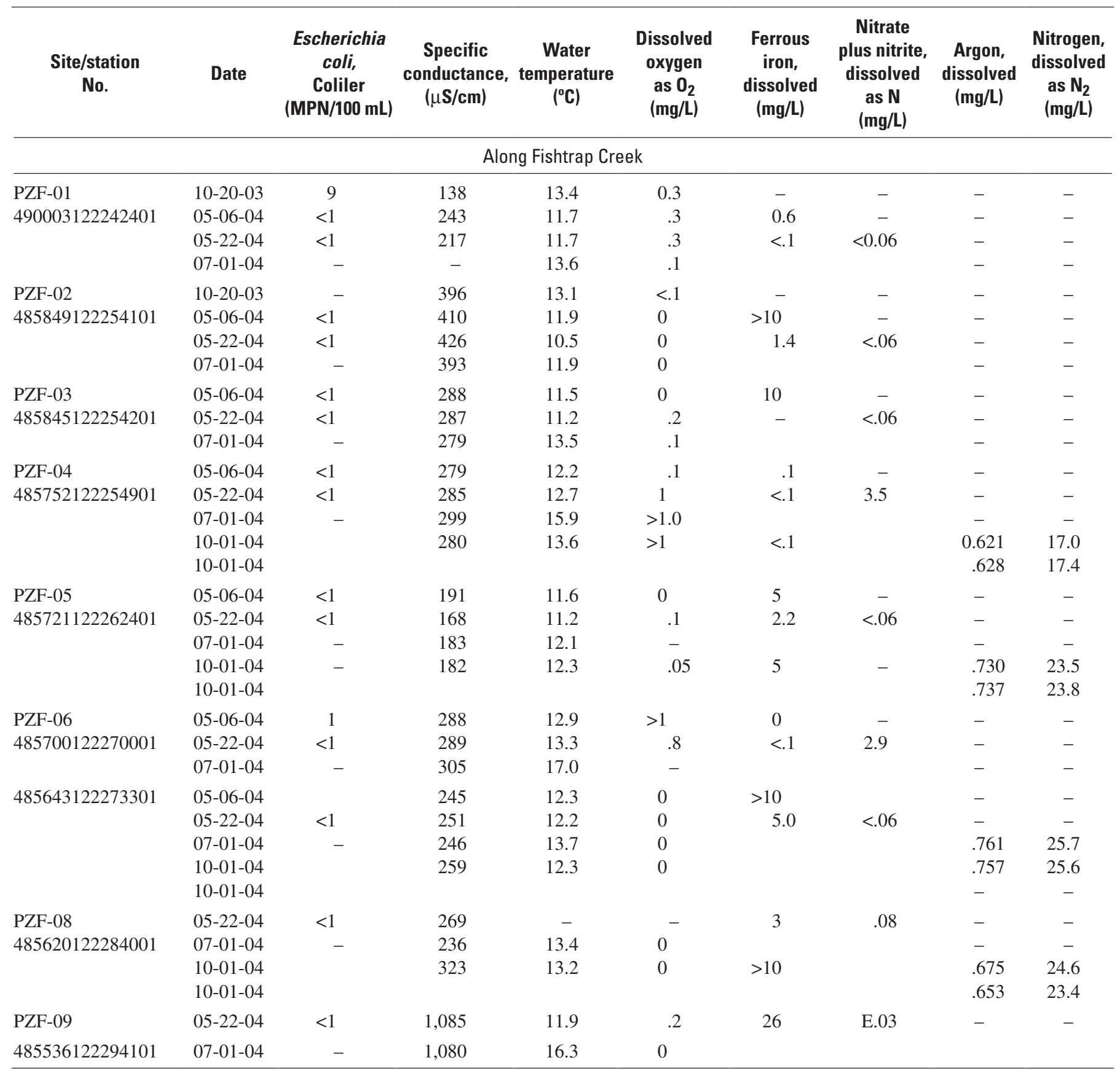


Table 3. Ground-water and surface-water quality data for samples collected at Fourmile Creek, lower Nooksack River basin, Whatcom County, Washington, March 2004 to October 2005.

[Abbreviations: col/100 mL, Colony forming unit per 100 milliliters; $\mu \mathrm{S} / \mathrm{cm}$, microsiemen per centimeter at $25^{\circ} \mathrm{C}$; ${ }^{\circ} \mathrm{C}$, degrees Celsius; mg/L, milligram per liter; <, less than; >, greater than; -, no data]

\begin{tabular}{|c|c|c|c|c|c|c|c|c|c|}
\hline $\begin{array}{l}\text { Site/station } \\
\text { No. }\end{array}$ & Date & $\begin{array}{c}\text { Escherichia } \\
\quad \text { coli } \\
(\text { col } / 100 \mathrm{~mL})\end{array}$ & $\begin{array}{c}\text { Specific } \\
\text { conductance } \\
(\mu \mathrm{S} / \mathrm{cm})\end{array}$ & $\begin{array}{c}\text { Water } \\
\text { temperature } \\
\left({ }^{\circ} \mathrm{C}\right)\end{array}$ & $\begin{array}{c}\text { Dissolved } \\
\text { oxygen as } \mathrm{O}_{2} \\
\text { (mg/L) }\end{array}$ & $\begin{array}{l}\text { Ferrous iron, } \\
\text { dissolved } \\
\text { (mg/L) }\end{array}$ & $\begin{array}{c}\text { Nitrate } \\
\text { plus nitrite, } \\
\text { dissolved as N } \\
\text { (mg/L) }\end{array}$ & $\begin{array}{l}\text { Argon, } \\
\text { dissolved } \\
\text { (mg/L) }\end{array}$ & $\begin{array}{c}\text { Nitrogen, } \\
\text { dissolved } \\
\text { as } \mathrm{N}_{2} \\
(\mathrm{mg} / \mathrm{L})\end{array}$ \\
\hline \multicolumn{10}{|c|}{ Ground water } \\
\hline FMPZ-1 & 03-30-04 & $<1$ & 743 & 9.8 & $<0.05$ & $>10$ & - & - & - \\
\hline \multirow[t]{2}{*}{485223122282501} & $05-06-04$ & $<1$ & 794 & 13.3 & - & - & - & - & - \\
\hline & $10-25-05$ & - & 1,400 & 10.5 & $<.05$ & $>10$ & $<.06$ & 0.243 & 24.0 \\
\hline Duplicate & & - & - & - & - & - & - & .245 & 24.2 \\
\hline FMPZ-2 & $03-30-04$ & $<1$ & 1,400 & 9.8 & .2 & .1 & - & - & - \\
\hline \multirow[t]{3}{*}{485223122282502} & 05-06-04 & $<1$ & 1,400 & 13.2 & .2 & - & - & - & - \\
\hline & $05-28-04$ & - & 739 & 12.5 & .2 & - & $<.06$ & - & - \\
\hline & 06-04-04 & $<1$ & 630 & 16.2 & - & - & $<.06$ & - & - \\
\hline \multirow[t]{4}{*}{485223122282503} & 05-06-04 & $<1$ & 1,400 & 12.5 & .1 & - & - & - & - \\
\hline & $05-28-04$ & - & 1,400 & 12.5 & $<.05$ & - & $<.06$ & - & - \\
\hline & 06-04-04 & $<1$ & 1,400 & 13.1 & - & - & $<.06$ & - & - \\
\hline & $10-25-05$ & - & 2,100 & 10.8 & .1 & .2 & $<.06$ & .751 & 24.1 \\
\hline FMPZ-4 & 03-30-04 & $<1$ & 310 & 9.5 & .3 & .2 & - & - & - \\
\hline \multirow[t]{4}{*}{485225122282401} & $05-06-04$ & $<1$ & 347 & 12.8 & - & - & - & - & - \\
\hline & 05-28-04 & - & 344 & 11.8 & $>1.0$ & $<.1$ & $<.06$ & - & - \\
\hline & 06-04-04 & $<1$ & 353 & 14.6 & - & - & $<.06$ & - & - \\
\hline & $10-25-05$ & - & 474 & 11.7 & .1 & .3 & $<.06$ & .542 & 24.7 \\
\hline Duplicate & & - & - & - & - & - & - & .532 & 24.2 \\
\hline FMPZ-5 & 03-30-04 & $<1$ & 247 & 11.0 & .2 & .1 & - & - & - \\
\hline 485225122282402 & $05-06-04$ & $<1$ & 325 & 13.4 & - & - & - & - & - \\
\hline 485225122282403 & $10-25-05$ & - & 324 & 10.1 & .2 & .2 & $<.06$ & .575 & 20.8 \\
\hline \multicolumn{10}{|c|}{ Surface water } \\
\hline \multirow[t]{4}{*}{12212898} & 03-30-04 & $<1$ & 274 & - & - & - & - & - & - \\
\hline & 05-06-04 & 96 & 330 & - & - & - & - & - & - \\
\hline & $05-28-04$ & 34 & 332 & - & - & - & $<0.06$ & - & - \\
\hline & $10-25-05$ & - & 398 & - & - & - & $<.06$ & - & - \\
\hline Duplicate & & - & - & - & - & - & $<.06$ & - & - \\
\hline $\begin{array}{l}\text { 4-mile downstream } \\
\text { tile drain }\end{array}$ & 03-30-04 & $<1$ & - & - & - & - & - & - & - \\
\hline \multirow[t]{3}{*}{485223122282504} & 05-28-04 & - & - & - & - & - & - & - & - \\
\hline & 06-04-04 & 1 & - & - & - & - & - & - & - \\
\hline & $10-25-05$ & - & - & - & - & - & - & - & - \\
\hline $\begin{array}{l}\text { 4-mile upstream tile } \\
\text { drain }\end{array}$ & 03-30-04 & $<1$ & - & - & - & - & - & - & - \\
\hline \multirow[t]{4}{*}{485225122282404} & 05-06-04 & $<1$ & - & - & - & - & - & - & - \\
\hline & $05-28-04$ & - & - & - & - & - & - & - & - \\
\hline & 06-04-04 & dry & - & - & - & - & - & - & - \\
\hline & $10-25-05$ & - & - & - & - & - & - & - & - \\
\hline
\end{tabular}


Table 4. Ground water and surface water quality data for samples collected at the tributary to Bertrand Creek, lower Nooksack River basin, Whatcom County, Washington, September 2003 to October 2004.

[Abbreviations: $\mathrm{col} / 100 \mathrm{~mL}$, Colony forming unit per 100 milliliters; $\mu \mathrm{S} / \mathrm{cm}$, microsiemen per centimeter at $25^{\circ} \mathrm{C}$; ${ }^{\circ} \mathrm{C}$, degrees Celsius; mg/L, milligram per liter; <, less than; >, greater than; -, no data]

\begin{tabular}{|c|c|c|c|c|c|c|c|c|c|}
\hline $\begin{array}{c}\text { Site/station } \\
\text { No. }\end{array}$ & Date & $\begin{array}{c}\text { Escherichia } \\
\text { coli } \\
\text { (col/100 mL) }\end{array}$ & $\begin{array}{c}\text { Specific } \\
\text { conductance } \\
(\mu \mathrm{S} / \mathrm{cm})\end{array}$ & $\begin{array}{c}\text { Water } \\
\text { temperature } \\
\left({ }^{\circ} \mathrm{C}\right)\end{array}$ & $\begin{array}{c}\text { Dissolved } \\
\text { oxygen as } \\
\mathrm{O}_{2} \\
(\mathrm{mg} / \mathrm{L})\end{array}$ & $\begin{array}{l}\text { Ferrous iron, } \\
\text { dissolved } \\
\text { (mg/L) }\end{array}$ & $\begin{array}{c}\text { Nitrate } \\
\text { plus nitrite, } \\
\text { dissolved } \\
\text { as N } \\
\text { (mg/L) }\end{array}$ & $\begin{array}{l}\text { Argon, } \\
\text { dissolved } \\
\text { (mg/L) }\end{array}$ & $\begin{array}{c}\text { Nitrogen, } \\
\text { dissolved } \\
\text { as } \mathrm{N}_{2} \\
\text { (mg/L) }\end{array}$ \\
\hline \multicolumn{10}{|c|}{ Ground water } \\
\hline \multirow{6}{*}{$\begin{array}{l}\text { BERT N.C. } \\
485756122284302\end{array}$} & $10-21-03$ & - & 304 & 13 & $<.1$ & - & - & - & - \\
\hline & $12-04-03$ & $<1$ & 441 & 9 & - & $>10$ & - & - & - \\
\hline & 03-31-04 & $<1$ & 386 & 10 & 0 & $>10$ & - & - & - \\
\hline & $05-07-04$ & $<1$ & 435 & 11 & 0 & $>10$ & - & - & - \\
\hline & $05-27-04$ & $<1$ & 426 & 11 & 0 & - & $<0.06$ & - & - \\
\hline & 06-04-04 & $<1$ & 424 & 15 & 0 & $>10$ & $<.06$ & 0.792 & 24.1 \\
\hline \multirow{7}{*}{$\begin{array}{l}\text { BERT N.E. } \\
485756122284301\end{array}$} & $10-21-03$ & - & 138 & 13 & .2 & - & - & - & - \\
\hline & $12-04-03$ & $<1$ & 418 & 10 & - & $>10$ & - & - & - \\
\hline & 03-31-04 & $<1$ & 436 & 10 & 0 & $>10$ & - & - & - \\
\hline & $05-07-04$ & $<1$ & 483 & 11 & 0 & $>10$ & - & - & - \\
\hline & $05-27-04$ & $<1$ & 471 & 12 & 0 & - & $<.06$ & - & - \\
\hline & 06-04-04 & $<1$ & 475 & 12 & 0 & $>10$ & $<.06$ & .675 & 23.5 \\
\hline & $10-25-04$ & - & - & - & 0 & - & $<.06$ & .677 & 23.5 \\
\hline \multirow{4}{*}{$\begin{array}{l}\text { BERT N.W. } \\
485756122284303\end{array}$} & 09-30-03 & - & 233 & 14 & .2 & - & - & - & - \\
\hline & $10-06-03$ & 2 & - & - & - & - & - & - & - \\
\hline & $10-21-03$ & & 244 & 13 & .1 & - & - & - & - \\
\hline & $12-04-03$ & $<1$ & 384 & 9 & - & $>10$ & - & - & - \\
\hline \multirow{7}{*}{$\begin{array}{l}\text { BERT C.C. } \\
485755122284302\end{array}$} & $10-21-03$ & & 199 & 13 & $<.1$ & - & - & - & - \\
\hline & $12-04-03$ & $<1$ & 383 & 9 & - & 10 & - & - & - \\
\hline & $03-31-04$ & $<1$ & 445 & 10 & - & - & - & - & - \\
\hline & $05-07-04$ & $<1$ & 373 & 11 & .1 & $>10$ & - & - & - \\
\hline & $05-27-04$ & $<1$ & 686 & 11 & 0 & - & $<.06$ & - & - \\
\hline & 06-04-04 & $<1$ & 357 & 16 & 0 & - & $<.06$ & .685 & 22.3 \\
\hline & $10-25-04$ & - & - & - & 0 & - & $<.06$ & .682 & 22.0 \\
\hline \multirow{9}{*}{$\begin{array}{l}\text { BERT C.W. } \\
485755122284303\end{array}$} & $09-30-03$ & - & 254 & 15 & 0 & - & - & - & - \\
\hline & $10-06-03$ & $<1$ & - & - & - & - & - & - & - \\
\hline & $10-21-03$ & - & 214 & 13 & $<.1$ & - & - & - & - \\
\hline & $12-04-03$ & $<1$ & 411 & 9 & - & $>10$ & - & - & - \\
\hline & $03-31-04$ & $<1$ & 433 & 9 & 0 & $>10$ & - & - & - \\
\hline & $05-07-04$ & $<1$ & 425 & 11 & .1 & $>10$ & - & - & - \\
\hline & $05-27-04$ & $<1$ & - & 11 & 0 & - & $<.06$ & - & - \\
\hline & 06-04-04 & $<1$ & 428 & 14 & 0 & $>10$ & $<.06$ & .715 & 23.9 \\
\hline & $10-25-04$ & - & - & - & 0 & - & $<.06$ & .720 & 24.1 \\
\hline
\end{tabular}


Table 4. Ground water and surface water quality data for samples collected at the tributary to Bertrand Creek, lower Nooksack River basin, Whatcom County, Washington, September 2003 to October 2004._-Continued

[Abbreviations: $\mathrm{col} / 100 \mathrm{~mL}$, Colony forming unit per 100 milliliters; $\mu \mathrm{S} / \mathrm{cm}$, microsiemen per centimeter at $25^{\circ} \mathrm{C} ;{ }^{\circ} \mathrm{C}$, degrees Celsius; $\mathrm{mg} / \mathrm{L}$, milligram per liter; <, less than; >, greater than; -, no data]

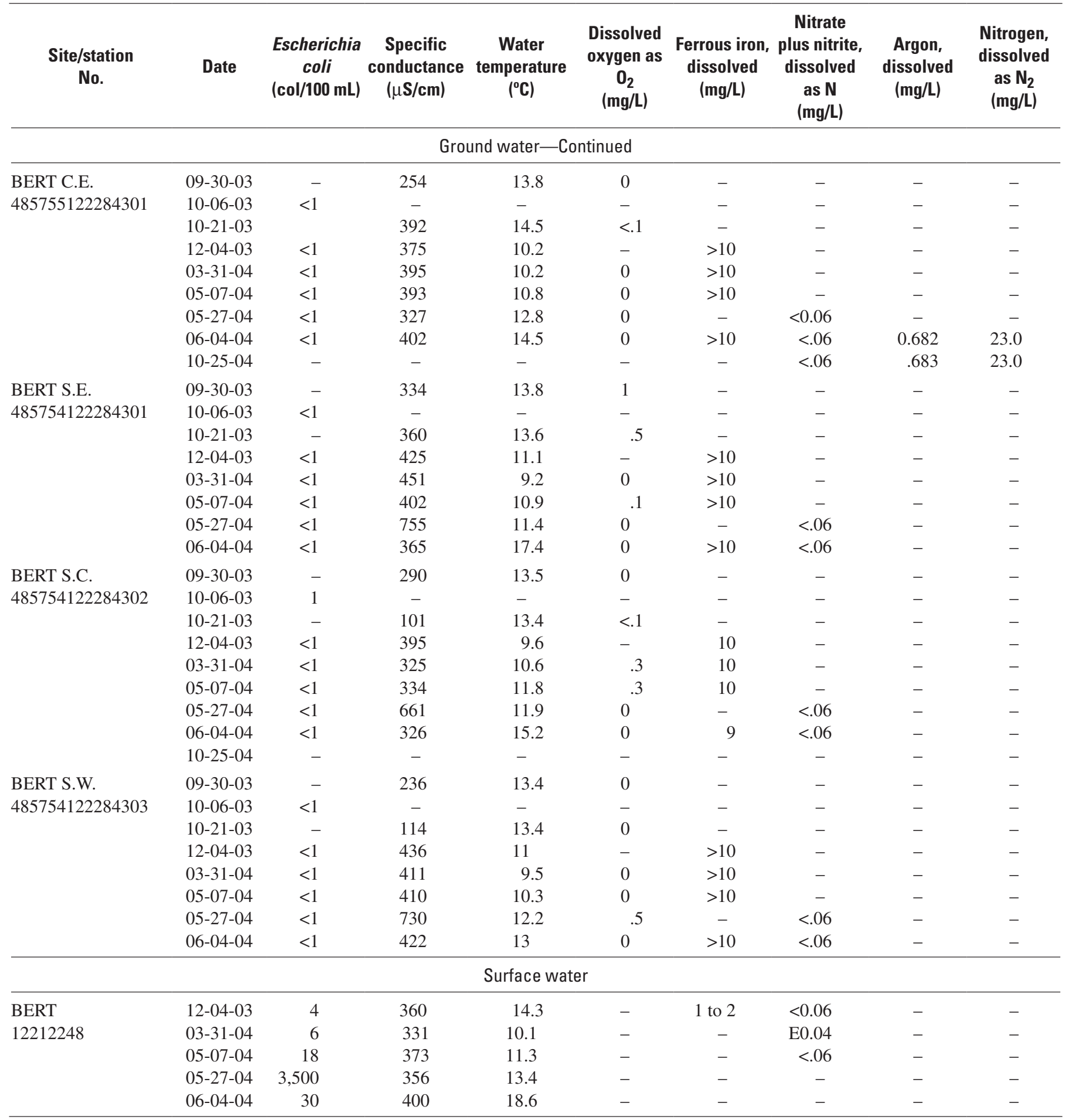


This page left intentionally blank 
Manuscript approved for publication, November 16, 2005

Prepared by the U.S. Geological Survey Publishing staff

Tacoma Publishing Service Center

Bill Gibbs

Linda S. Rogers

Bobbie Richey

For more information concerning the research in this report, contact the Director, Washington Water Science Center

U.S. Geological Survey

1201 Pacific Avenue - Suite 600

Tacoma, Washington 98402

http://wa.water.usgs.gov 
